University of Louisville

ThinkIR: The University of Louisville's Institutional Repository

Electronic Theses and Dissertations

1942

\title{
The effect of pigments on oleoresinous film structure.
}

Glenn Robert Eudaley 1920-

University of Louisville

Follow this and additional works at: https://ir.library.louisville.edu/etd

Part of the Mechanical Engineering Commons

\section{Recommended Citation}

Eudaley, Glenn Robert 1920-, "The effect of pigments on oleoresinous film structure." (1942). Electronic Theses and Dissertations. Paper 2045.

https://doi.org/10.18297/etd/2045

This Master's Thesis is brought to you for free and open access by ThinkIR: The University of Louisville's Institutional Repository. It has been accepted for inclusion in Electronic Theses and Dissertations by an authorized administrator of ThinkIR: The University of Louisville's Institutional Repository. This title appears here courtesy of the author, who has retained all other copyrights. For more information, please contact thinkir@louisville.edu. 
mr VI:

T2E EFFE⿱

\section{A. Theselo}

Subal ted to the Foulty

of the Gradunte sohool

of the Iniveratty of Loulav1lle

In Partial sulnilluat

of the requl roments

for the of of

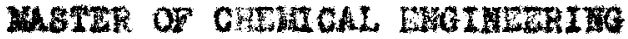

Depurtment of chemleal Englnearing

By

QLenn Robert Etadeloy Jr.

1942. 


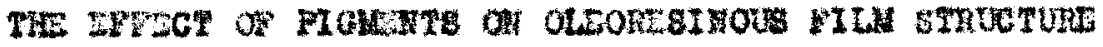

Glem Hobert Eudaloy Jr.

Approwed by the Bramining Gowal teet

Dis rootor

14y 14. 1942 . 
TABLE: O ConTars

Puse

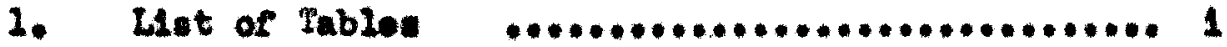

2. Llet of PLguren $\ldots \ldots \ldots \ldots \ldots \ldots \ldots \ldots \ldots \ldots \ldots \ldots \ldots \ldots \ldots \ldots \ldots$ 11

3. Aolonowlodgment $\ldots \ldots \ldots \ldots \ldots \ldots \ldots \ldots \ldots \ldots \ldots \ldots \ldots \ldots \ldots \ldots$ v

4. Abotraot $\ldots \ldots \ldots \ldots \ldots \ldots \ldots \ldots \ldots \ldots \ldots \ldots \ldots \ldots \ldots+v$

B. Introdustlon $\ldots \ldots \ldots \ldots \ldots \ldots \ldots \ldots \ldots \ldots \ldots \ldots \ldots \ldots \ldots \ldots, 1$

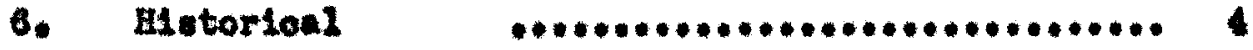

7. Thooretionl $\ldots \ldots \ldots \ldots \ldots \ldots \ldots \ldots \ldots \ldots \ldots \ldots \ldots \ldots 12$

8. Exporimental

Raw Materials

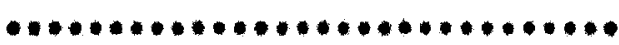

Apparatus

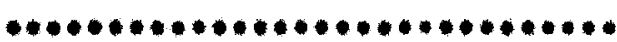

Prooedure

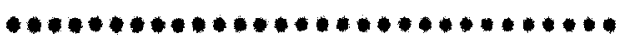

Resulte

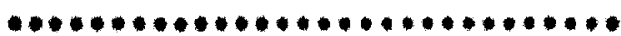

40

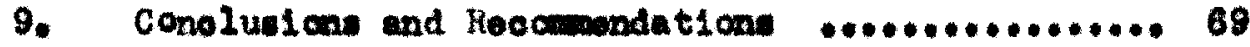

10. Appendix

Li torature Cstod

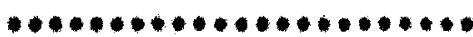

Acknowledgmonte

$\bullet \bullet \bullet \bullet \bullet \bullet \bullet \bullet \bullet \bullet \bullet \bullet \bullet \bullet \bullet+\bullet \bullet \bullet \bullet$

76

Vita

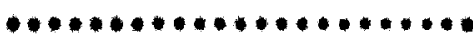




\section{LI8T OP TABLE}

Table

Page

I Ename1 Formulations

26

11 Physical Froperties of Typleal Bnamel

Formulati one te Varyling Ages ................ 4s

III Fhystoul Properties or All Film at

Ten Gyoles Age ........................... 51 
Lres of Foures

PEure

Page

2 Casting $111 \mathrm{x}$ an th panel with doetar blade ........ 28

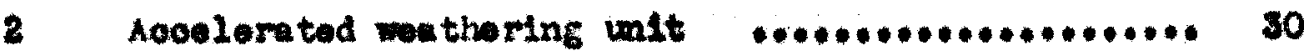

8 Herometer $\ldots \ldots \ldots \ldots \ldots \ldots \ldots \ldots \ldots \ldots \ldots \ldots \ldots \ldots \ldots \ldots \ldots \ldots \ldots \ldots \ldots, 38$

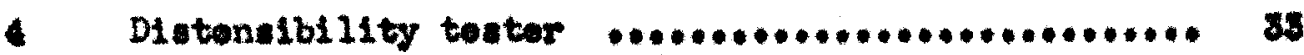

5 Sextruotion butteries $\ldots \ldots \ldots \ldots \ldots \ldots \ldots \ldots \ldots \ldots \ldots \ldots \ldots \ldots \ldots \ldots$ s5

6 Volwa Poroont Dnoxtraotablo v. As and Slcagntica

for 16 gullen Lineeod 011-Diblite Varnish of th

ono-half the Resin Repleoed by Titaniu DIaxide w..... 4

7 Volus Perosnt Unoxtruatable ve. Age and Elongatica

for 16 gellon turs OLI-Bake 21 to Varnioh with

onowhalf the Rouln Replaoed by Baslo Loud Carbonat .. 45

8 Volum Peroont Dnextructable ve. Age for 16 gallan

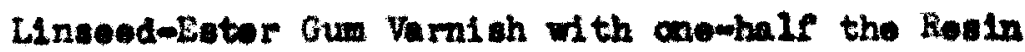

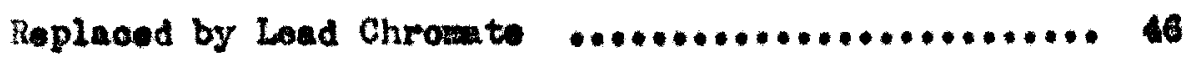

- Volue Percent Unextraotable ve. Age for 16 gellan

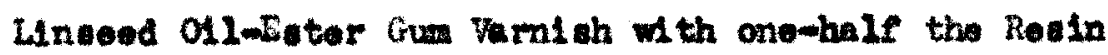

Repleoed by Iron Oxide $\ldots \ldots \ldots \ldots \ldots \ldots \ldots \ldots \ldots \ldots \ldots \ldots \ldots \ldots$

10 Volue Percent Choxtraotable ve. Age and Slongation

for 33 gallon Linged OL-Eater Gun Varnish wh

onemalf the Resin hepleoed by IItaniun DIoxide...... 
LIST OF PIGURES (oontinued)

Figure

11 Volum Poroent thextruotable ve. A6e and Elengation

for 38 gallon Inneed oll-bilall to Varnich Wth

anombif the Rosin Roplaowd by Laed Carbonato ......... 48

12 Volum Peroent thextraotable ve. Peroont of Plas in

Foplaoed by Flamont for 16 gllon Linged 011-ister

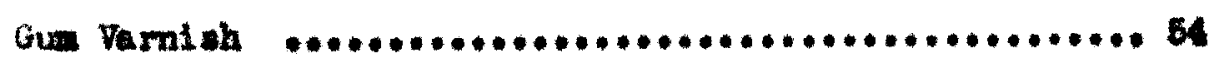

15 Volum Poroont Dhextruotible ve. Proont of pealn

Replaoed by PLgment for 33 gallon Linseod 012-antor

ou Varnt oh

14 Voluw Peroent Unextraotable va. Poroent of Resin

iloplaced by Plgment for 16 gallon Linsed oll-Bakellto

Vurniteh $\ldots \ldots \ldots+\ldots \ldots \ldots \ldots \ldots \ldots \ldots \ldots \ldots \ldots \ldots \ldots \ldots \ldots \ldots \ldots$

15 Volum Peroent Unoxtraotable ve. Peroent Resin

Heplaoed by Plewent for 33 gallon Lineeodmbakalite

Varnioh

16 Volum Poroent Dnoxtraotable ve. Foroent of llesin

Roplaoed by Plgment for 16 gallon Castor 011-inkelito

Varnish

62

17 Volum Purcent hextruotable ro. Peroent of Resia

Ropleoed by Plgment for $16 \mathrm{gallom}$ Tung 011-Bakel1te

Varnish 


\section{LIST RIOWES (oontinuad)}

Figure

Page

18 Volue Poroent thoxtraotablo VB. Porount of Rosin Replacod by It tantum Dionside ค.................

19 Volum Peroent thextrastable vi, Paroent of Rosin Roplaoud by Baslo Jand Carbonate $\ldots \ldots \ldots \ldots \ldots \ldots \ldots \ldots$

20 Volum Peroont Unoxtraotuble ve. Feroent of Bealn Replaced by Lad Chrom to ..................... 66

22 Volume Peroent Unoxtraotable ve, Percent of kenln Poplaced by Iron oxide 


\section{LCRTOILEDGEAT}

The Auther wl she to aolonowledge the

Kad assiatanoe and helpful guldanoe

of Doctor R. C. Ernat, who

dirooted this researoh. 


\section{Abstance}

The purpoes of this Inventigation is to determin: the

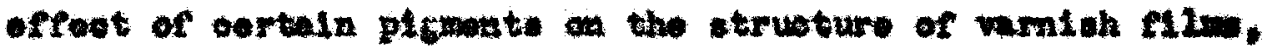

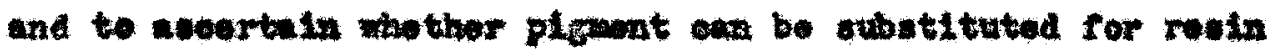
In the formulation of aleorocinom coutingo.

Enamel: wore proparte by ropladtad different rolume

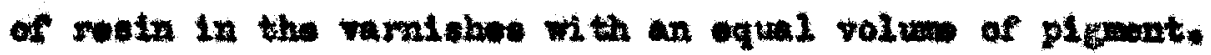

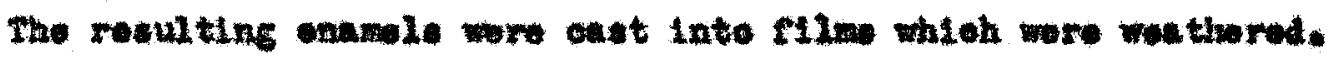

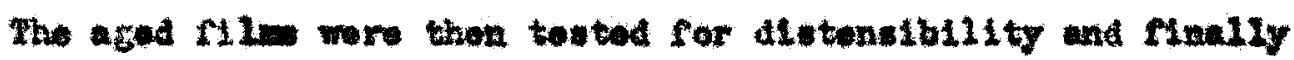
artracted in th noetrop.

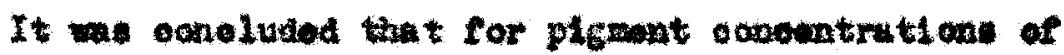

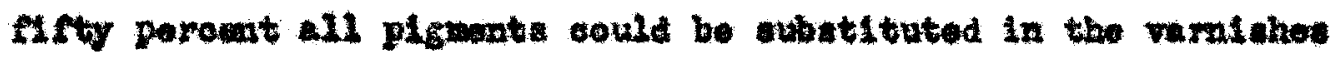

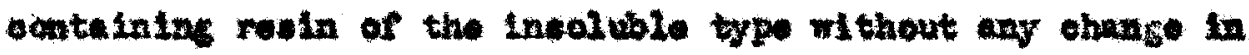

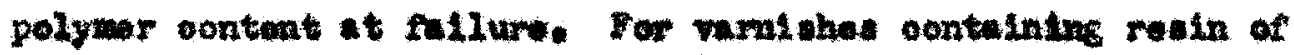
tho ablublo type this ewbotitution wa ong posible for

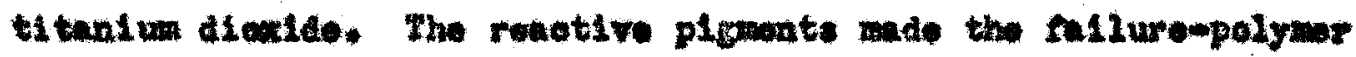
Inoroube lato the ragge of the incoluble rouln type veminhes.

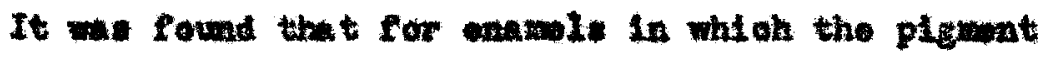

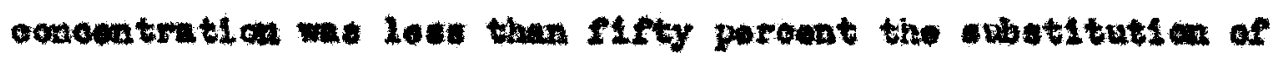
pigant for reatn ouned bbrupt doerenese in the vilue of the polymor eontent at fullure. This wa attributad to the fact that

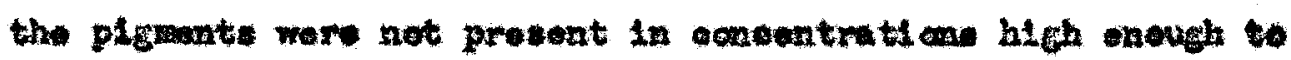
andiblt thele true effect. 
I I O O U C I Ox 


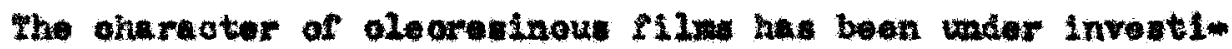
gatton $(4,5)$ In thi Laboratory for sovorel youra. It hes boon ostab-

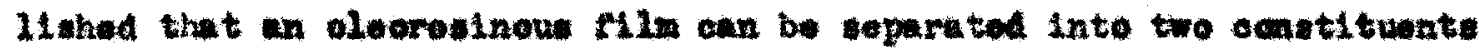

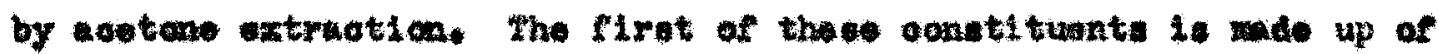

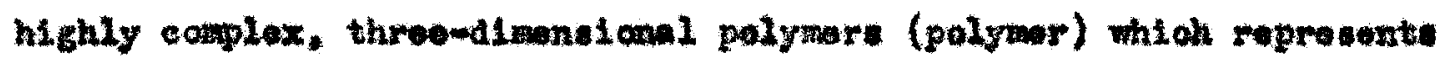

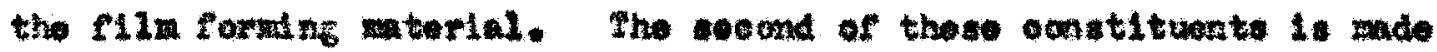

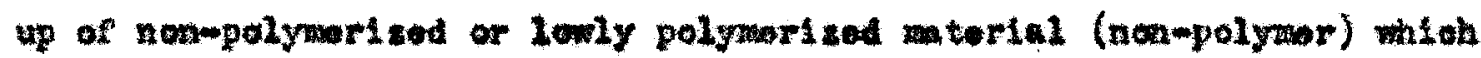

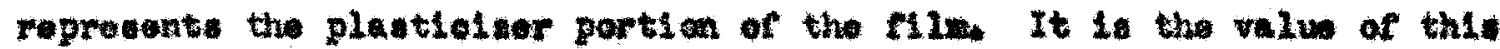

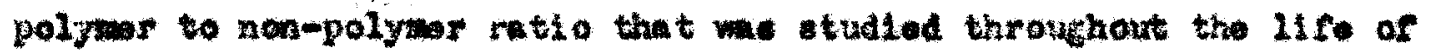
the 112 .

The previou investictore $(4,5)$ foud thet the ral we of

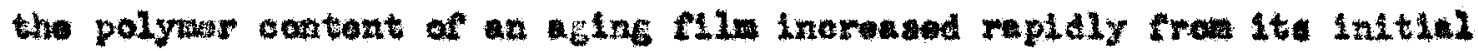

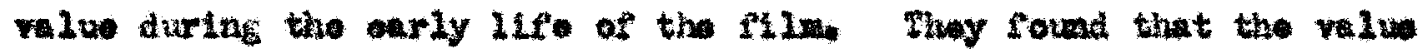

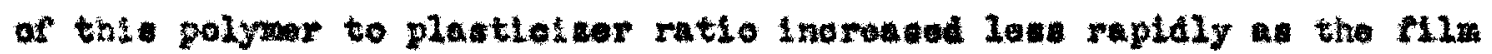

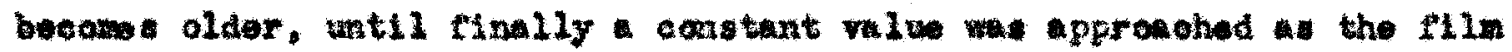
nowrod fallure.

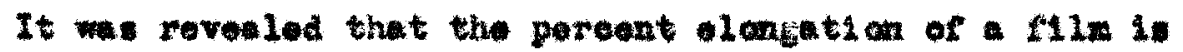

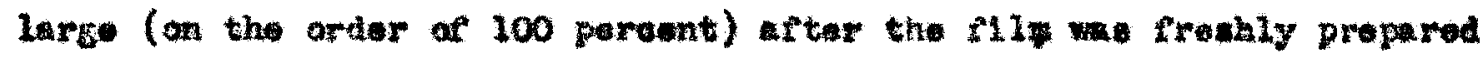

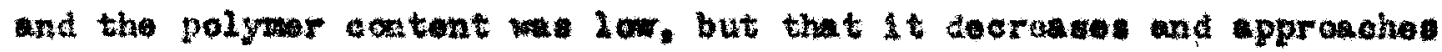

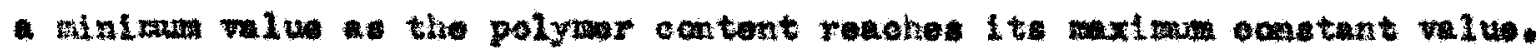

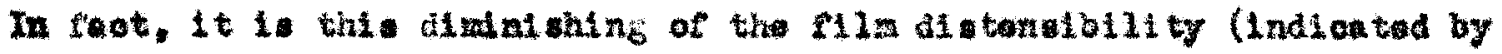
the poreoxt alongtion) that oause the fill to foll. 
The oxporiventel rork up to thi tim has conddered, prinolpally, clear varmishos. It is the purpose of this invostiog-

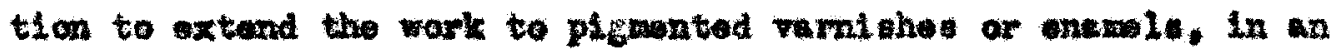
effort to dotermine tha effect of pignents on tho varalches that

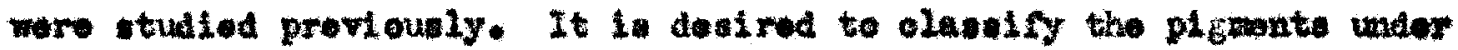
conoldaration acoording to their polymorleatia efreate. as the provlous invoatigatore (4) did for rasibs. This work is to bo don

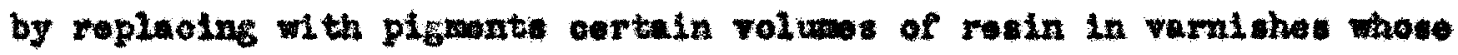

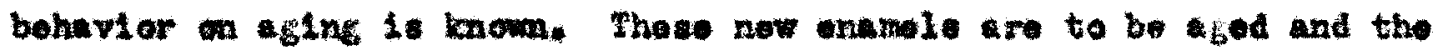
valus of the polymor contont and the perount elonghtion aro to bo determinad durins the 11 fe of the film. These now values wil then

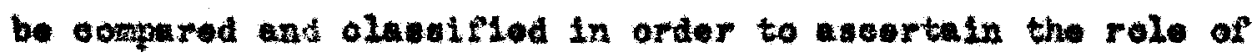

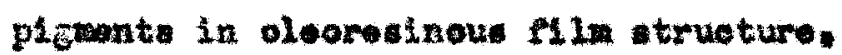




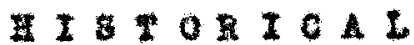


It I. wall know that the tur of a plant preant in a paint has a dintinot influenos upon the rate of drying of the palnt and upon the oharecteristion of the film obtained after arying.

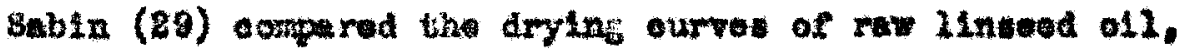

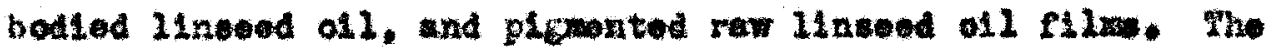

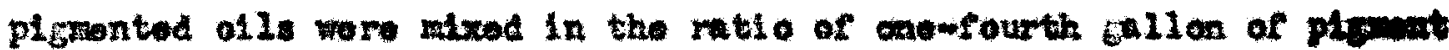
to throp-fourthe gillon of all. He found the the aurvat of tho plewented oll and the raw ofl filme followod the genoral trend

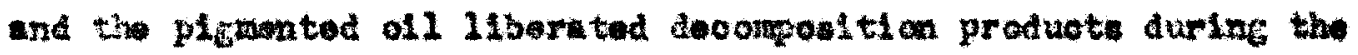
ontire yertod of arying. If further obeerved that the ohange in wolght udergone by a palnt fliw durlat drying depended as the nature of the plgwont prowent in the paint.

Gardrev (6) postulated tile avolution of arganto nota of

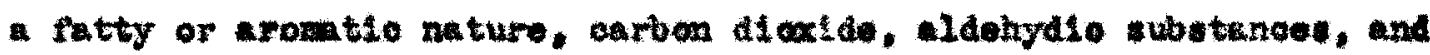
11. obserred that balie plobanted flw were woro notive in this ropoot. Alu (9) inveatiged the evolution of volatile products

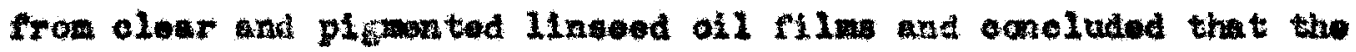

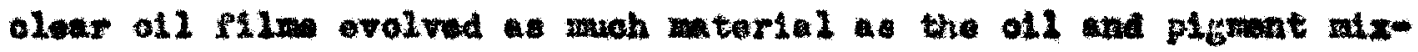
thare.

Whodes and Ven Wirt (27) investignted the effoot of varlow

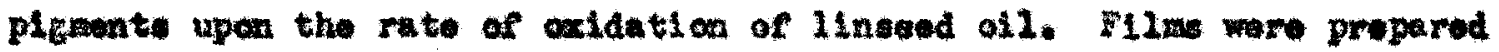

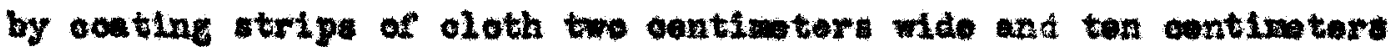
lons wh the lineeth ofl paint that oontained 0.2 peroent load drier 


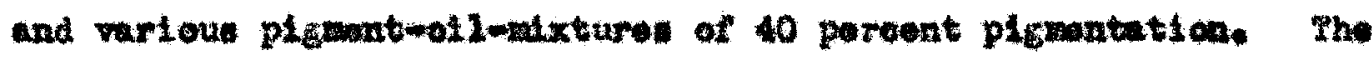

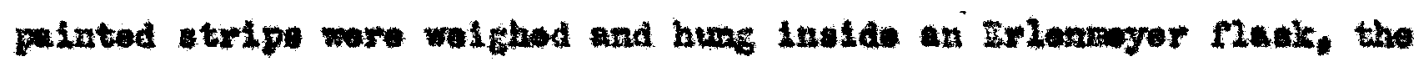
alr was displaced with oxygon, and the rlank mas comoeted to a manoweter in swah annor the difforoned in lovelo gave a monure of the oxyses mberbod. Hy resoring the oloth otripe and rewolghing thom, it was posalblo to oulowat tho appuront lose in weight diw to volatlle product:

They (27) conoluded that the dryine of lineoed ofl wos on

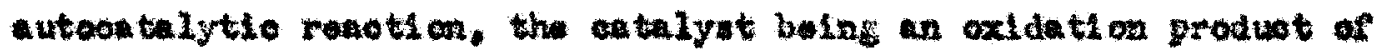
the all 1tavli. Thoy further ooneluded that the woll-momn effeot of loed sults in aoolerating the drylne of oll is du to the fuot

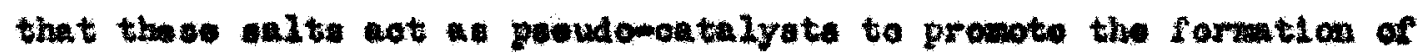
sutoentalysto and thus inorease the oxidation rate.

Whodes and Ven firt divided pignent: into throe groupw. The firet of these, of whioh ellex it an oxaple, had lietle or no arfoot on the oxidation of the film inveatigatod. Tho socond group.

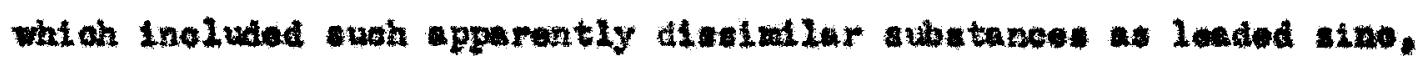

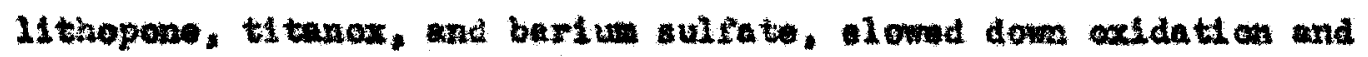

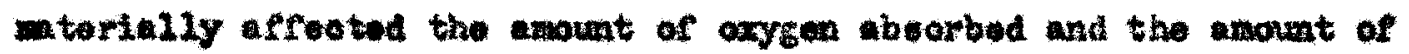
voletile mater siven off. The third group of plononts included thow whish tend to ineroane the anougt af oxygen absorbed by the ofl

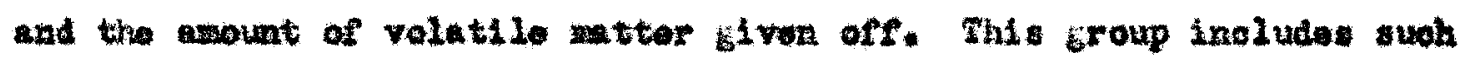

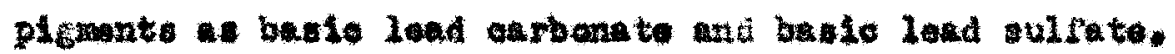




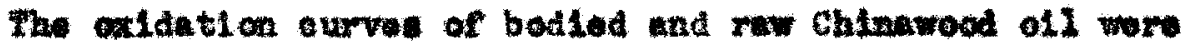

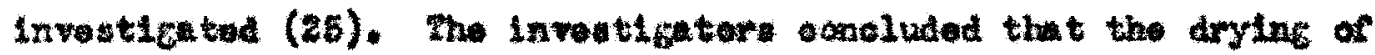

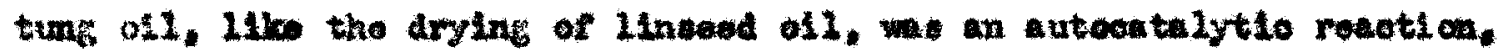

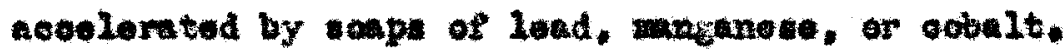

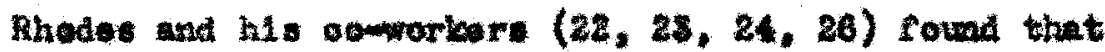

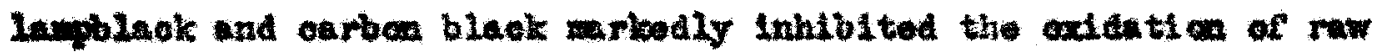

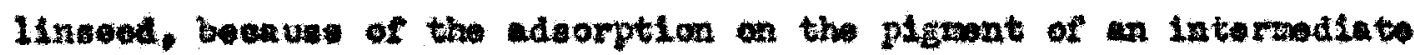

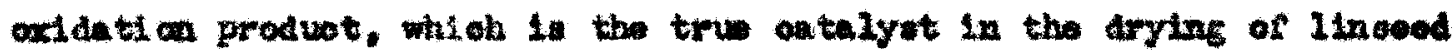

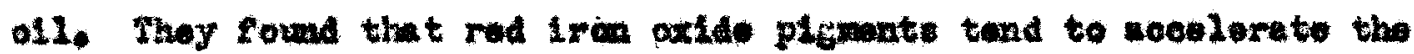

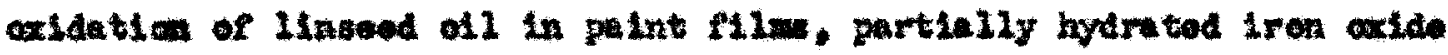

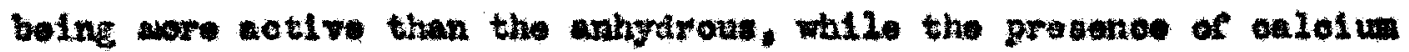

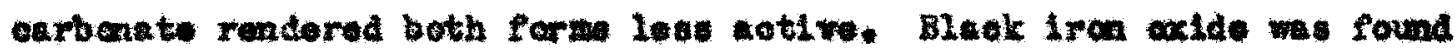
to be relativaly inort, retarding $11 \mathrm{ghthy}$ the oxidation of the ofl. zino oxtde (pure) had no orfoet on the oxldation rate and the

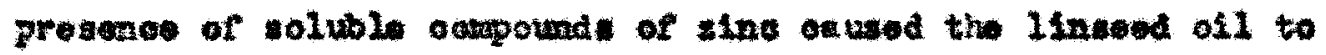

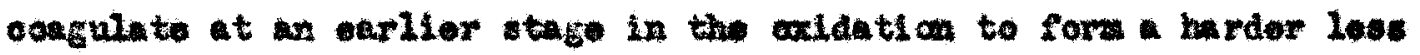

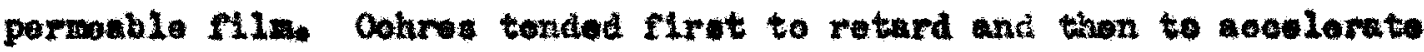
the drylne of tho all. Inltial rotardation wa caued by absorption of

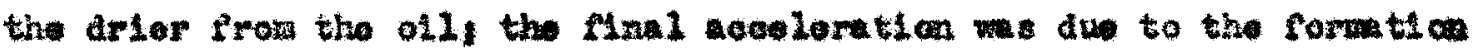

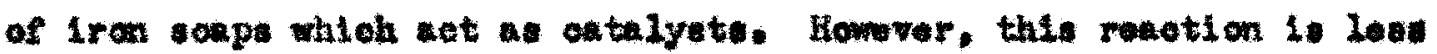
notive than that of rod iron oxds. Steman wad ubere show lasa offoot an the inltial rate of oxidation of the 011 than ald ochre. boonuse the renovil of the latd drier is componsated by the formeton of and1 anount of Innganate drtor. 
Extenatwe work on the structure of oleorenineus filw

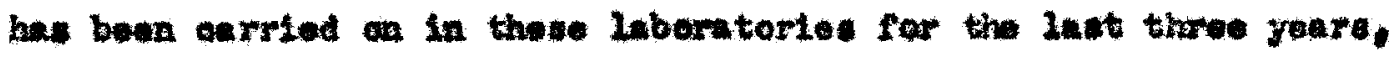
thi: paper belne the third in this aerlos. The initial Inventigatien was onrriod an by Emet and Hodutikia (5). They worked wt varnieh

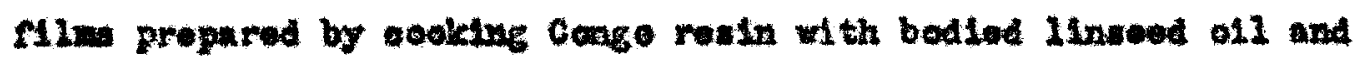
exlorived tung oil in $0,26,26$, and 38 gallon lengthe and onamel films propared by grinding titantum dioxido in the above vamidhos.

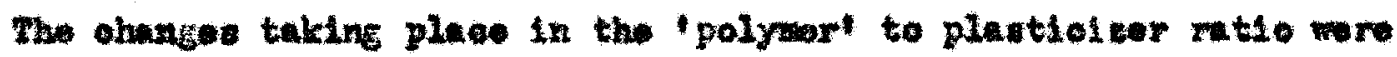

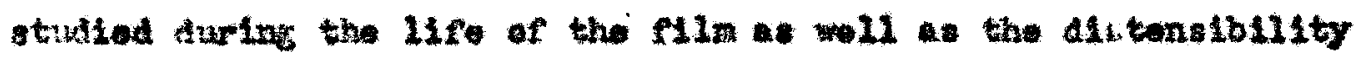

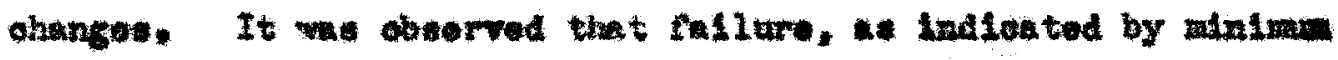
diatenatbility, wourred when the oonentration of the polyor, as

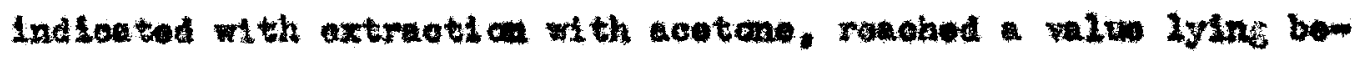
tweon 10-80 pereunt. From these obervations thoy concluded that

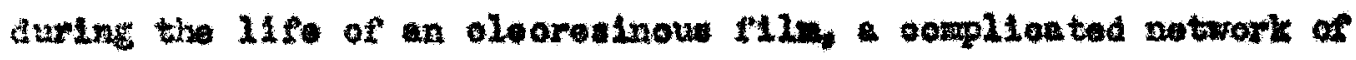

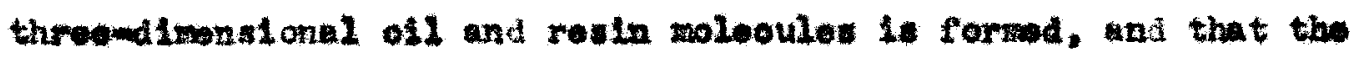
formation of this notwork graduily deoreaves the olatiolity of the Alis until fallure oocurs. They also obsorved that the polymorisatica

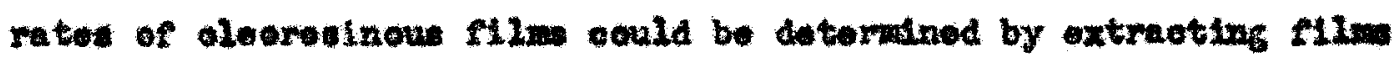

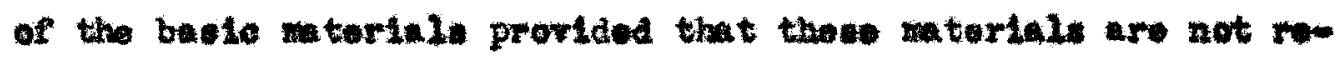
notive.

Th4. fuadamotal rosearoh was oxtonded by firmat and Lubber. (4), oo that it inoluded varnishos formulated from typiond

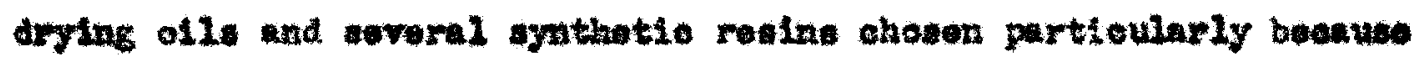




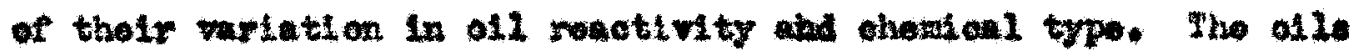

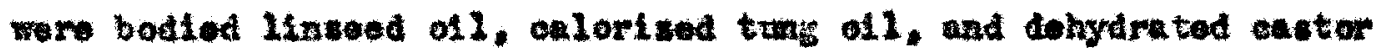

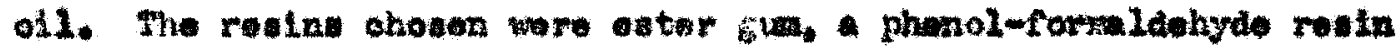

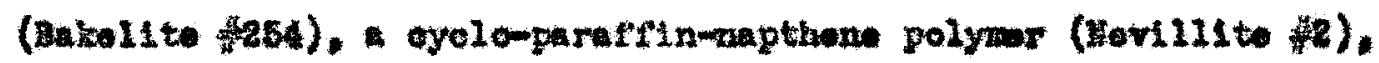

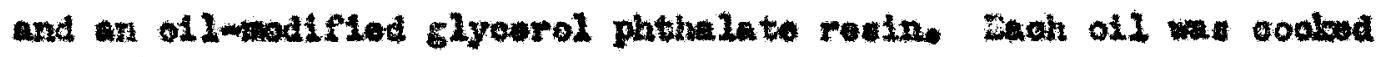

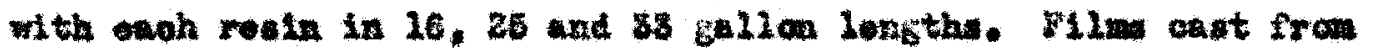
the resulting varnilabo we wathered for suocoalve poriode. - longated, and extruoted with coetcos. The polyal oontent wis correlated wth the go of the rilm and the pareent longtion, and

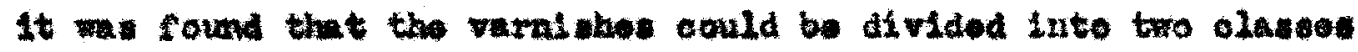
noording to the realn ontained.

The flret olese contalned rosins of the insolublet type.

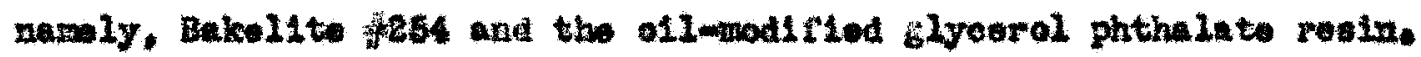
These resing are insoluble in acetan per so, and tand to prosote polymerleation to the wxtont the the value of the polymer oontent at

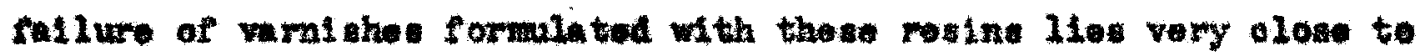

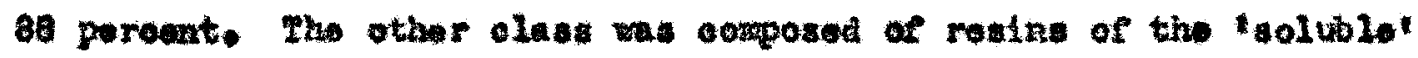

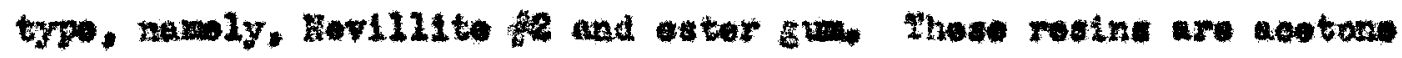

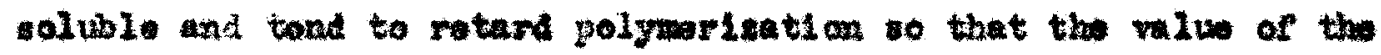
polyour content at fallure of ramiahen formalated with then vartes over folatively larce rang aoectirg to the ofl lensth and the

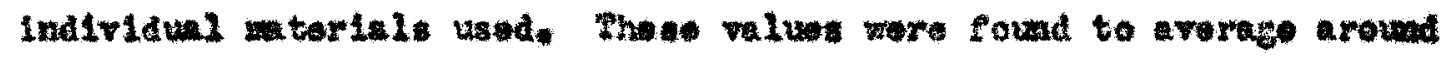
75 perasat. 


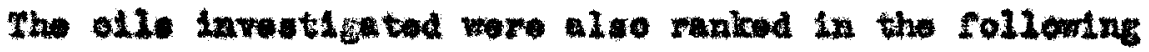

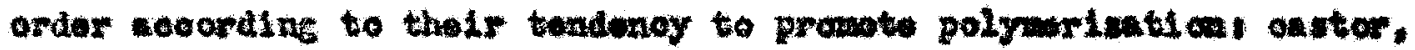

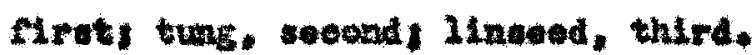

Varione other laventigutore previous to thowe alrouty

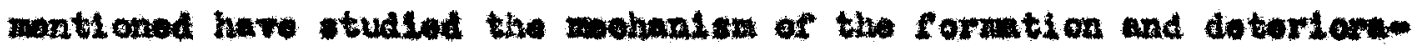

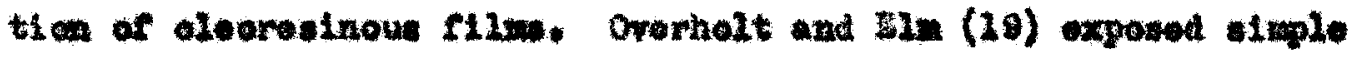

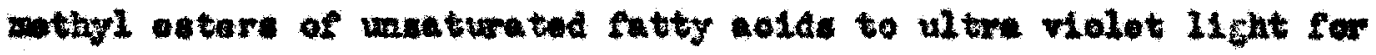

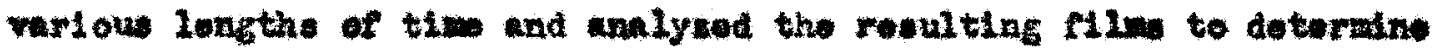

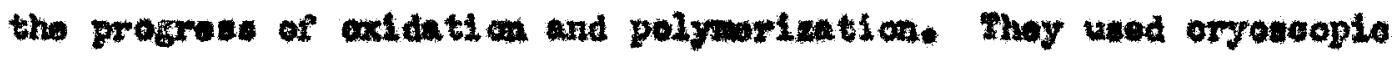

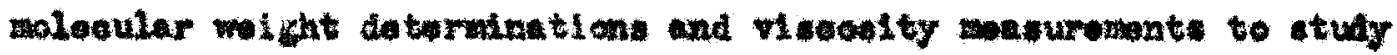

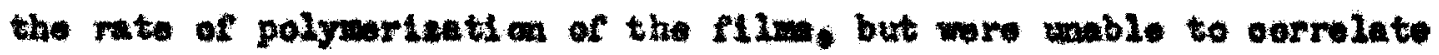
the resulte obtalned by the two mothode. In Intor atulies $(20,21)$

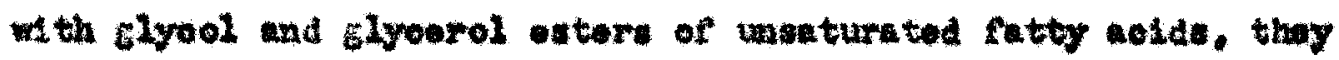
observed that the rat of polymeritation is greater in tho owriler

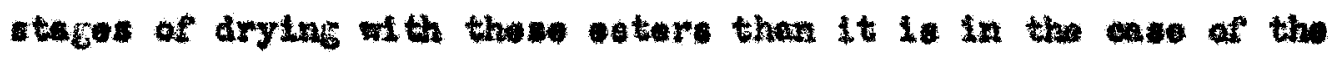
wore Inple ecters.

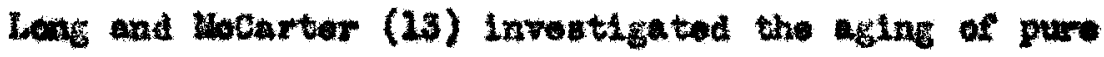
trillnolute and trilnolinte flyourlden, and oonoluded the drytos

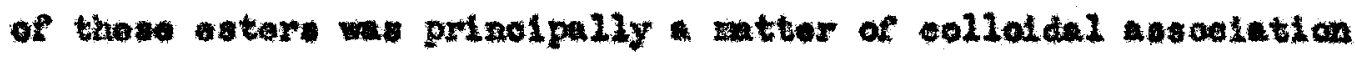

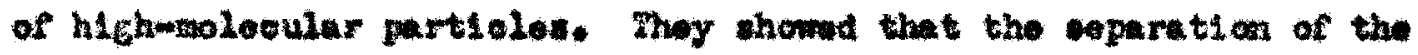

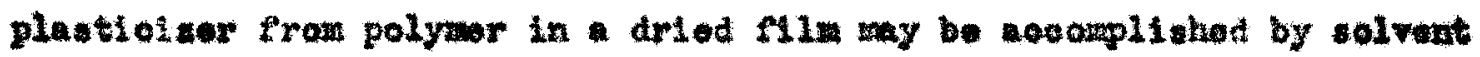

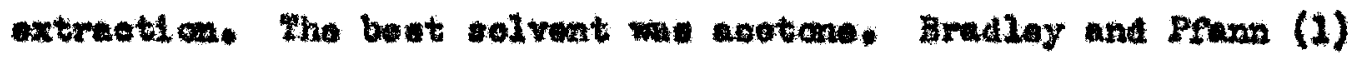


ctidice the hotmbodying of all and onoludad that both

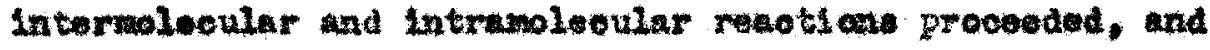

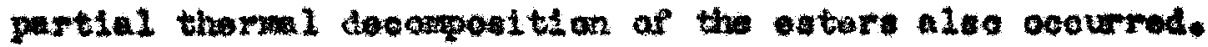
Thay aparated the ineolublo phave of an ol 1 gel frot 1 to

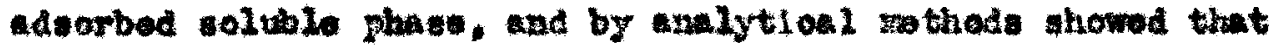

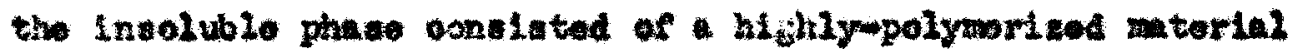
oongoulne 70 preent of the woight of tho gel. Wow and Ballog (28) alvided lineood oll plim into three corpencenta, Itquid, adeorbed 11quad, and selid. Thoy arm aerted thet the phyelowl nature of the film is depondont anserly upou the relative proportione in whis the cotapenonts oxiot in

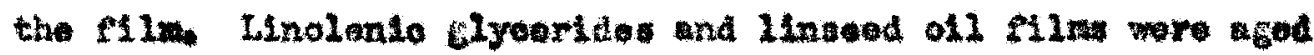

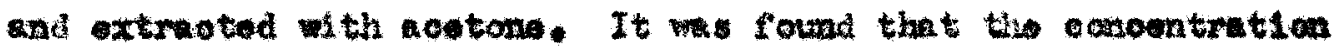

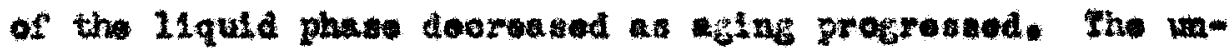

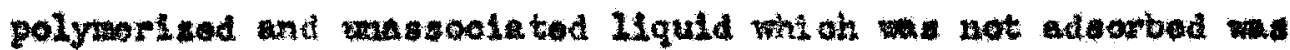
romored by extration, but tho cuorbed 1igitid probably mly partially romerva. 
T 


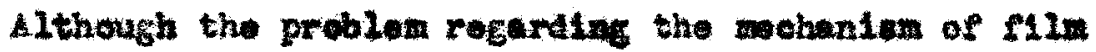
formation is of long stunding and he ropired oxtenstro troatwat in the 11torature, It ay bo umarkad by tatino that

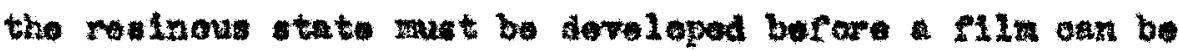

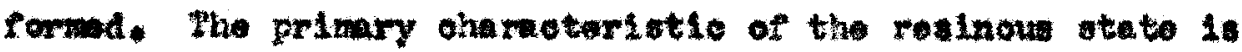

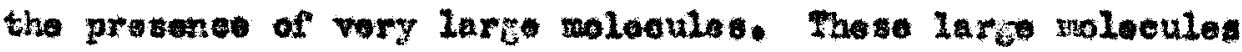

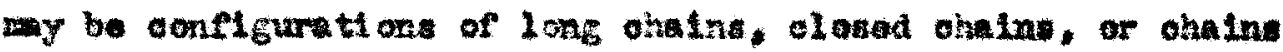
of arosu-1tated aha ractor.

The comogptent ragarding the reninous state have

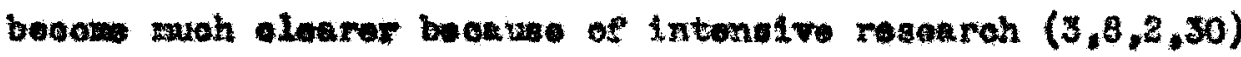
orried in in the siele of aymthatle resins during the past

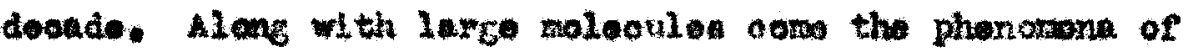
molocular complexity and larke molocular wareo aroa. Wo

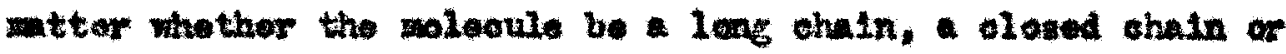
aroan-1inked etrueture, the opportunty for selemdattion of

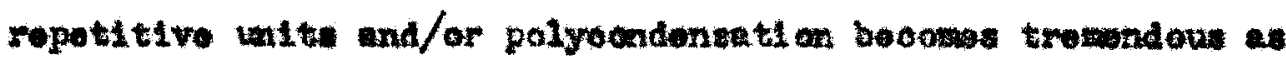

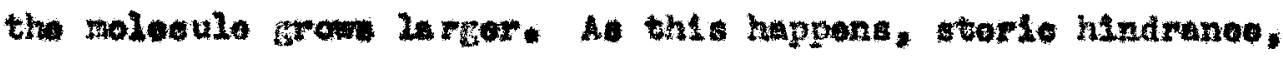

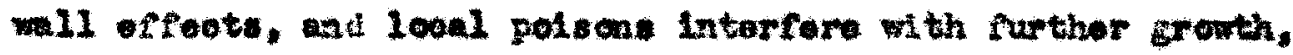

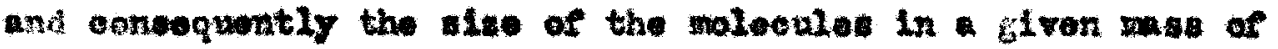
rouln varles owor wide rance.

The affoot of large waleoular surfwoe azo is to prosant an wasul opportunty for aloeula surrace foroes to com

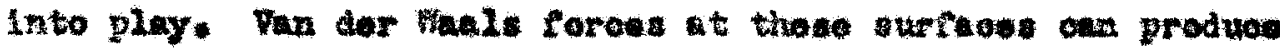

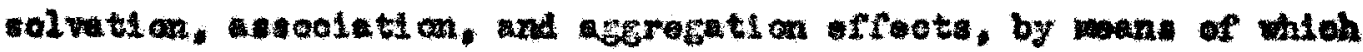


noleoulos my associate into moellar struetures or my adeorb forelga molecule: with erwat tonast ty.

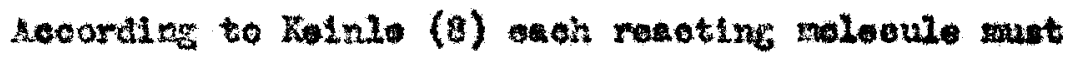

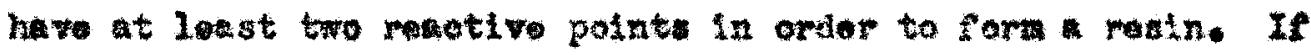

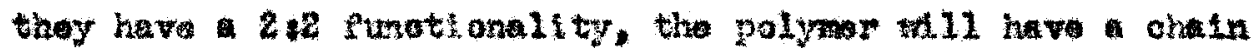

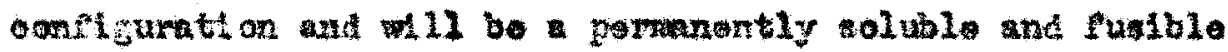

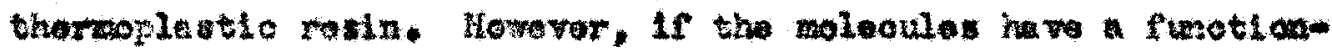
all ty erater then two, oroas-linking w11 oecur and non-tublblo.

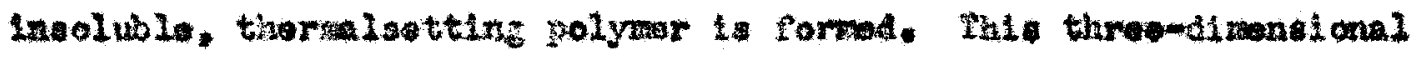
Intarlinkins roduoe to a large oxtant the high olestiolty that oheratarizo the ehain type atrueture.

The monat on of the "drying' reaction of dryine all 1. generally ocalidered to bo combination of axygen absorption and wolecular aseociation or polymorization. Although the formation

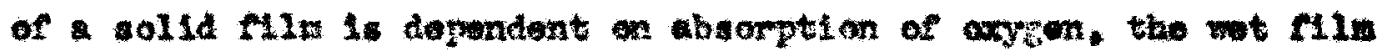
on expasure to air coss not imadiatoly take up axyen. The length

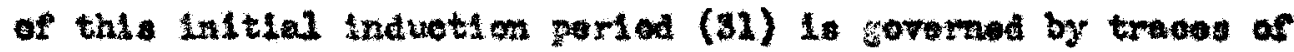
antioxidants in the of 1 and is aprootably thortonod by tha addition of molule trior: The oxycon abeorption is considered by noat

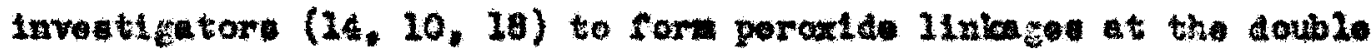

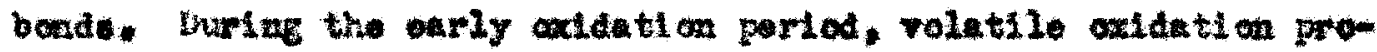
whet are split off, anone wht oh short-ohaln aldohydes, walds,

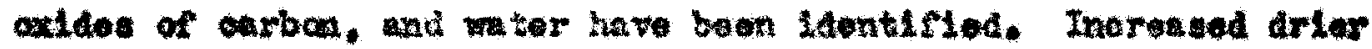

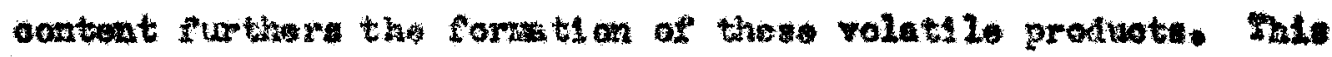


1nitial oxidation primarily oerveo to inoreases the poinrity of

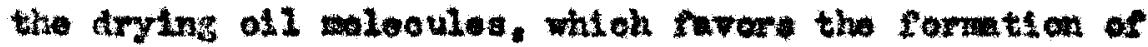
interlinkagen wi the other molecules.

Thwre are many controveralel data and opinions oca-

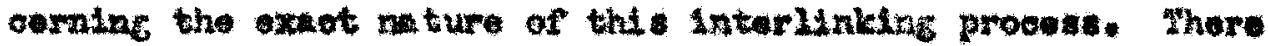
are two types of polymarization ronotions which might to plase. The first is the comblnation of unesturatod oorapound: by primary ohemical linkagex to forn larger molocules, tru

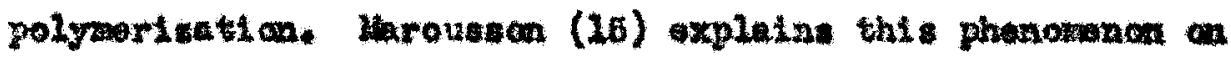
the batis thet tru polymoridos are formod notose oxyon bridges. It is also postulated (18) that the polymerisation take pleoe through the prtmary valanoe forcee of the peroxide groups, The second type of polymartsation poustblo is the

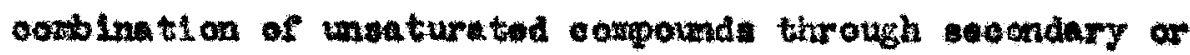

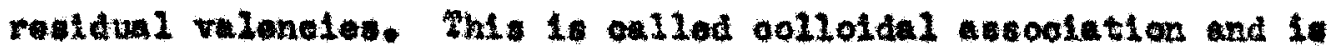
the recotion tomard with the latent experimontal work points (14, 16). The assootating or polymarizing rovotlon bring about geletion of tho ofl ond imoblie fils fortion. At this point no

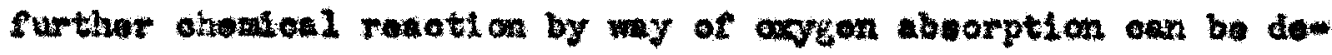
tooted. A gel ha boen formd, whioh consiats of a continuous

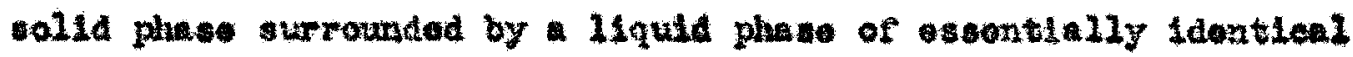

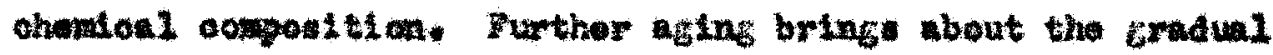
increase of the walld phase at the expente of the susarbed but 


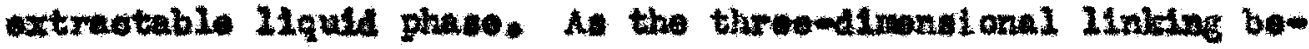

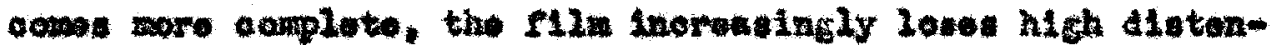

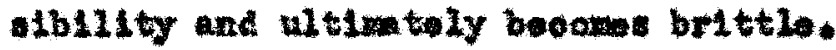

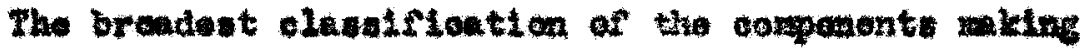

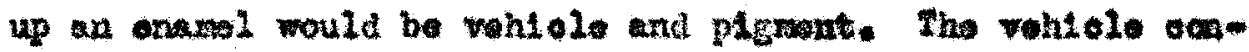
ctitutes the continuoue phate and the planont the dioparas or

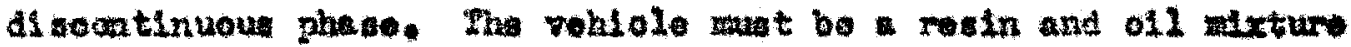

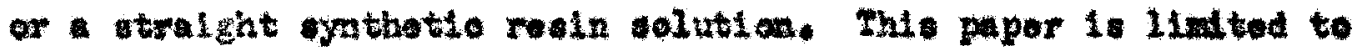
vohiolas in the fomer antegary.

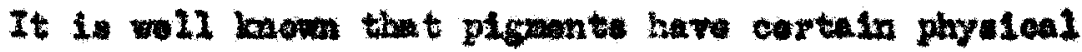

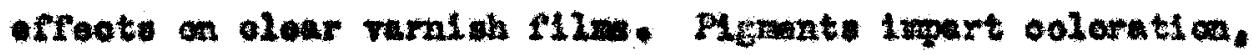
opaquenes:, wad the allity to exeltude altra-violet light. The

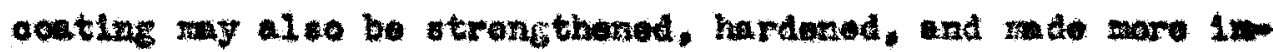

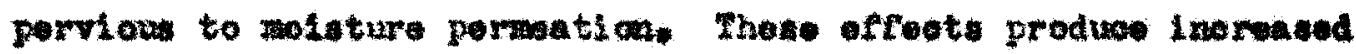
durab112y.

A prim requalto of all pignente is that the sies of the irutridul partiole be smil. This is nesesent in ordor to

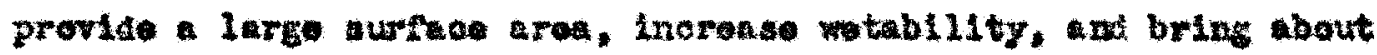

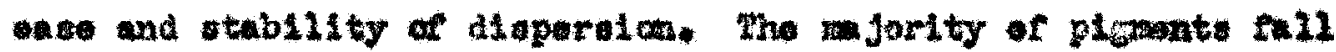

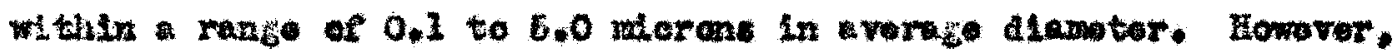

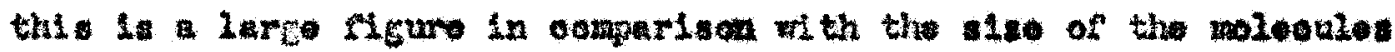

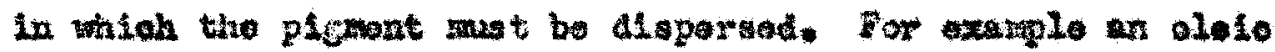

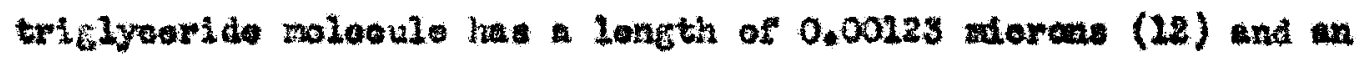




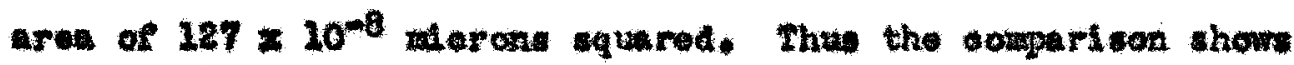

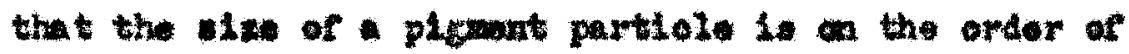

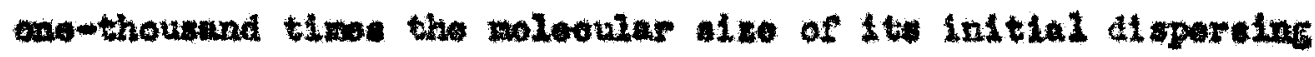

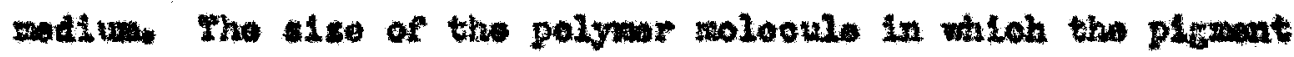

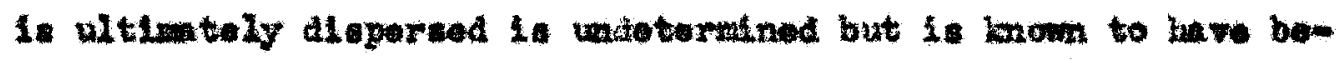
gat trowandous.

Stno the aise of the plemat partiale is oomeratelvely Iarige 1t followe that the partioles wil be aoouroly bound in the

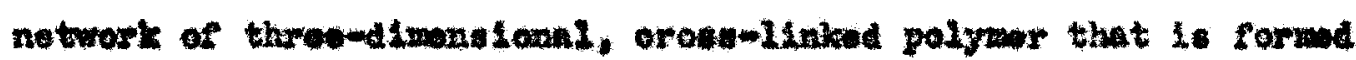

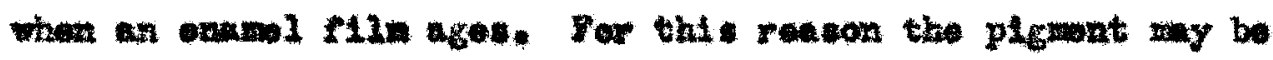

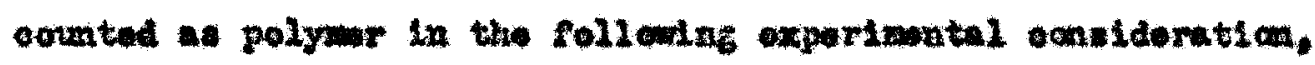
Ines thare oxicte 11ttle chane of ito bolns "mohod" out of the

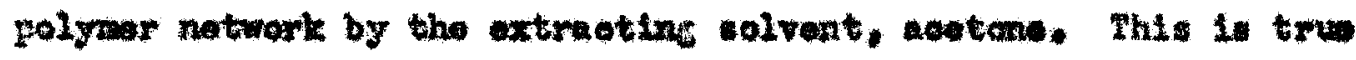

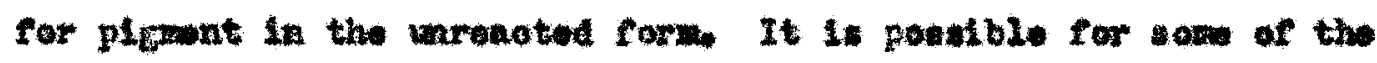

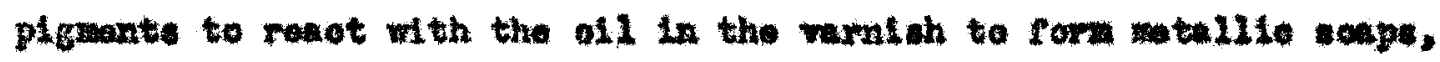

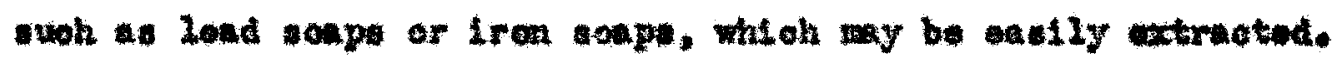
The plgmente ray have othor exfects on the rilu besldes adalne the buli of insoluble tertal. Tho plgmonts under conclderation In this lavestigation aro lnorgunte alt and acides of

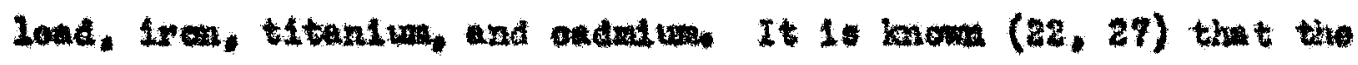

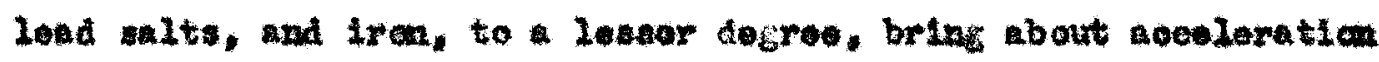
af the antation of a film and lmoreate the total apount of axyen

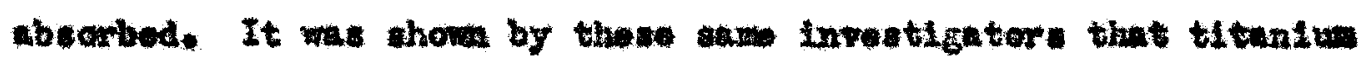


Aloxide had axnotly tire oppost to of oot, retarding tho axidation

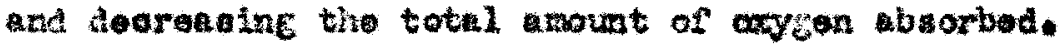
SAnce oll polywerization of oloorosinous films is a funets on of oxtdation the polymer entiont or poroent unoxtractublo

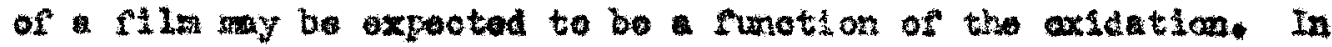
other words, the rinal ralus of the polymer emtent of the polynar ontent at fallure should be finction of the total erount of

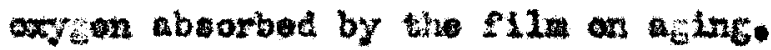

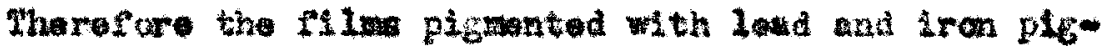
ments should shor value of polyner ocotent at fallurs, highor than

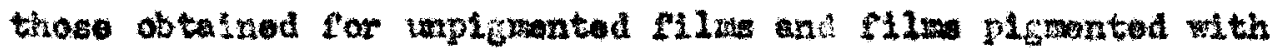

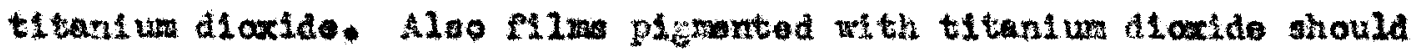

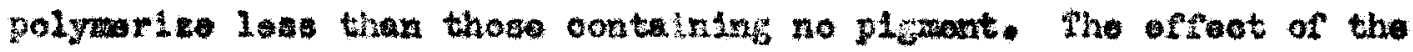

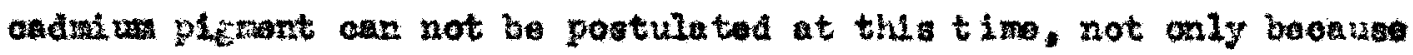

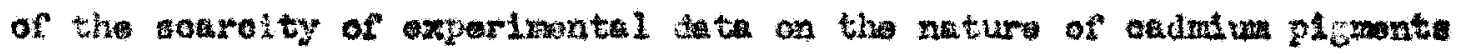
(ro, film atruoturo), but lso bect the partioular cadailu plewent used in this fnvostigation in ono thet tonds to ploculete lnotad of disperse in oretnary rohzolese

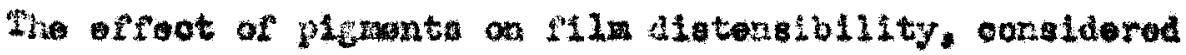
from film aterueture angle, tond to conpllonte the tructure of

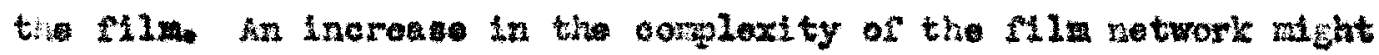

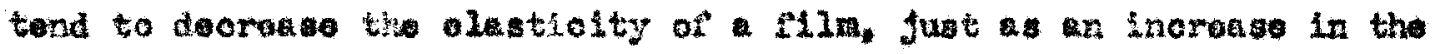
amount of three-dimonatonal, orose-linked polyrour doow. 
If the problom is eppronchad from grationl potat of viow the anower appoara to be diffarat. It is zenorally

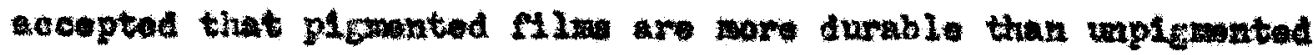

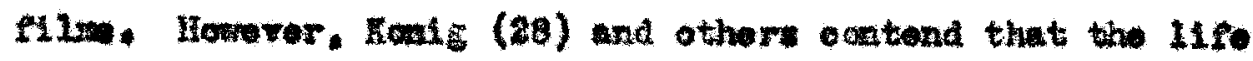

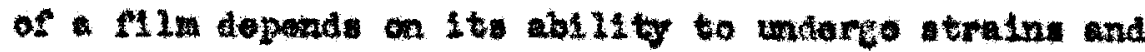

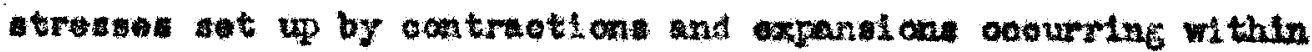

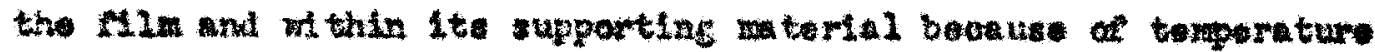

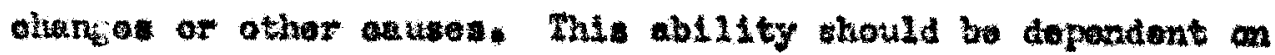
the alotensbility of the flin. Thu the more dumble onami Al hould have stoter ditenatbilsty. 


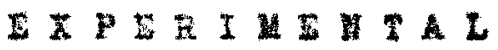


RAI HATILLS.

The raw aterials woleoted for this invesigation troludad atweral typioel inorgente plgants chosen beoause of their variation in chomical and phystoal nature, somo typlonl varnishes tulan from the previou inventication (4), aryinc olis to blend of th the plemont-varalsh miturea in order to obtain tho corroct oll loneth, and thinners suttable for thinning the formulations to the desired conststency.

The plgrants used were pure titanium dexide, having a wpoeiflo gravity of $\$ .98$, bulkine ralue of .03118 , and an oil absorption of 24,2 , buale carbonato of whto load, having

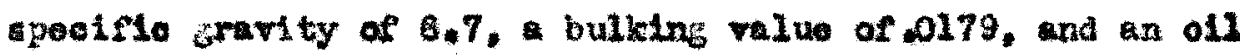

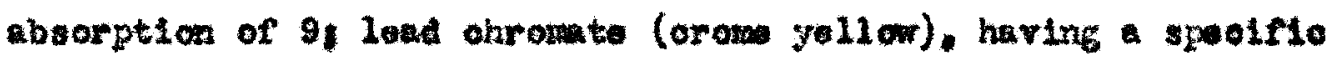
gravity of 6.01 . a bulking value of .01998 , and an ofl aborptlon

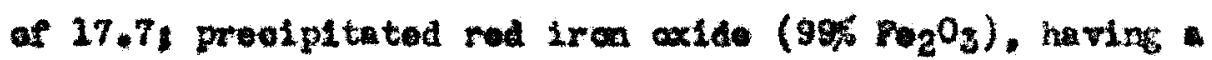
specirse grarty of 5,15. bulking vive of .0240, and an ofl

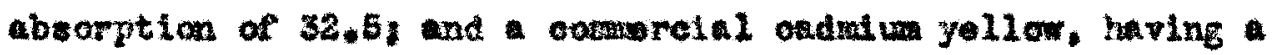

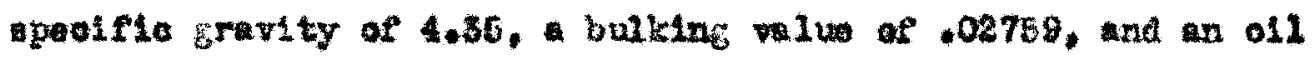
absorption of 2.5.

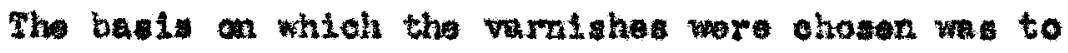

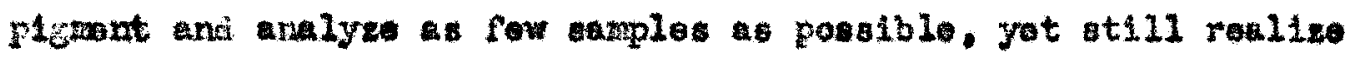

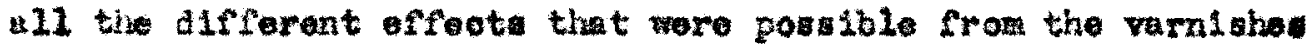

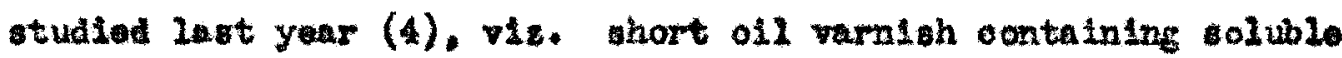


rasin, short ofl varnish oontaintig insoluble resin, lons oil varnieh containite solublo rosin, short oll varniah oontalnine Insoluble rosin. plus variation of drying oll. The varnishes used in tha investigation fnoluded 16 gallon lineod o12-

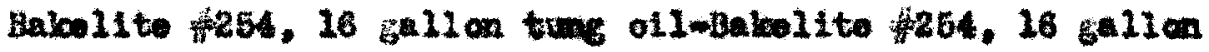

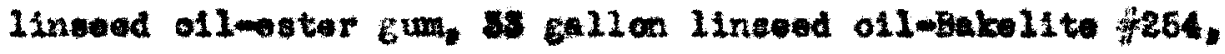
33 gallon Iinseed ofl-ostor gum, and 16 gallon dehydratod oator oil-Bakcelit to 254 .

The dryine olls used are those inhorent in the varniches

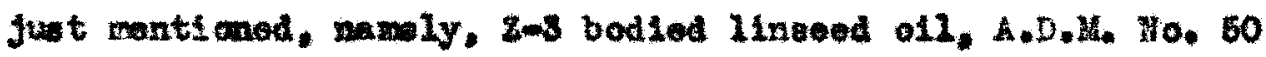
onlorisod oklnawood oll, and dehydrated oastor oll (Symthonol). The thinners used were meral splrits, havine apecifto gravity of 0.792 and a bolling range of $153-204^{\circ} \mathrm{C}$. , and xylane, having * specteto gravity of 0.865 and bolling range of $136-144^{\circ} \mathrm{C}$. silnoral oplrits was used to thin the onemol oontainine ester sum,

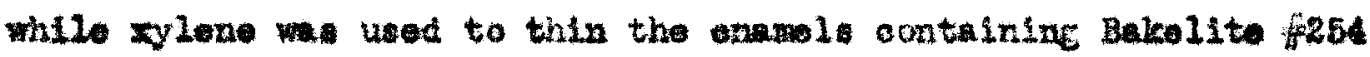
resin.

Drior was alvo added to the formalatione in the form of rocular tuodex load, mancanose, and cobalt driers, oonteining 24, 6, and 6 peroont tal, reapeotively. They wore added to the enamol formulation on atal to ollmdded wolght basis of 0.30 peroent load, 0.05 peroant mangese, and 0.015 peroent cobelt. The monanism of enavel formulation of peotively to roplsoe cne-half, three-tontha, and seven-tentha of the varnish 
resin volum th plgment volum. That la to say frow ow

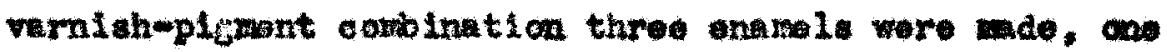
having plemont-resin volum ratio of $5 / 6$, one having the ratio of $8 / 7$, and one havine the ratio of $1 / 9$. For the purpose of clariflatian tho formulation of one of the onamela bo oonsidered TLBI-5. This code formula rofora to a 16 gallon,

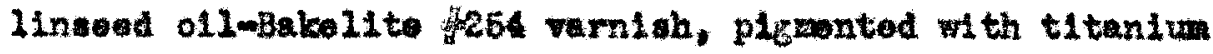
dioxide so tint the pignent-resin volum ratio of the ultimato oname 1 is $5 / 5$.

The andyol of the varnien is

$$
\begin{aligned}
& \text { Lingeod } 011-28.55 \% \text { (mt.) } \\
& \text { Bake11to }-22.26 \% \text { (wgt.) } \\
& x_{y} 101-49.20 \% \text { (rot) }
\end{aligned}
$$

The eorpostion lesirod in the fint shed onatol on a volue basts $1 \mathrm{~s}$

$$
\begin{aligned}
& \text { Linseod of - } 16 \text { rolumes } \\
& \text { bistell to - } 5 \text { voluas } \\
& \mathrm{THO}_{2}-6 \text { volumes }
\end{aligned}
$$

Tha oosposition is transterred to a reight besis by wultiplying the volu of sach constituent by 1 te poolflo jravity

$$
\begin{aligned}
& \text { Linsead ol - } 16(.99)=15.34 \text { woight unfe } \\
& \text { Bakelite }-5(2.2)=6.00 \text { weight units } \\
& 110_{2}-s(3.9)=19.60 \text { ight units }
\end{aligned}
$$

Since it is obviously ixpoasible to take rosin out of tho varniah. It is nocessary to add oll and plgwont to the varnish to get the docired combintion. All tho rosin in the finiehed enane 1 mast come from the vamiahs therofore quantity of

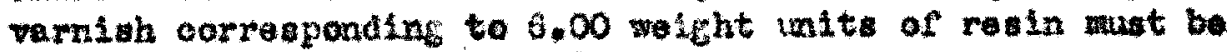
teleat a atarting tarial

$$
\text { a woint of varnish }=6.00 / .2225=20.96 \text { weint wate }
$$


But this arout of vamiah will also furnish a quatity of oll quantity of ol1 $=26.95(.2055)=7.68$ molight units

The amount of all dotired is 15.84 waigt wite therofore sans oll zast be added to wateo up this differonce

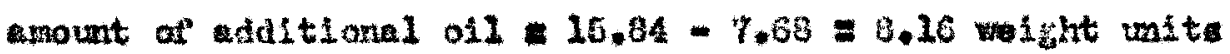
The wount of plemt added is tho sene at provlously oaloulated. Tharefore the atul coryosition of the formatation is

16 gellan Inseed-Batolite varnish -26.95 weicht units 11nseod oll

$1 \mathrm{O}_{2}$

- 7.86 wicht units

-19.50 weicht units

This if the way the formulations were onoulated wh the

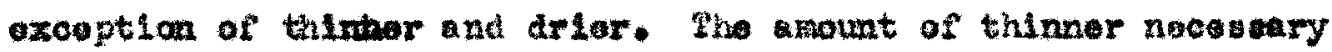
18 calculated in a dimlar mar and 2 oqual to a quantity nocesenry to sive the flual onamol the samo volum paroent of golld thet the orifinal varmish ha. The dotermination of the Arler adied 16 mado by a siple weight ratio.

The formulatione considered in this investigation are thom in Table I. Let st be exphasizod that ach horizontal

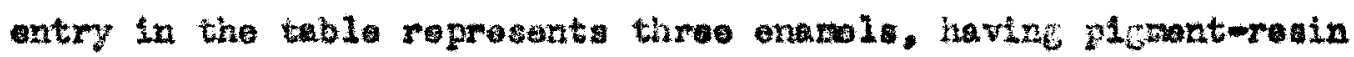
volua ratios of $5 / 6,3 / 7$, and $1 / 9$ rospotivoly.

The formulations libted in reble $I$ were not chosen in hapherd remer. Instand, they wore selocted with the iden of

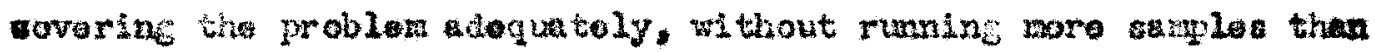
oould be handled. The formulaton bring about the following

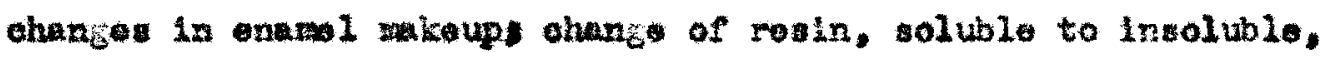
ahange of pigant, reative to now ractive, change of oll-1sacth, and ohenge of dryine oll. 
TABL 1

pondursons

\begin{tabular}{|c|c|c|c|c|c|}
\hline code Mo." & O11 & of 1 Langth & Reetn & Plgaont & Thlmor \\
\hline $\operatorname{TLB} 1-5,3,1$ & Lincoed & 16 & Selvellto & Pltant un dicalde & xylem \\
\hline DLD1-5,3,1 & Intead & 16 & Bakellte & Bcht. & $x y \operatorname{lon}:$ \\
\hline $1201-5,3,1$ & Linead & 16 & Babelite & Lend okremet & $x y 2=0$ \\
\hline $2,153-6,3,1$ & Hnseed & 26 & Dakolsto & Iron rod & $\mathbf{4 y 2 0 2 0}$ \\
\hline $21-1-0,3,1$ & tans & 16 & Selandito & 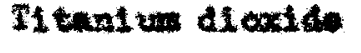 & Xylen \\
\hline $5782-5,5,1$ & Tace & 26 & Eakelste & actix. & Iy 20 in \\
\hline $\operatorname{TIB1}-6,3,1$ & Tras & 16 & delese ilte & Lod chrow to & Xylan: \\
\hline $281-6,6.2$ & Irag & 16 & Babolite & Iras rod & $\mathbf{x} \mathbf{r}^{\mathbf{l}}$ \\
\hline $21 x 2-5,3,1$ & Lnowa & 16 & Eistar ste & Pitanim dioxide & Mnoral \\
\hline $01,1-6,3,1$ & Lesteowa & 26 & seter gux & BCEL & Hinoral \\
\hline$T L Z 1-5,8,1$ & Linean & 16 & Eater cum & Load chrombe & Mnera 1 \\
\hline $\operatorname{cts} 2-6,3,2$ & Lnbeod & 26 & Eater gom & Iron rod & Anorin \\
\hline $7438-5,8.1$ & Linwead & $\mathbf{5 3}$ & Bulelite & ILtaniva alocito & Xyllowe \\
\hline
\end{tabular}




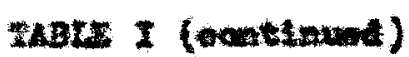

Potumatros

\begin{tabular}{|c|c|c|c|c|c|}
\hline code vo." & al & al hangth & vecta & Ptent & Phimaser \\
\hline 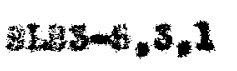 & Laneved & 3 & Bukellto: & wot. & xotome \\
\hline Fte & Intaved & 89 & antore gur & 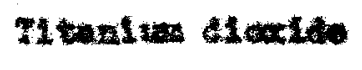 & atomel spto \\
\hline $2 x=5,6,8,1$ & Lnowat & 36 & Etex gut & act & 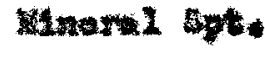 \\
\hline $231-5.9 .2$ & Sueter & 16 & geterite & 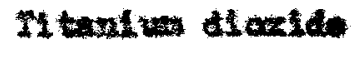 & Xylow: \\
\hline and $-5,5,1$ & Cusser & 16 & Halkeliste & $\operatorname{sent}$ & Xylen: \\
\hline $0.51-6,8,2$ & Whased & 16 & gatedite & Cadiu vellem & Xylaw \\
\hline
\end{tabular}

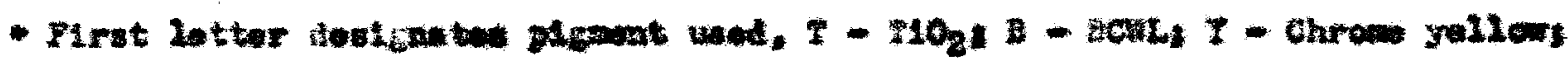

f - Iren rots and c - cd culpuldo

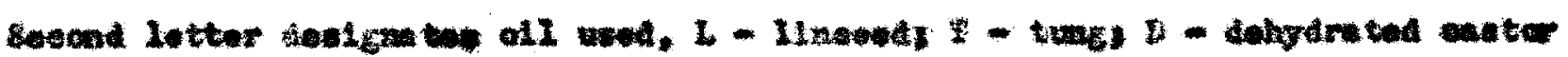

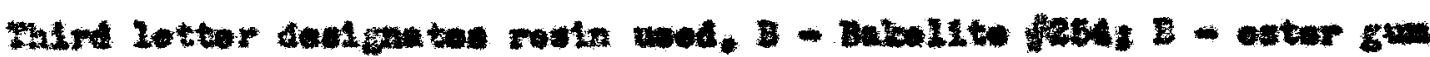

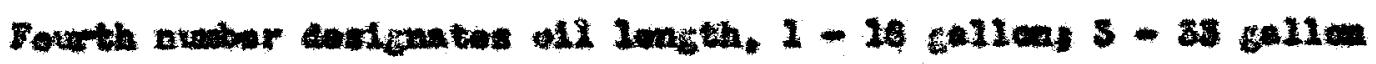

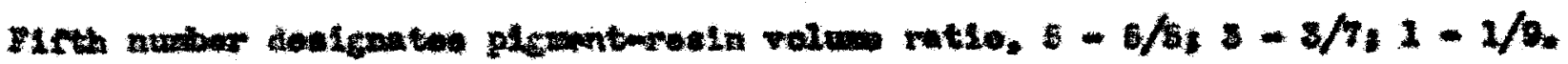


AFfondus.

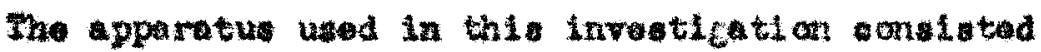

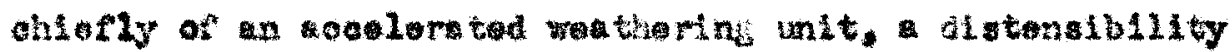

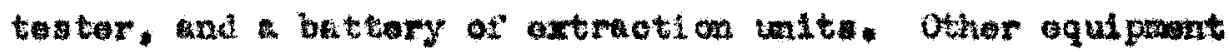

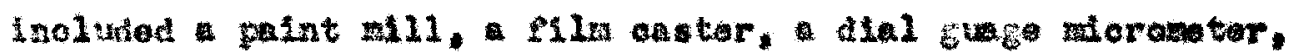
and o onotant-texporature, oosstant-humdity obinot. A11 this

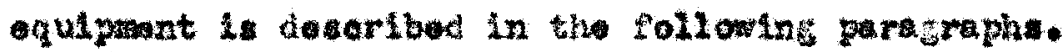

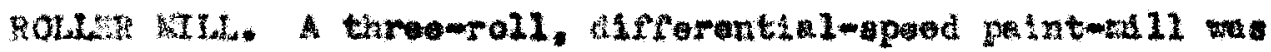

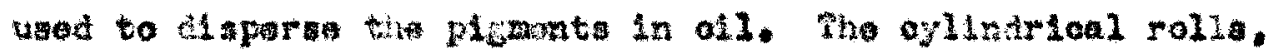
6 incher lone and 2 inchos in dianoter.

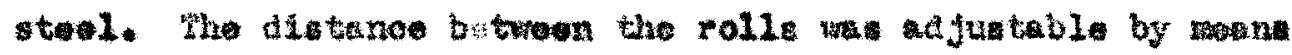
of hant sorerat.

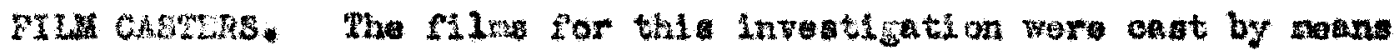
of a dootor blede baving clamance of 0.000 inches. sho oater

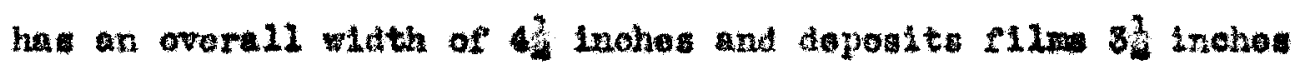

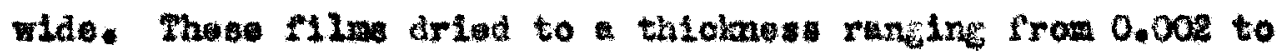
0.003 inchos, depending on the solld contont and viscolity of the

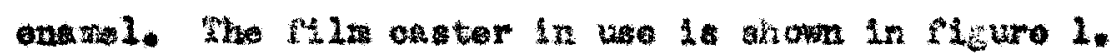

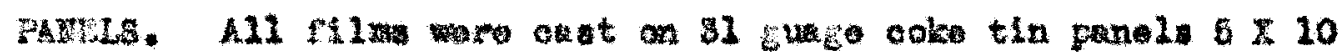

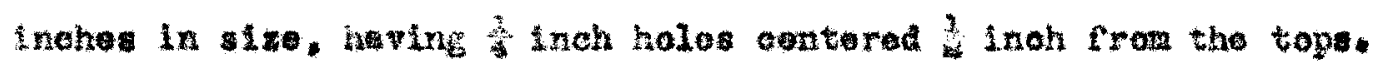

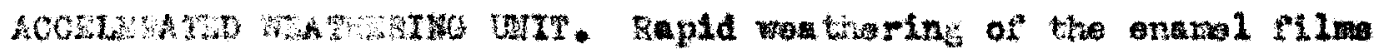

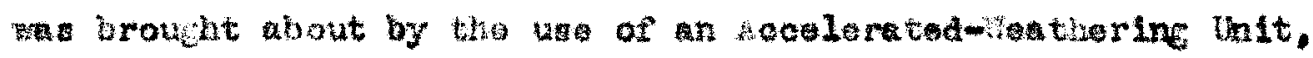

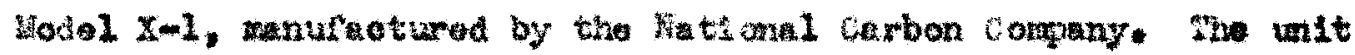

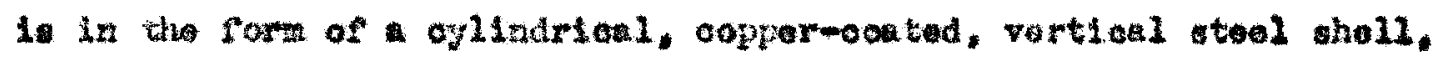




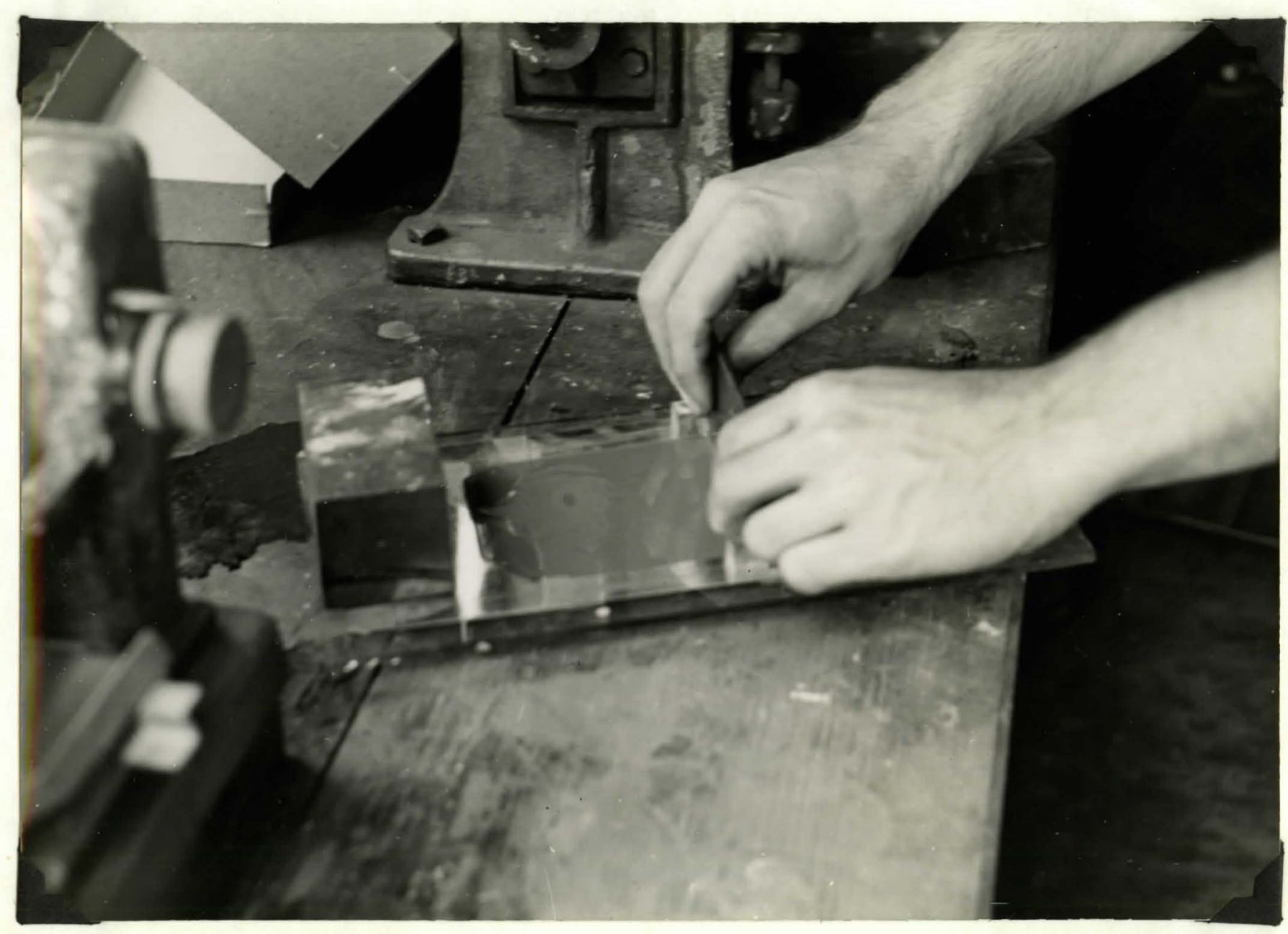

MIg. 1. Casting enamal film on tin panel with doctor blede. 


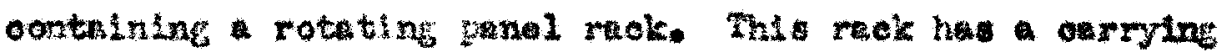
eapacity of staty-four $3 x+10$ inoh panels, and rotatos 360

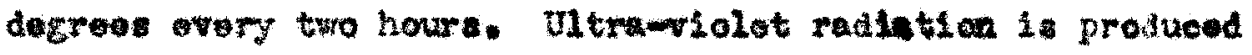

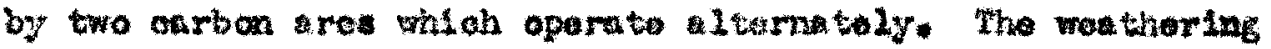

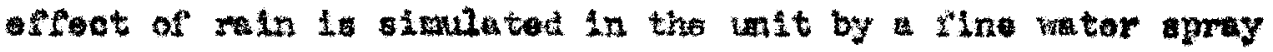

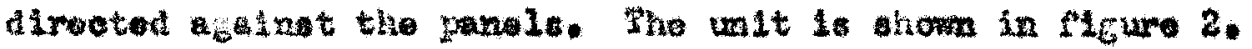
Wow

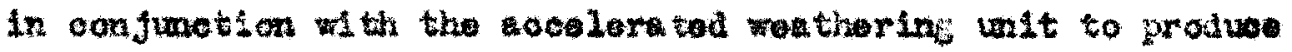

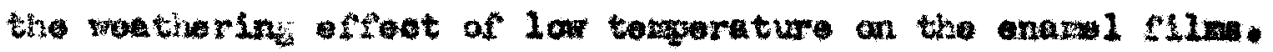

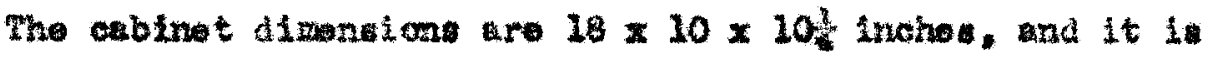
oocled by the oxpanston of ansonita in oolls.

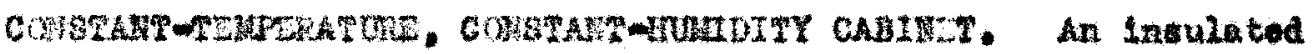

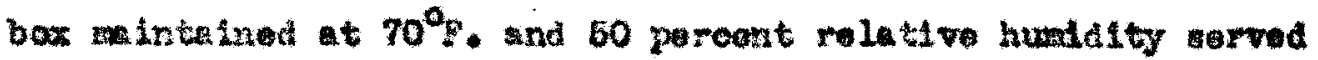
a constent-tangorature, ongtant-hualdity obinot. The tomaraturo was intainad by tharmostatically operated incundesoont

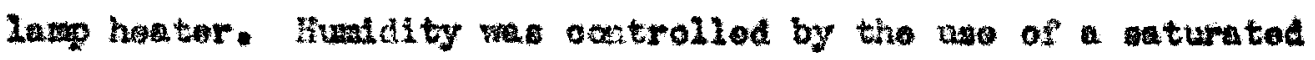

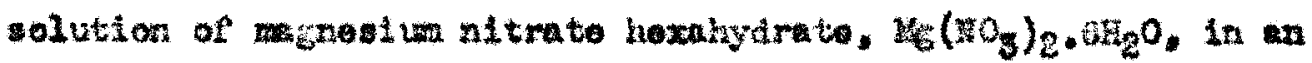
open pan a sucsetol by ardar (7). Such a olutson, whon oon-

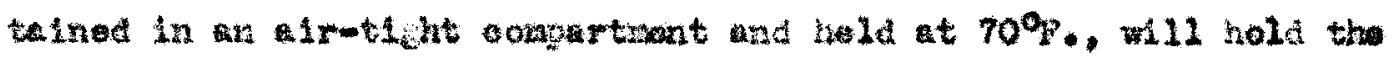

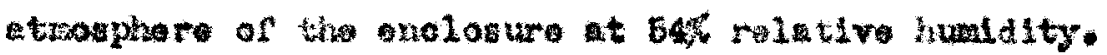

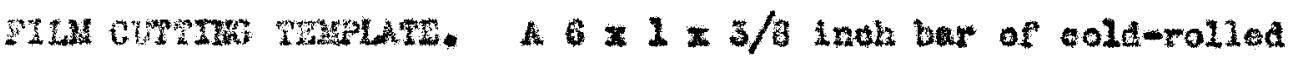

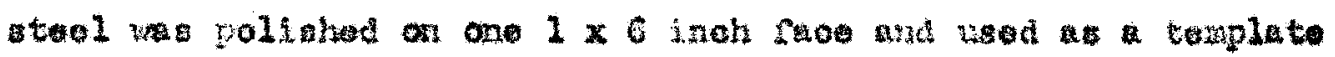

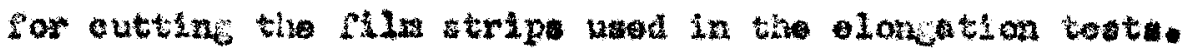




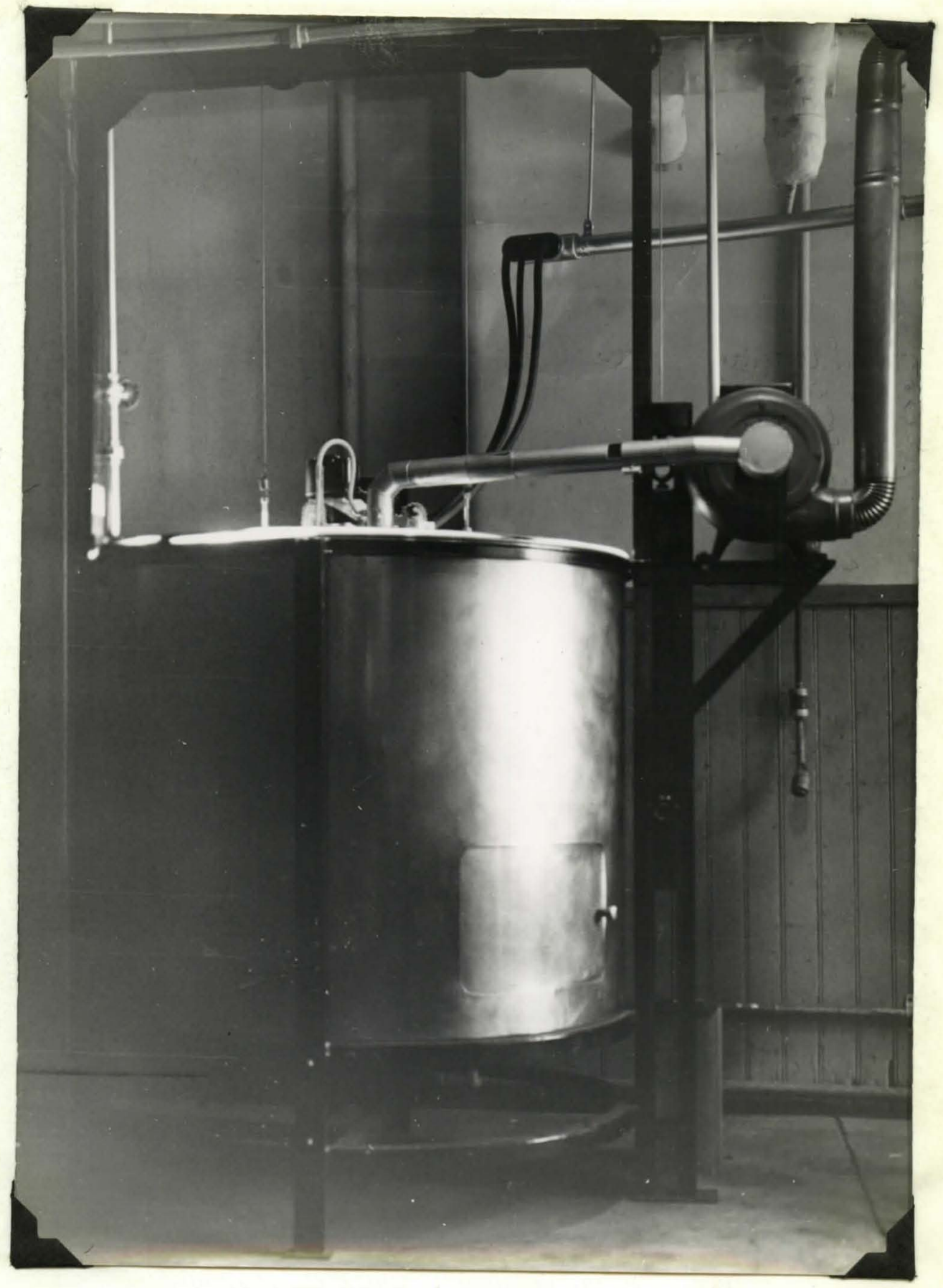

Fig. 2. Aecelerated weethering wit. 


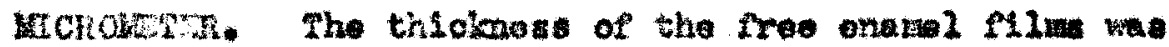

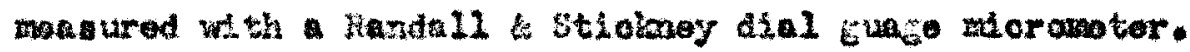
Tho microwoter is craduated in thousandths of an inoh and reading can be interpolated to ton-thoughndthe of an inch. Seo figure 3.

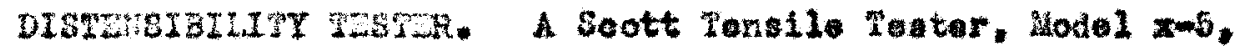
was used to determine the perount elongtion and the tensilo

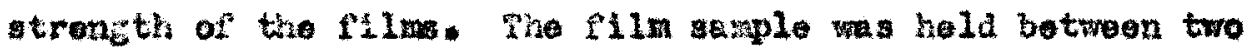

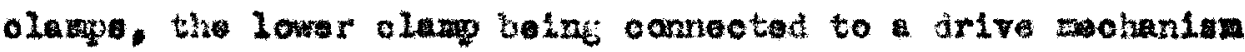
which produced conotant opood pull of tro knchos per alnute.

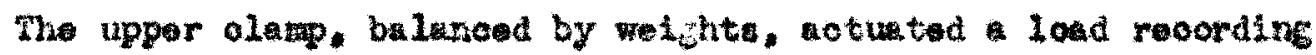
pointer and dal. Tho toster has a doublo operatine oapalty of 0 to 2 pounds and 0 to 10 pounds. 500 figure 4.

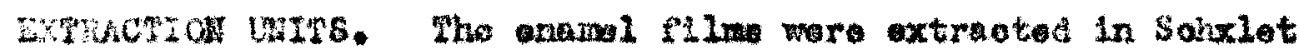

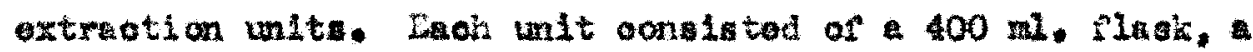
sphon oup. on extraction thimle, and condeneor cap. Tho

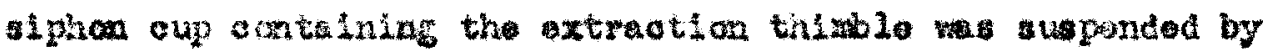
fate whe fros the condenser ap which retad on the nock of the

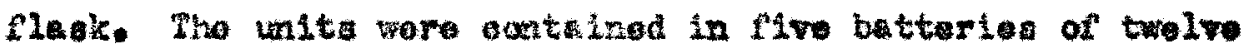

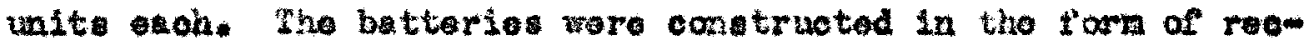

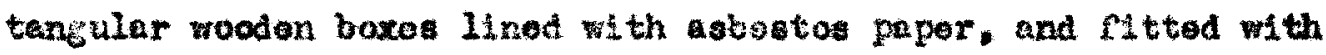
retavable lids in whin halos were out to recalve the oxtration

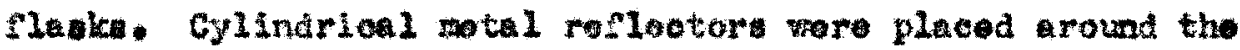
Pleaks to diroot the het from the 75 wht inoandosent lanp 


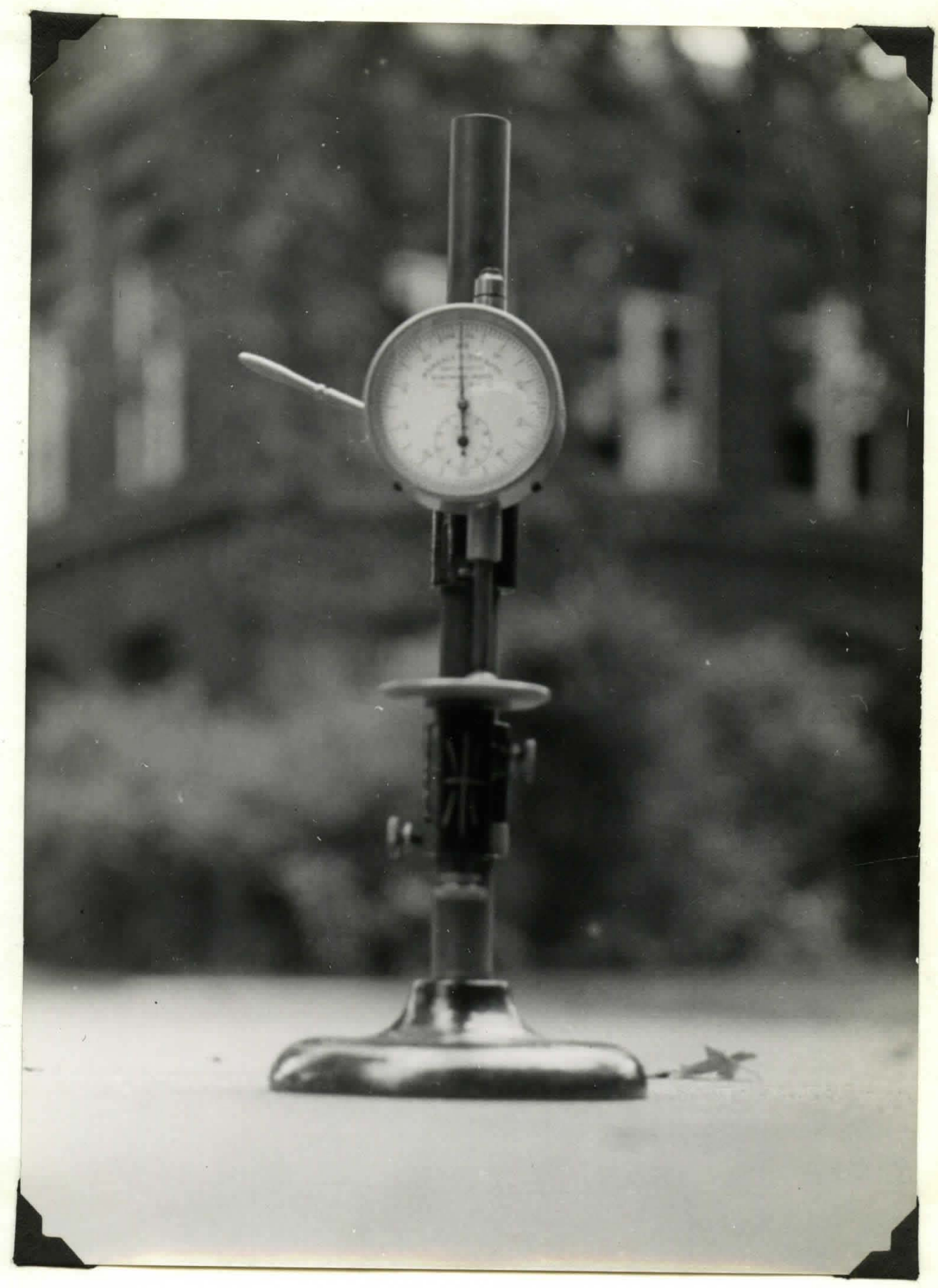

Fis. 3. Meromoter. 


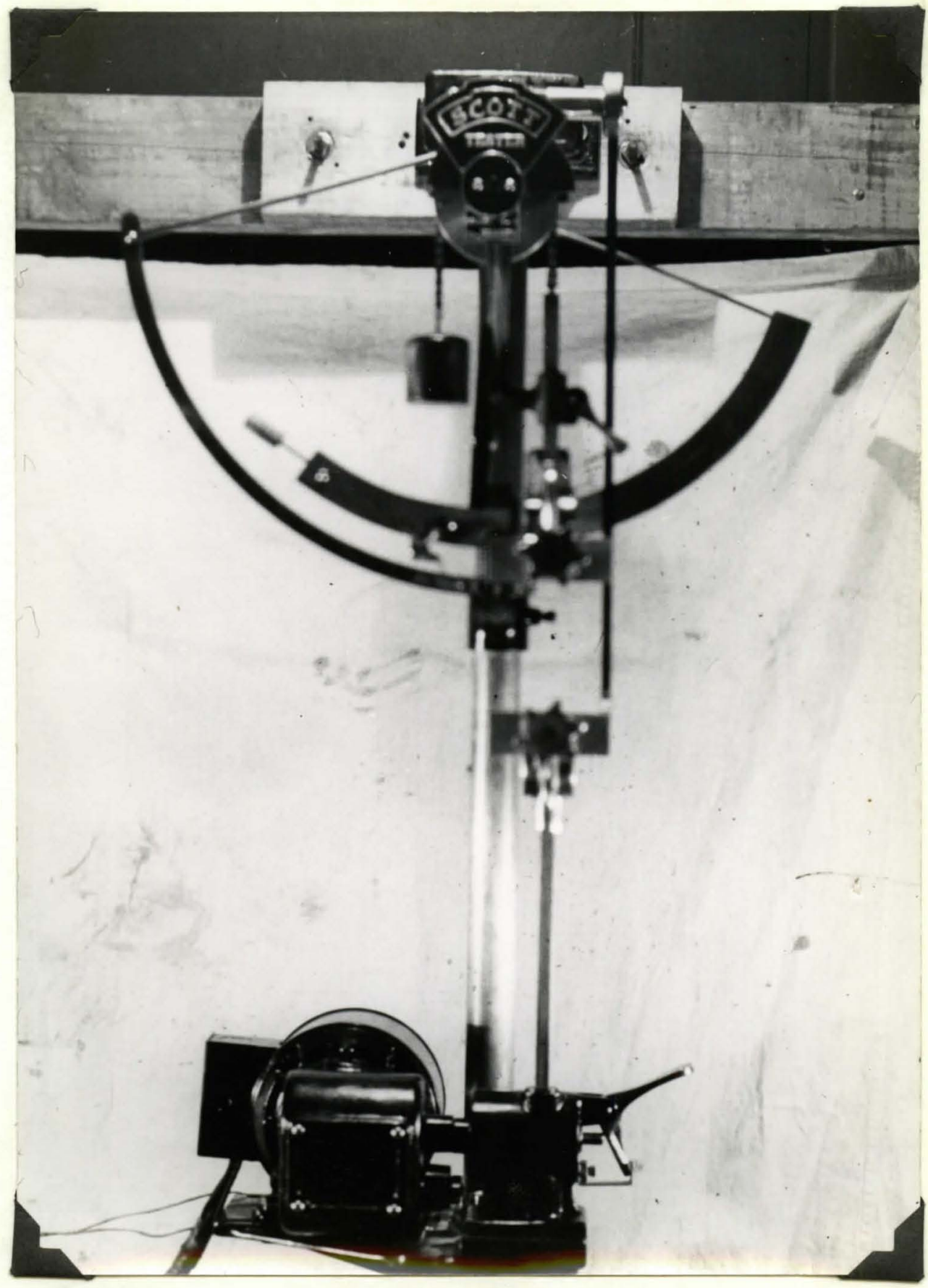

Fis. A. Diatensibility tester. 
hotors. Coollne tor for tho condenaer we auphled

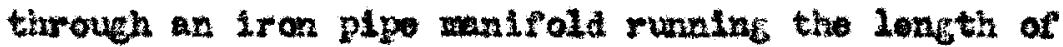
the unt. See felgure 5. 


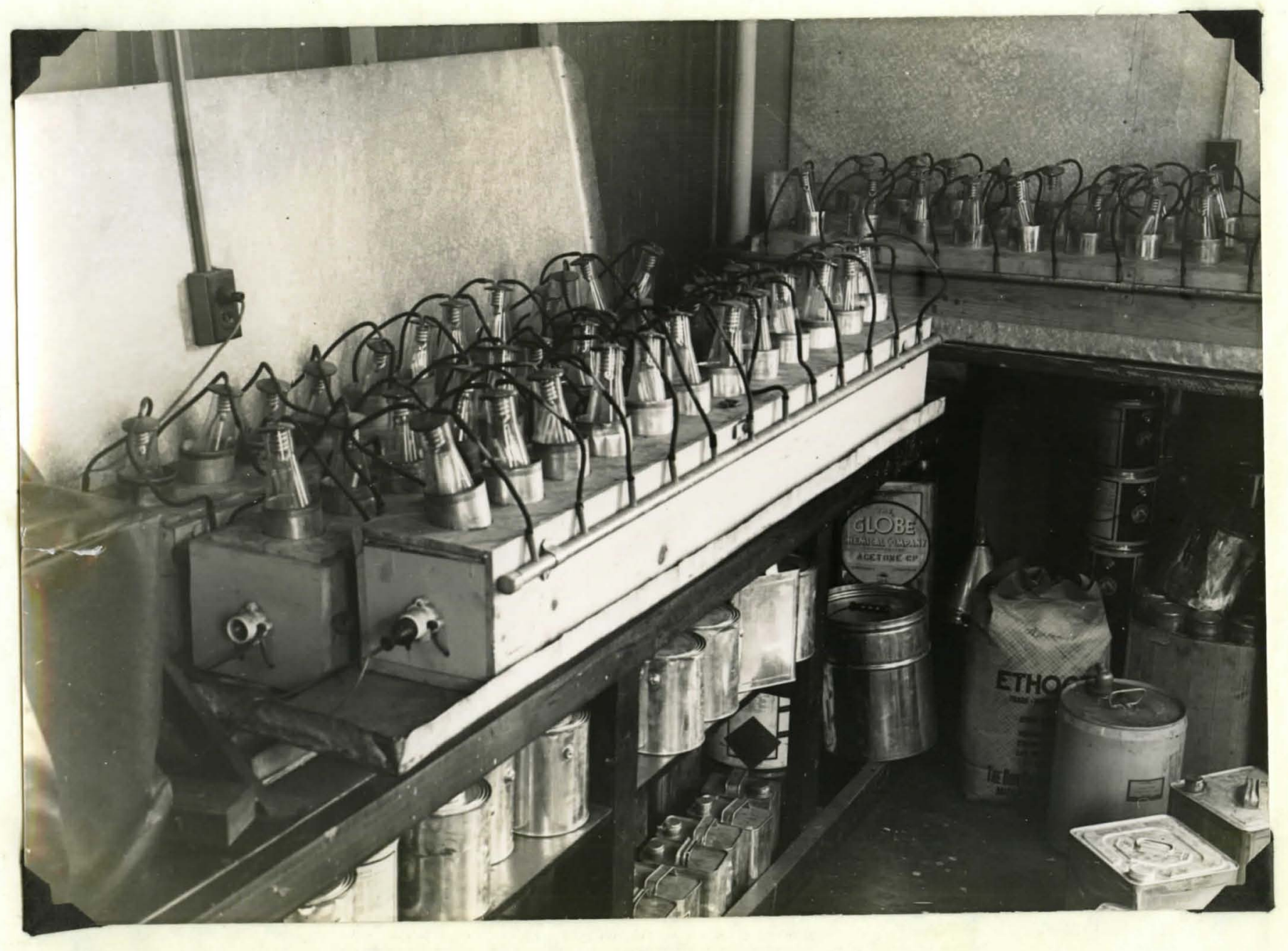

PIE. 5. Extraction buttorles. 
ProcLDUE.

The general proveduro oundated proparting the onamis, casting the filme on penols, and ofinc theme The panels wore thon axalemed and the silme stripped froo. The sroe flin were thon condtionod, elongated, and oxtractod: Ech atop is explatred bolow.

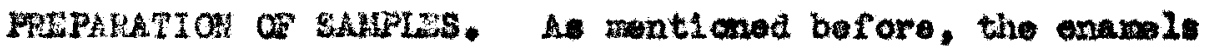
wore formulated from varnish, plgwent, oll (the san frow which tho varaish propared). thimner, and artor. Tho oorrect portions of oll and plement were malxod to form a pate. This paste who than posed through tho throomroll 2111 to wet ard as aporse the plement particles thorougly.

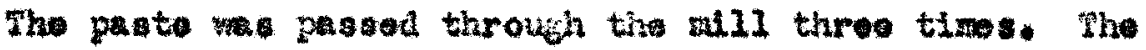
varnibi, thinner, and driors were then added and the atxture agitated tharougly to obtaln homogeneous aixture.

Castino a pIIts. Plate dase panole were lovelod, and few drops of weter were sprosd on the top surface. Th papels, thoroukhly cleaned on the top auffao with xylane we firmly prosud osto tho watted slasa platas to make the two adhere. Thlo presented a Mat, atationery atal gurface. The rilwo wore thon cant wh tho doctor blado. and a constant, forwerd pull of I-2 tnohor por soond wa axereised by the operator. All thas were cast in duplloate. 


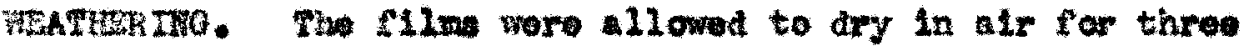
days aftor cacting or untll they wore no longor tadky. Tho manole tre thon trimed to $a^{x} \times 10$ inohos and plocod in the oodoreted wathering unit. Here thay wor exposed to the cotion of ultre-rolet 11ght, water epray, and refrleremt10a for pertode of 2, 4,6,8, or 10 oyeles. The 24 hour cycle used based on that doveloped by the comomenth

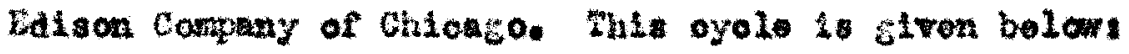

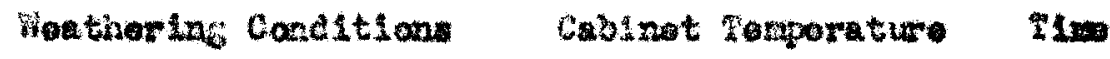

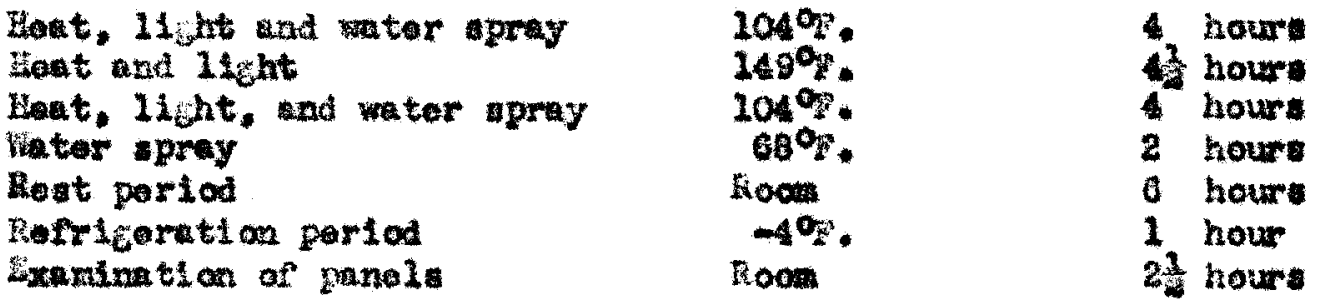

Ae inferred in the tablo above, the ganels woro onrofuliy inapoctod the and of ouch oyelo for chalking, los on zlost.

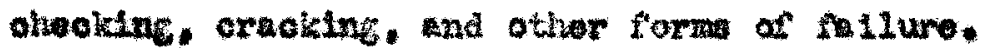

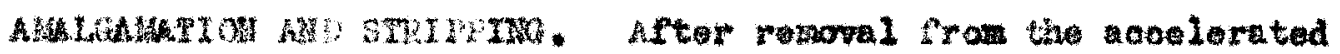

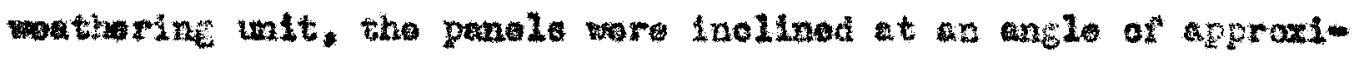

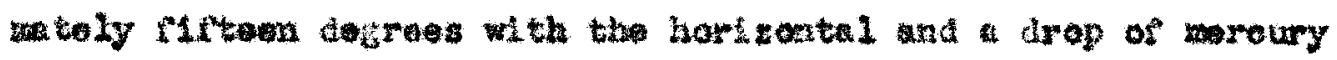
was plaoed an the unprotected rotal ourtace above the top odjo of

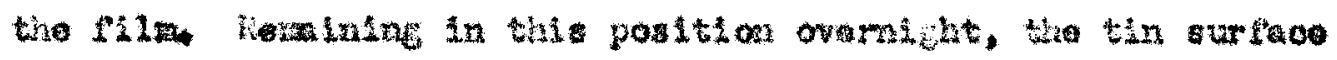

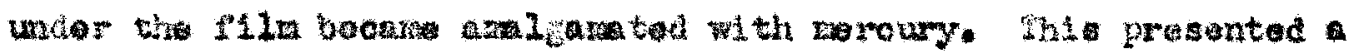


surfaco to which the Mlim ald not ediere. On the following dey the edices of the filw we trimed the rasor blade and the

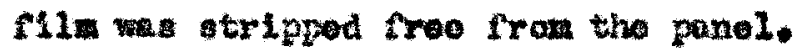

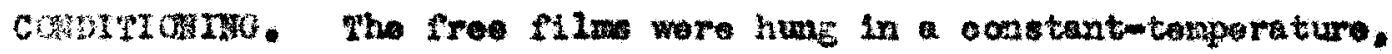
conatant-hundity cabinet for throo days of moro. Thi oatud

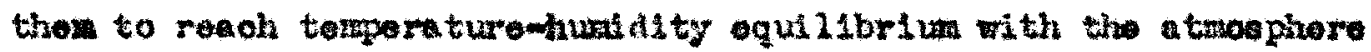
Instde the cublnet.

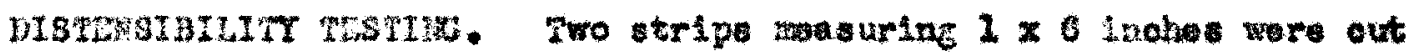

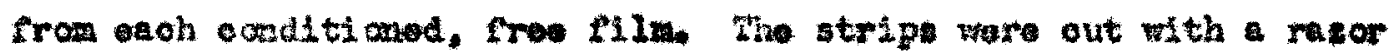
blade, usine stoel tomplate a patom. The thicknese of these atripe were then determined by averaging sevarel reading taken with

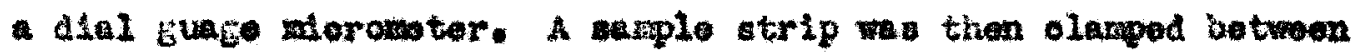
the jaws of the soott testine wachine and tho load appliod. Tho elongation of the $12 \mathrm{l}$ and tho load requitrod to broat it wore re-

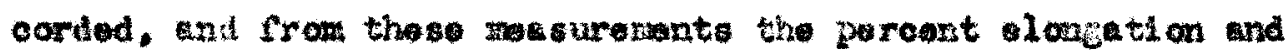
the toristio otroagth of the film were detorutined.

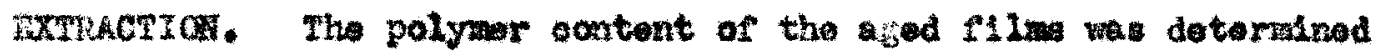

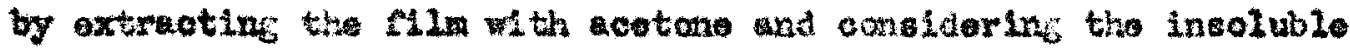

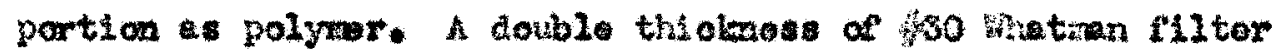
paper wes solded into a doulo taloknese, Mhatun-uxtraotion thifiole. The thislo then extrueted wh theotono for two

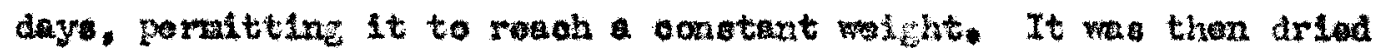
et $10 \mathrm{~g}^{\circ} \mathrm{C}$. Lor two hours, cooled in a desateator, and wothed. The

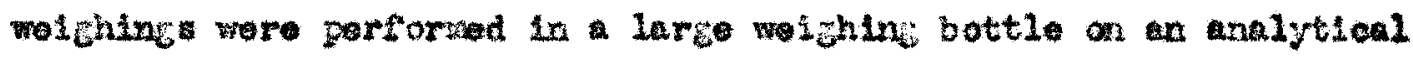




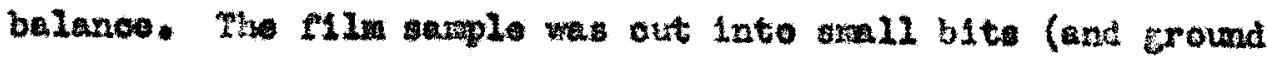

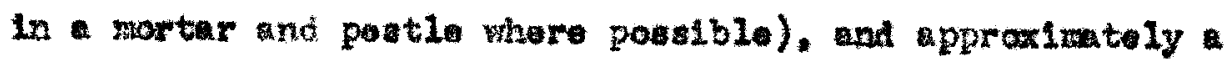
Graw and half was placed in tho thimblo. mo thinto wa

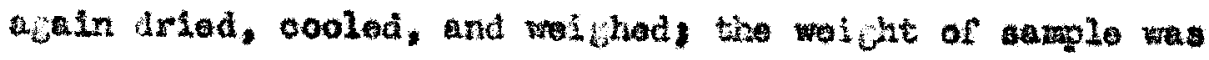

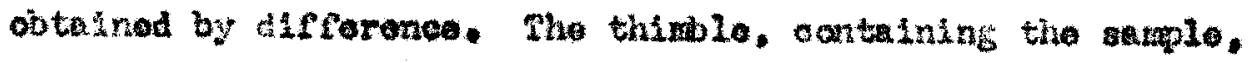
was thon placod an an oxtraotion ant and axtratod for apm

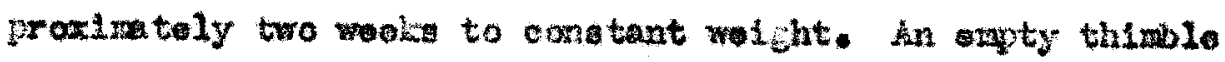
wa axtractod with ach ten saplos a blank, to nlnimise errora raculting from slight changes in the welut of the

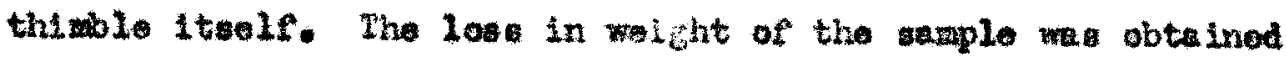
by differenoe, and tho peroent of insoluble torinl ramingn saloulatod. 
Rovitrs.

Tho formulations. previoualy ghown in fable I, ware cat Anto filne, ent god, and tho elometion, tansilo etrongth. and unextretablo at failure determinod. It was neosany to determine the longth of a thering oyolo which would offectively

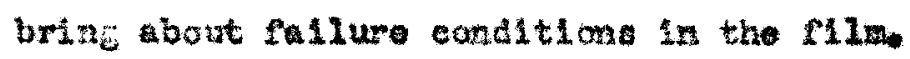

Typical saxplos wo seleoted irom the entira group (Table 1) and the physionl properties of these forsulations were sullad

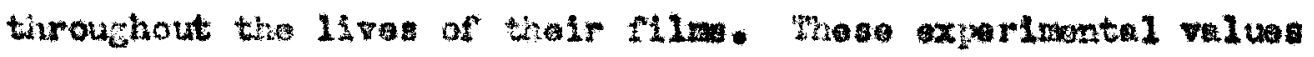

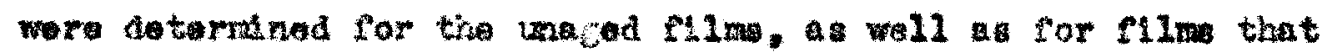

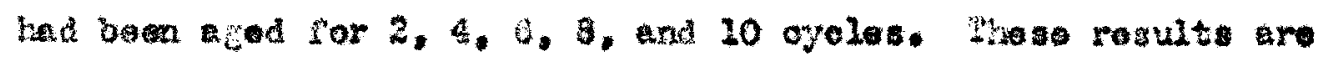
ton 2 in Table II.

Tho resulta fron in this tablo wore calculatod irom tho

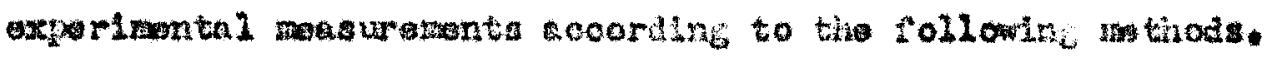

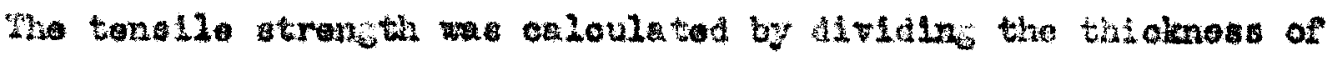
the flu in inches, wasurad by tho morometer, into the

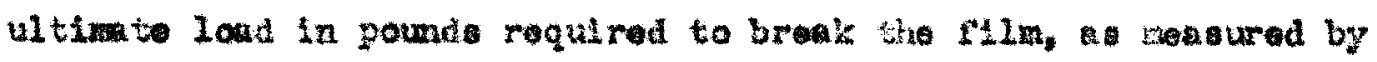
the soot tester. SInce the fin stripo were out ane inoh wide

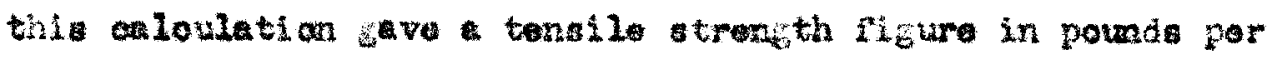

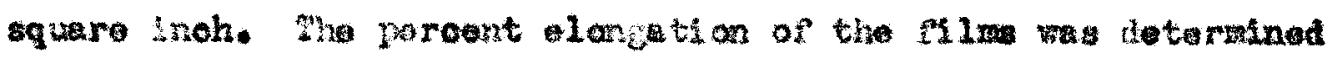

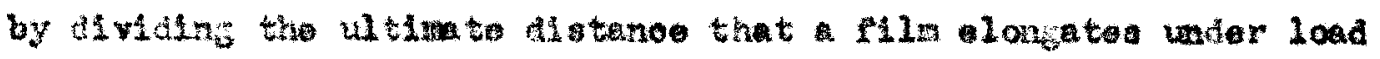

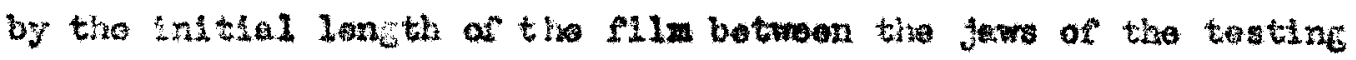

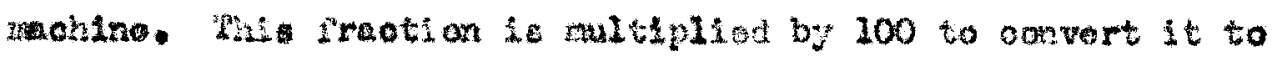
poreant. 


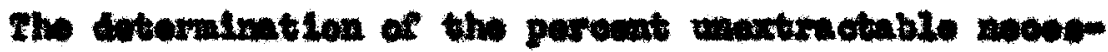

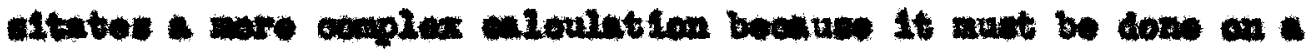

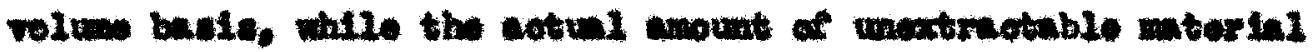

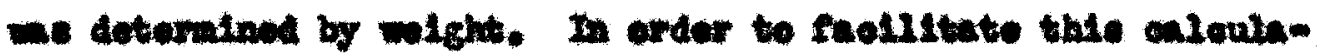
tion a formula we eoviopod at followas

To convert rrem wight to rolve bate the might fectore nut

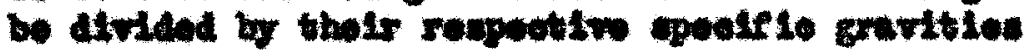

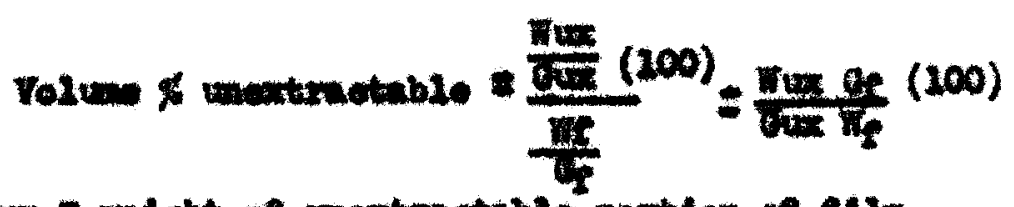

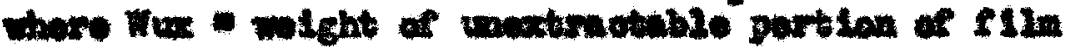

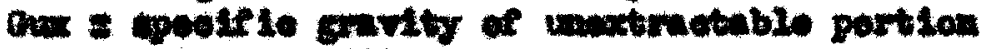

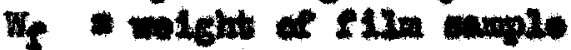

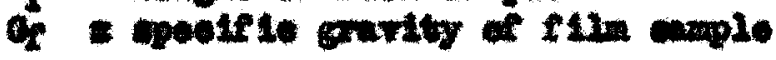

The wight quantitien in (2) are monowed eqperimantally, but

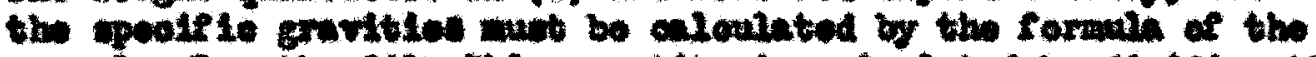

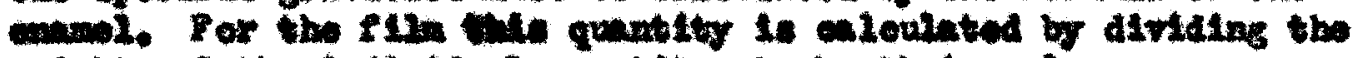

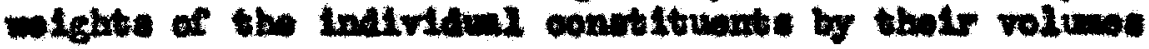

$$
c_{2}=\frac{\text { Town }}{\text { Totrotp }}
$$

If It Is aterumed that all of the plganat is rotalinod in the cortrimetion thimble, maling the peotelo grovity of the extruotiblo

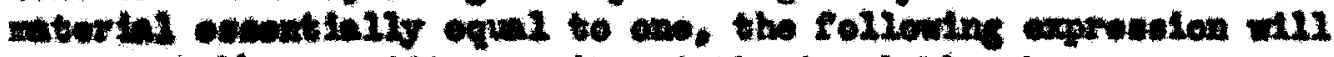

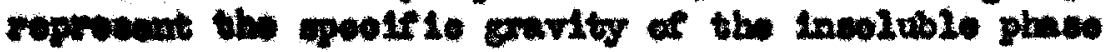

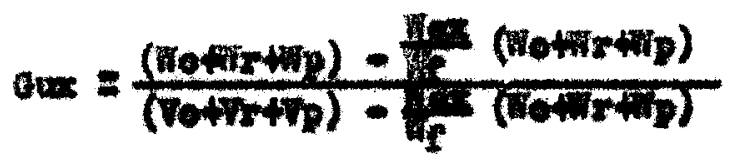

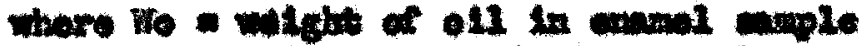

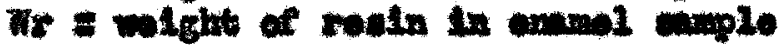

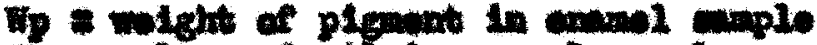

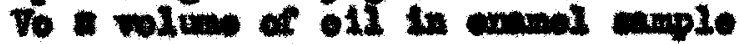

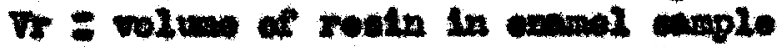

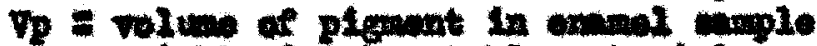

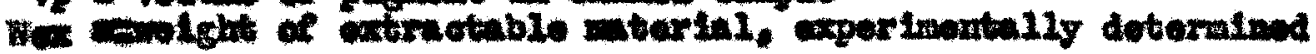




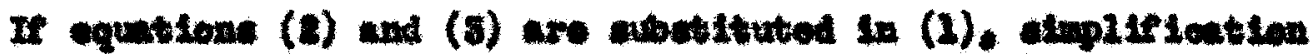

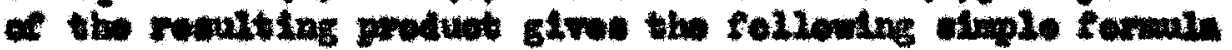

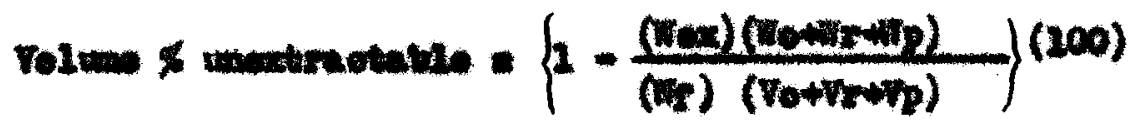

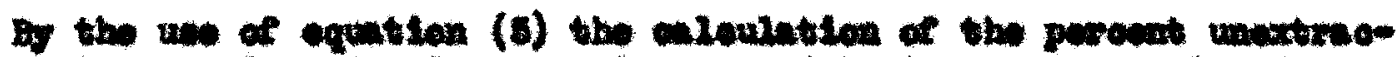

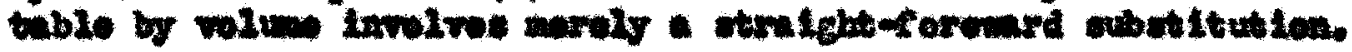

Th reaulte thom in Fuble II are plotted in rigures o to 11.

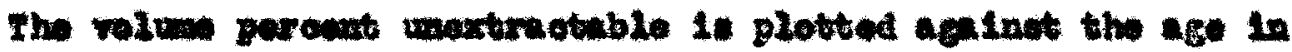
gyoten and the elonetion in porenat. Thew ourres are rory olmular to these plotted by trat and Lubbers (4) for olear

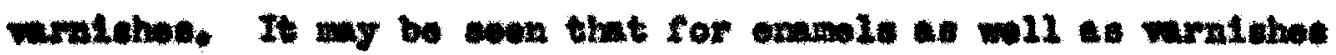

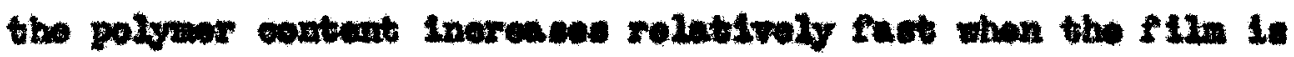
young, but appromehne a conotwent wine an agtug continuse, In all

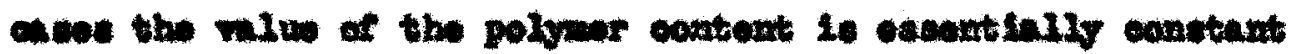

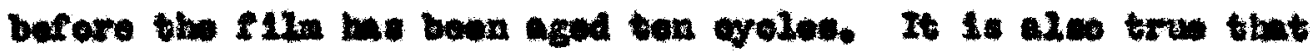

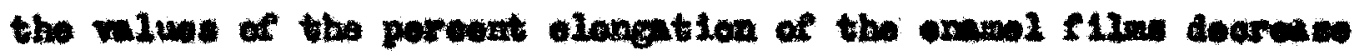

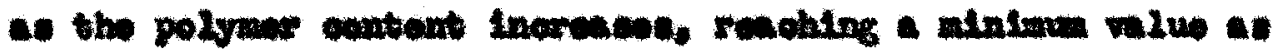

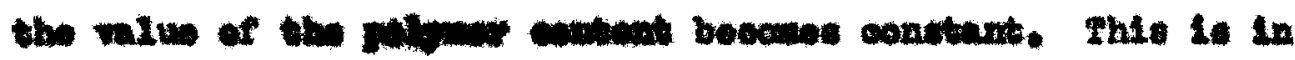

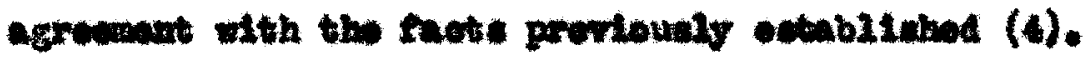




\section{TABS II}

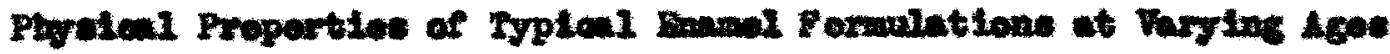

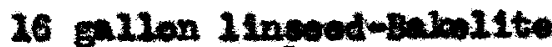
varnith with $\frac{1}{2}$ the roaln repleow with $\mathrm{THO}_{2}$

16 galen tuag-boltte varith wth the rosin replanod with BCWL

16 gulon 1 ingeedroxter gum

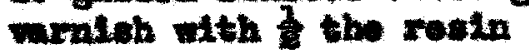
replineod with $\mathrm{FuOHO}_{4}$

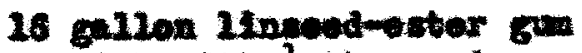
mratch ith $\frac{1}{2}$ the realn replaow with $\mathrm{P}$ og $\mathrm{O}_{3}$

35 gillow Iingoed-oater gum varnith ith the resin roplawed with $\mathrm{r}^{20}$

os gallon 1ingeod-Babelito wrrnish with 1 the rosin ropleoed wth BCWL
Docertption of sumple

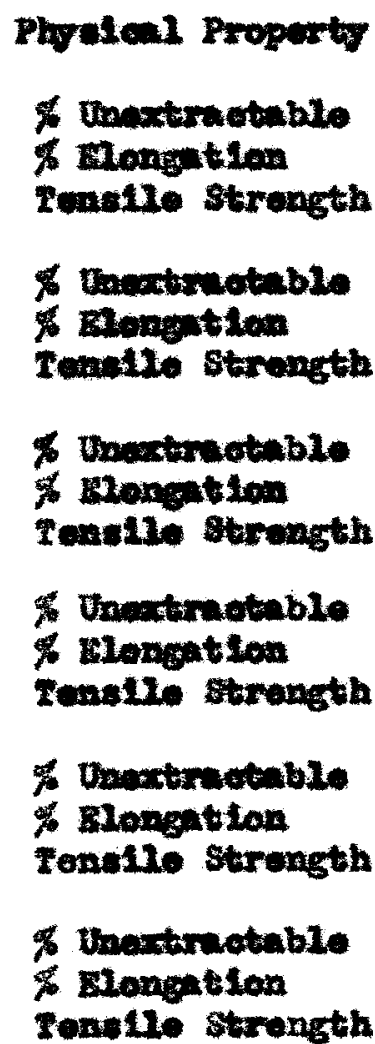

*an Indleted that the fllm we too pisetio to pull

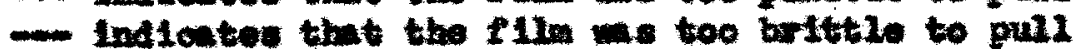

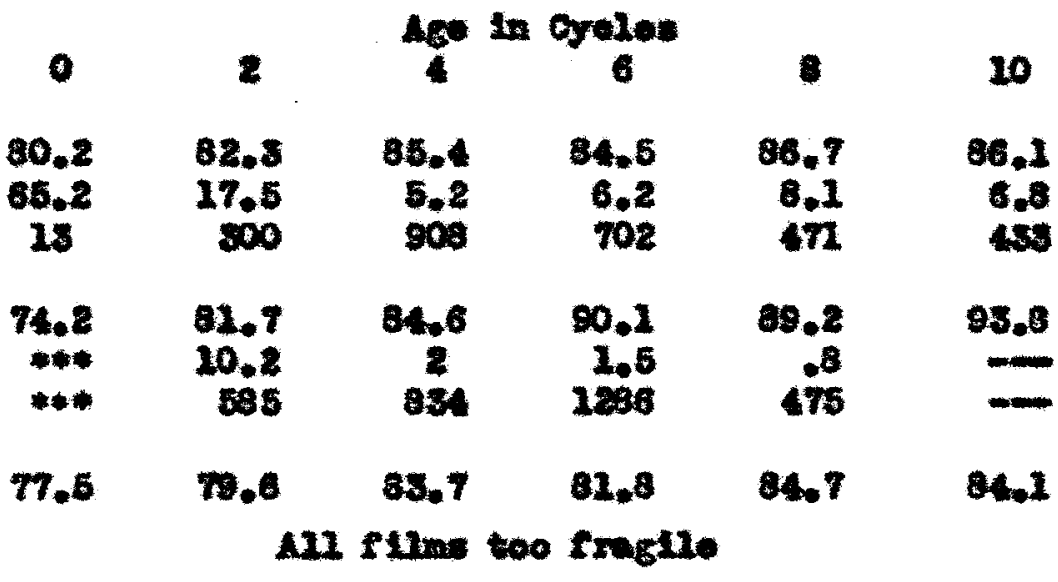

$\begin{array}{llllll}79.8 & 74.1 & 84.2 & 83.8 & 89.2 & 06.2\end{array}$ Alx flime too froglie

\begin{tabular}{|c|c|c|c|c|c|}
\hline $\begin{array}{c}58.8 \\
67.8 \\
0\end{array}$ & $\begin{array}{c}68.2 \\
17.3 \\
20\end{array}$ & $\begin{array}{c}66.8 \\
59.6 \\
0\end{array}$ & $\begin{array}{c}76.0 \\
18.2 \\
0\end{array}$ & $\begin{array}{c}67.8 \\
21.1 \\
0\end{array}$ & $\begin{array}{c}0.5 \\
14.4 \\
0\end{array}$ \\
\hline $\begin{array}{r}76.8 \\
52.4 \\
105\end{array}$ & $\begin{array}{r}76.6 \\
19.1 \\
380\end{array}$ & $\begin{array}{r}82.7 \\
6.6 \\
848\end{array}$ & $\begin{array}{r}7.0 \\
5.9 \\
1160\end{array}$ & $\begin{array}{r}08.5 \\
1.9 \\
505\end{array}$ & 88.0 \\
\hline
\end{tabular}




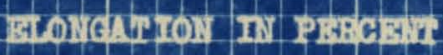

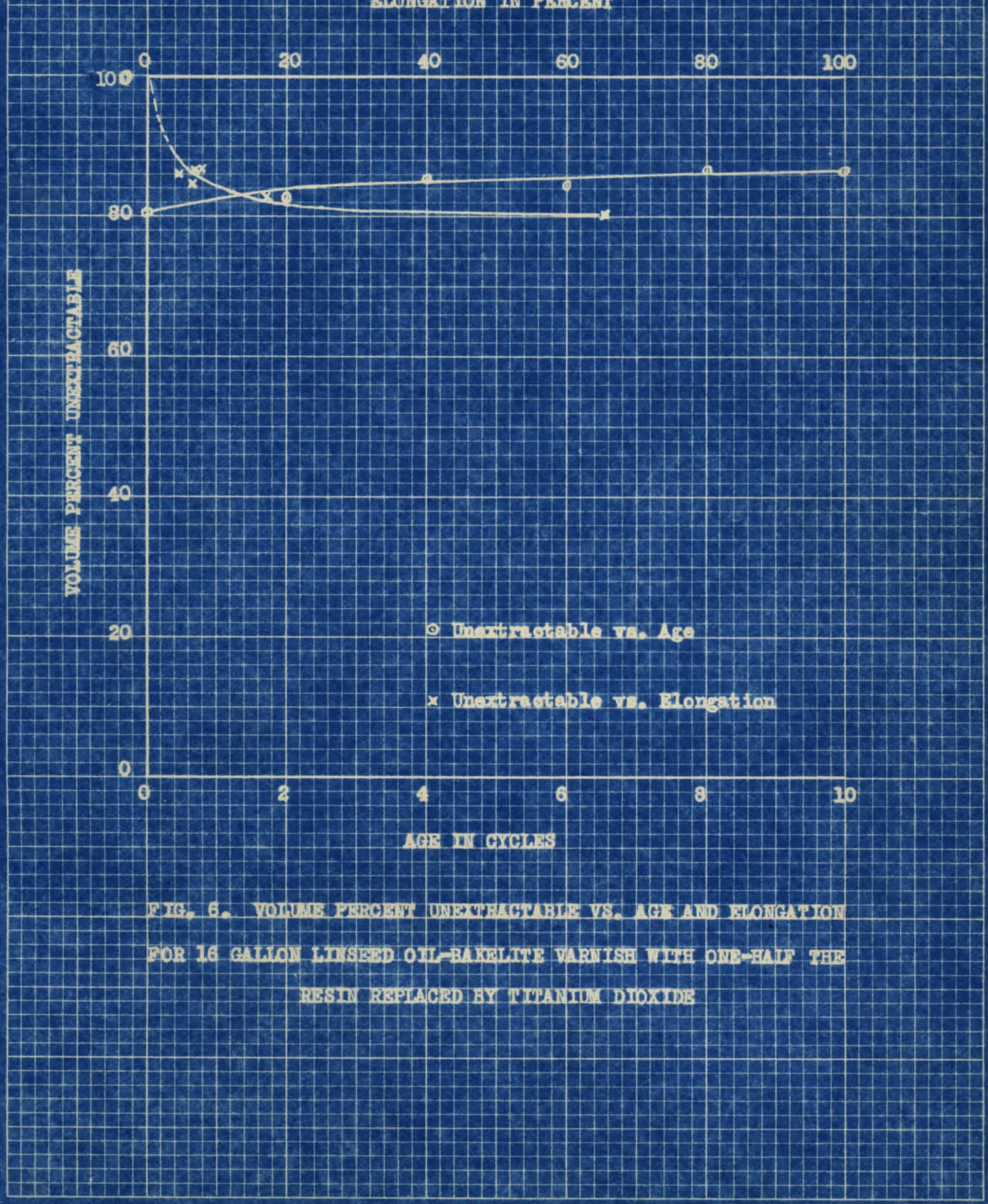




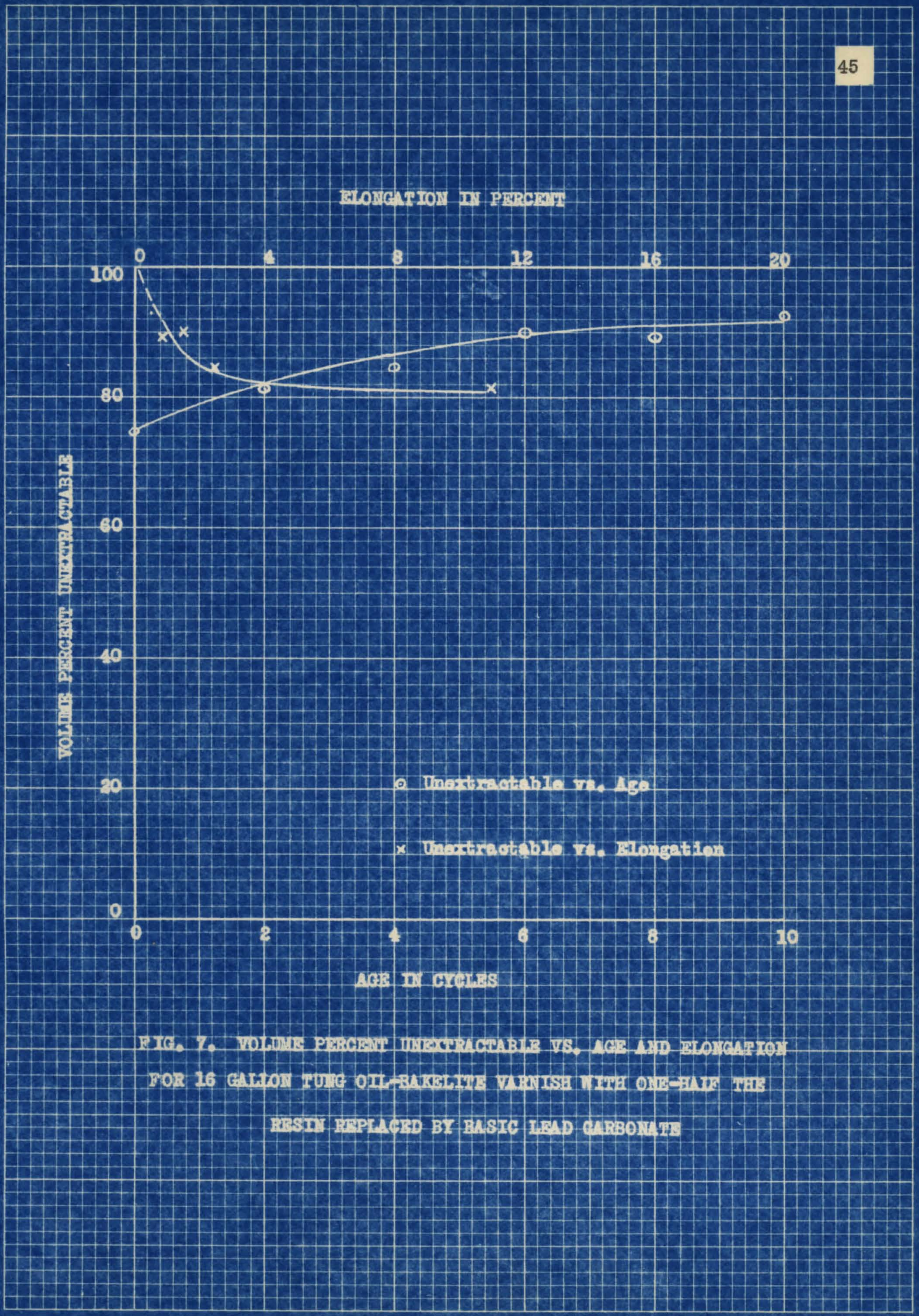




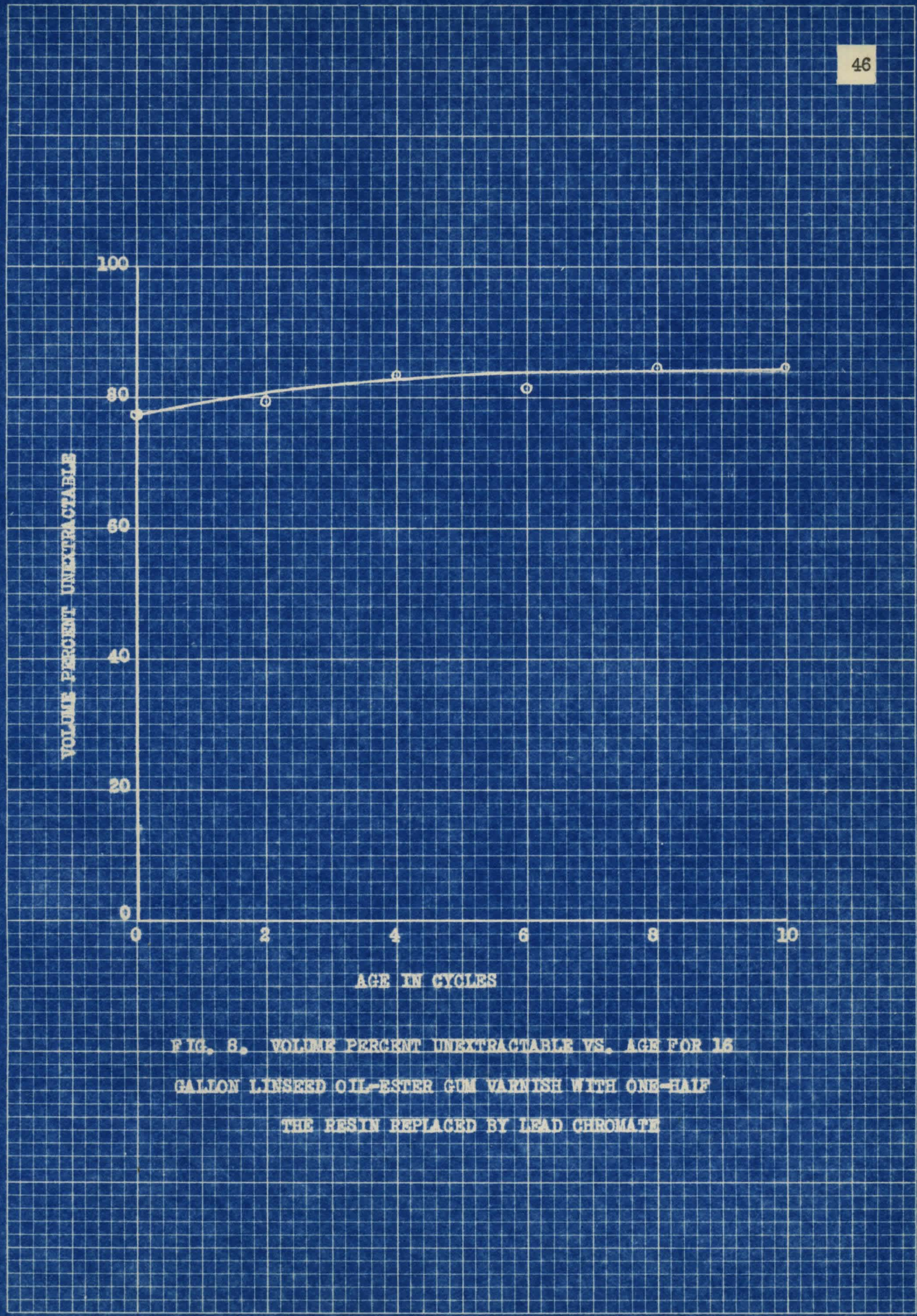




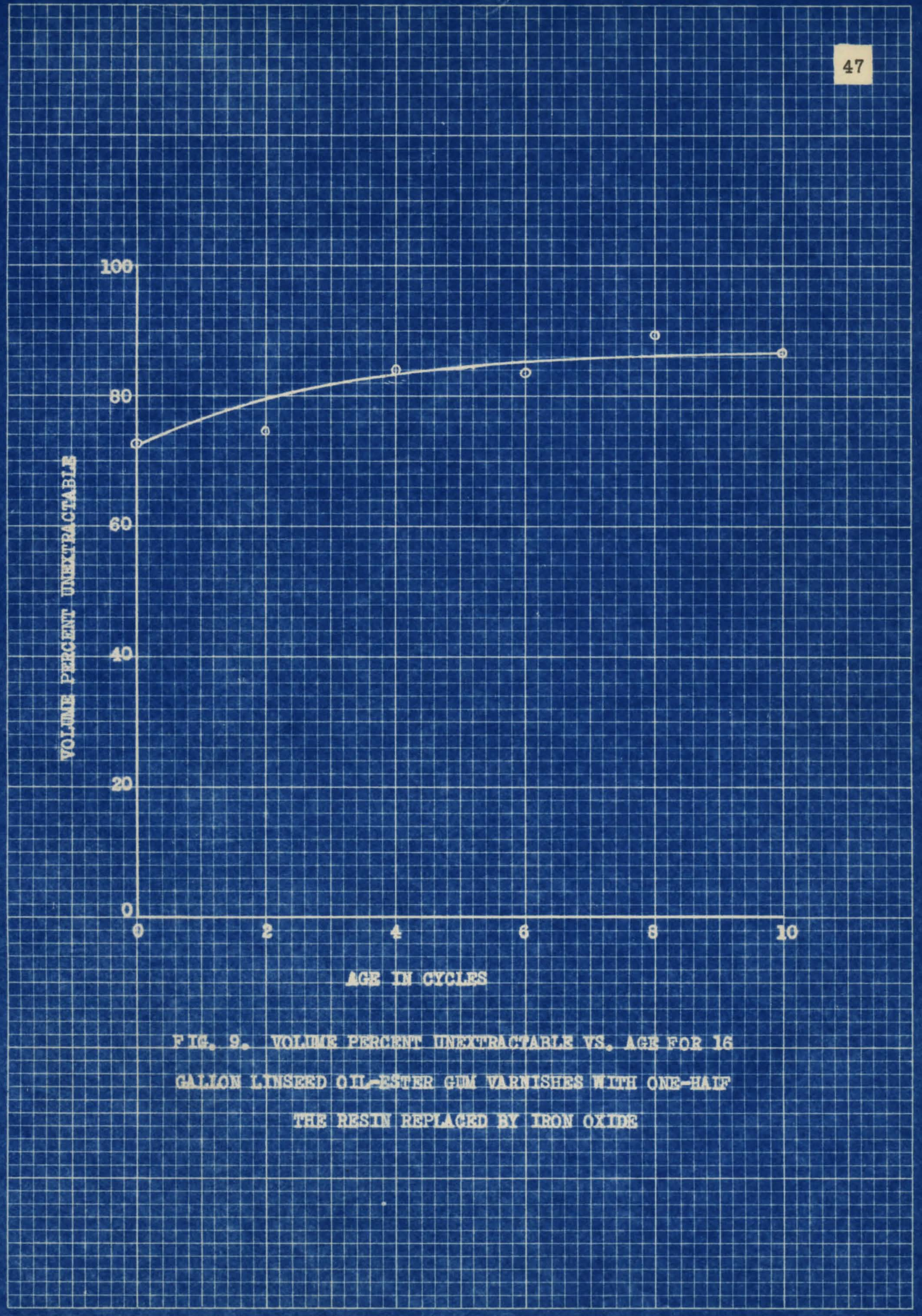




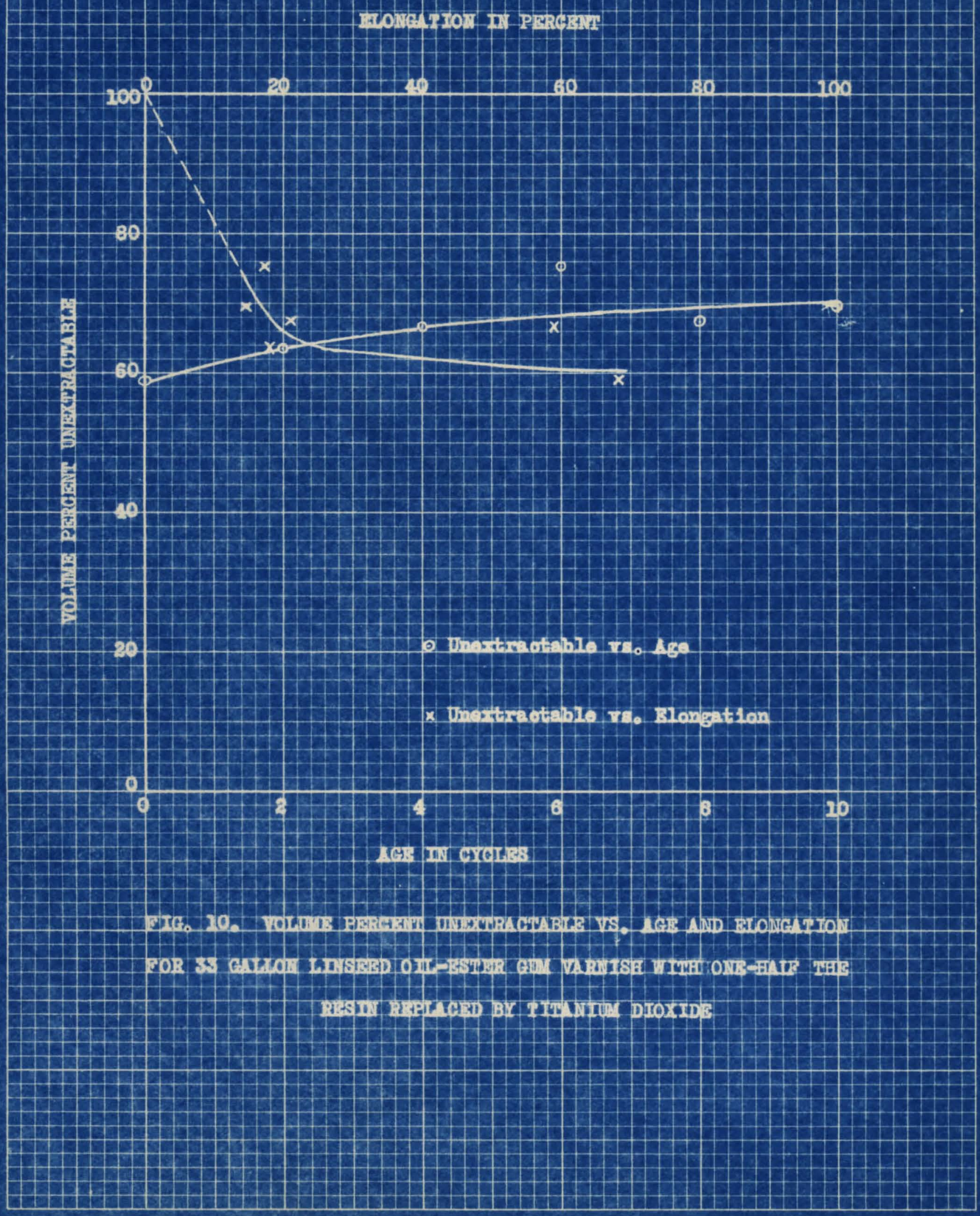




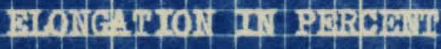

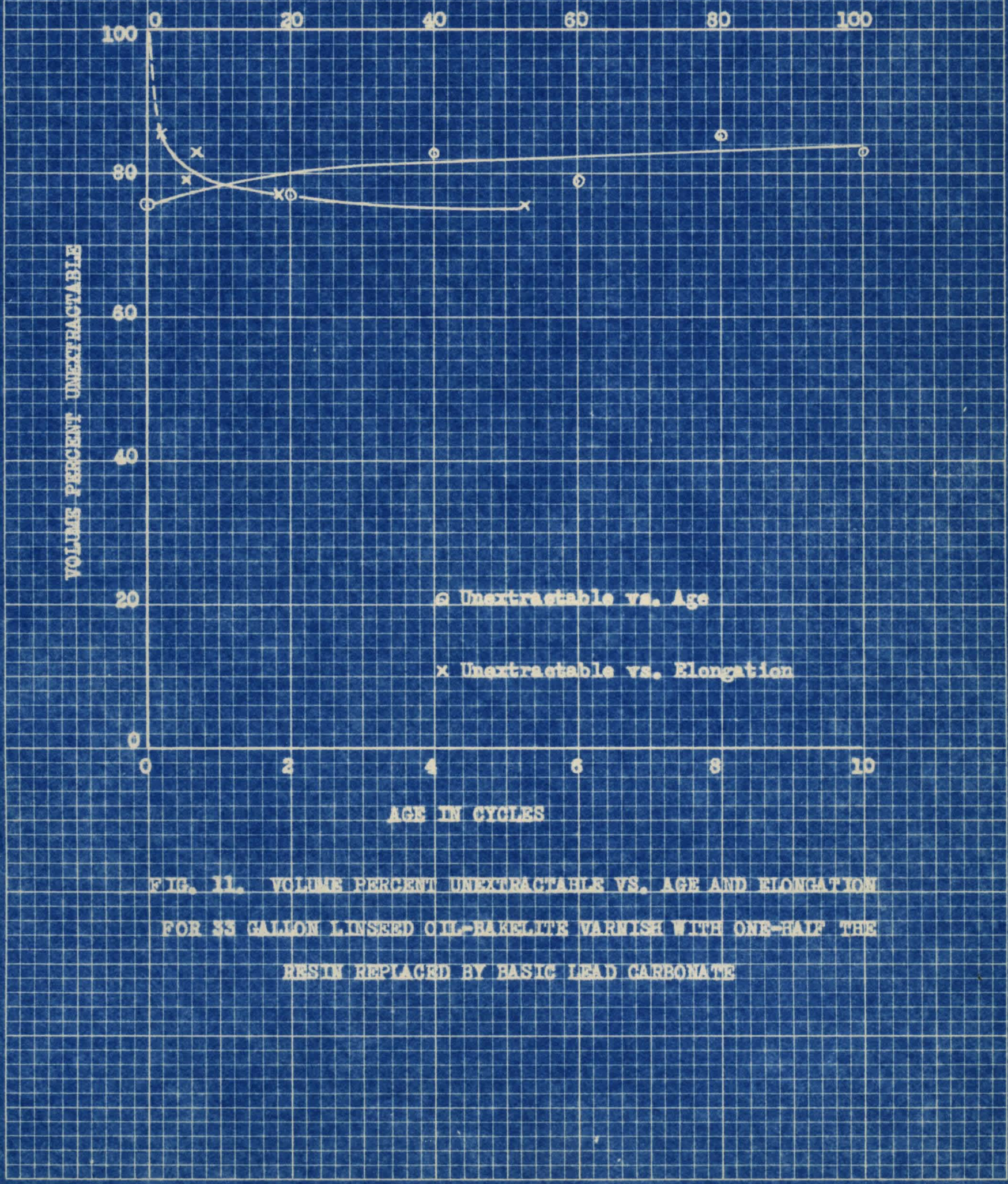


Since the values shown in the procedint ourves for porcent moxtractablo beoom esaentially combant boforo the flim ha ajod 10 oyolos, It la sefe to any the tho polymer contont of en enanel ilm at failure ia osentially oqual to

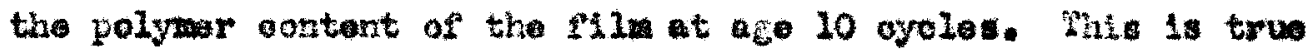
oven if vialblo failure has not courrod ofter the filn wa beon ased 10 oyoles, which was the nore frequent caes. A fow of the film falled as orly oyelos, but noot of thom fallod at 10 or more.

Fran these rosults it was coneluded thet frlluro ocaattione could bo effectively obtained nerely by aing the film for 10 oyeles.

Wow the the effeot of pigntar an the polymerization

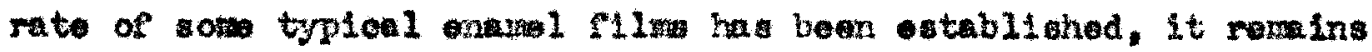

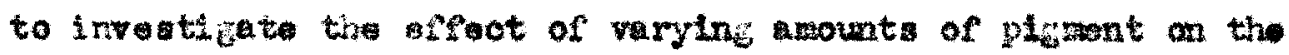
total polyor that he ultimetely corme in a flim won failuro ocours. This wa done by wathering cilas oat from tho formala-

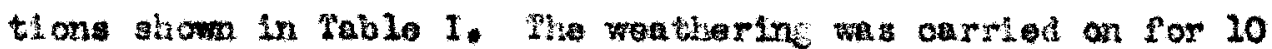

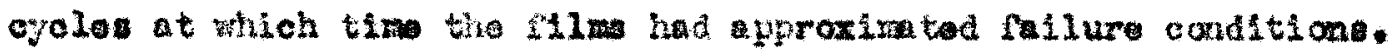

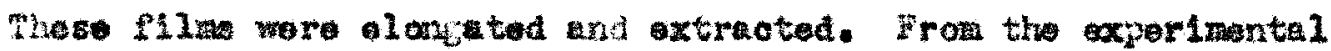
raedng thus obtainod the values of the peroent wextratabla,

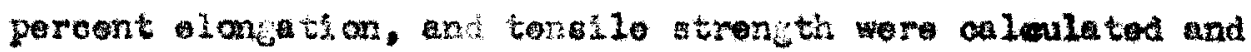
reoorded in rablo III. 
Phreleal Proportion of AlI FIIme at Tan Croles Ag*

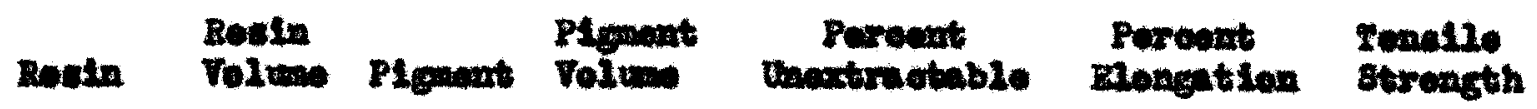
16 allon 1 ingoed oll rarnighes:

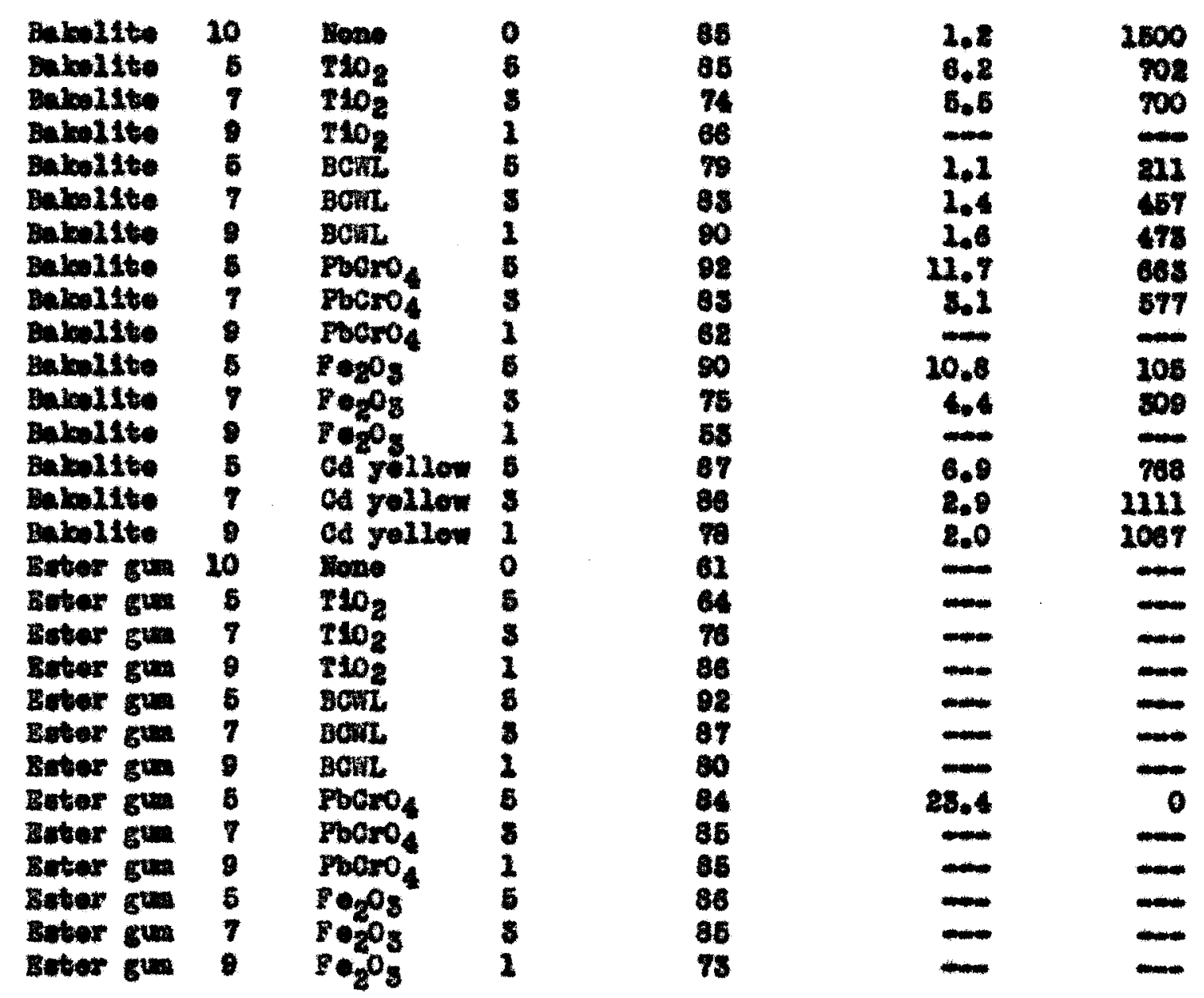

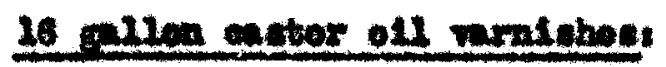

\begin{tabular}{|c|c|c|c|c|c|c|}
\hline 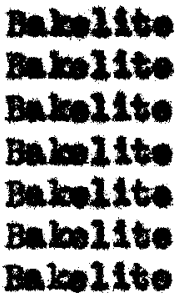 & $\begin{array}{r}20 \\
5 \\
7 \\
9 \\
5 \\
7 \\
8\end{array}$ & 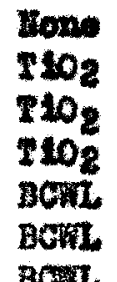 & $\begin{array}{l}0 \\
5 \\
3 \\
1 \\
5 \\
8\end{array}$ & $\begin{array}{l}92 \\
98 \\
90 \\
89 \\
91 \\
90 \\
98\end{array}$ & $\begin{array}{r}2.8 \\
9.7 \\
8.7 \\
4.8 \\
2.8 \\
20.1 \\
0.8\end{array}$ & $\begin{array}{l}2090 \\
1051 \\
1297 \\
1818 \\
1852 \\
2098 \\
1995\end{array}$ \\
\hline
\end{tabular}




\section{TABS III (oontimuad)}

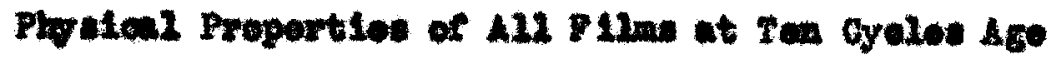

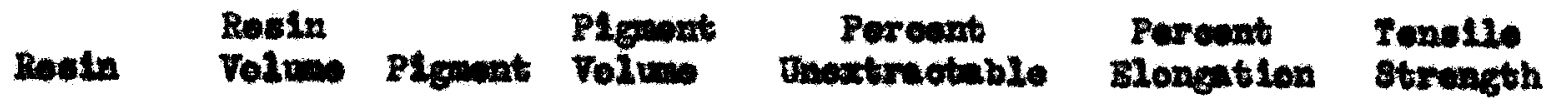

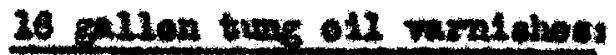

\begin{tabular}{|c|c|c|c|c|c|c|}
\hline 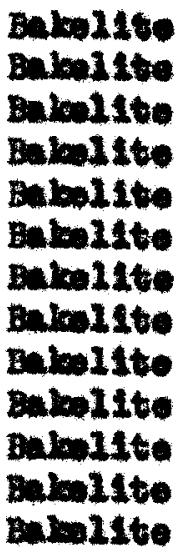 & $\begin{array}{l}10 \\
5 \\
7 \\
9 \\
5 \\
7 \\
9 \\
6 \\
7 \\
6 \\
5 \\
7 \\
7\end{array}$ & 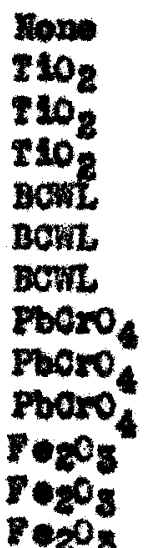 & $\begin{array}{l}0 \\
6 \\
8 \\
2 \\
8 \\
8 \\
1 \\
6 \\
8 \\
1 \\
5 \\
8 \\
1\end{array}$ & $\begin{array}{l}98 \\
98 \\
08 \\
88 \\
00 \\
88 \\
78 \\
92 \\
88 \\
78 \\
88 \\
85 \\
78\end{array}$ & $\begin{array}{l}1.6 \\
8.7 \\
2.0 \\
1.6 \\
2.8 \\
2.4 \\
2.6 \\
2.6 \\
0.6 \\
1.8 \\
5.8 \\
8.4 \\
0.8\end{array}$ & $\begin{array}{r}600 \\
1000 \\
1210 \\
104 \\
684 \\
1009 \\
679 \\
767 \\
108 \\
200 \\
1089 \\
1042 \\
188\end{array}$ \\
\hline
\end{tabular}

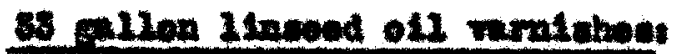

\begin{tabular}{|c|c|c|c|c|c|c|}
\hline 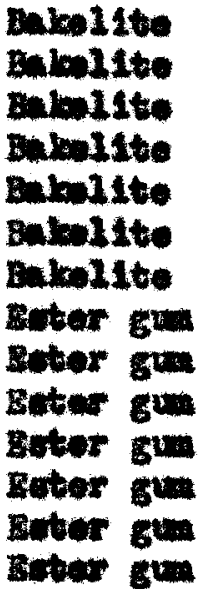 & $\begin{array}{r}20 \\
6 \\
7 \\
9 \\
6 \\
7 \\
9 \\
10 \\
6 \\
7 \\
6 \\
5 \\
7 \\
9\end{array}$ & 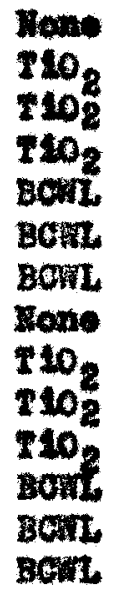 & $\begin{array}{l}0 \\
8 \\
3 \\
1 \\
6 \\
3 \\
1 \\
0 \\
6 \\
8 \\
1 \\
8 \\
3 \\
1\end{array}$ & $\begin{array}{l}90 \\
90 \\
90 \\
84 \\
88 \\
88 \\
90 \\
70 \\
68 \\
71 \\
75 \\
80 \\
78 \\
78\end{array}$ & $\begin{array}{r}2.6 \\
11.6 \\
11.8 \\
3.7 \\
2.0 \\
1.6 \\
8.6 \\
1.0 \\
2.1 \\
1.4 \\
0.6 \\
=-\end{array}$ & $\begin{array}{r}1775 \\
501 \\
752 \\
1860 \\
570 \\
1146 \\
1114 \\
24 \\
0 \\
8 \\
20 \\
-\end{array}$ \\
\hline
\end{tabular}

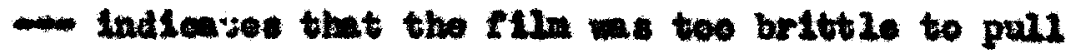


The date in feble III inolude lve for the poroent unoxtmotable at fallure for olear varniahos and enumblo havinc piguaterealn volummratios of $1 / 9,8 / 7$, and $5 / 5$. This 61 vos

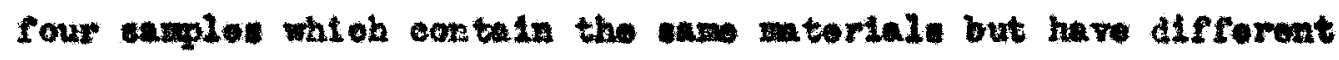
pLgant concentruti ar. The viluse of the polymor oontent at fallure wore plotted adainat the peroentage of realn in the

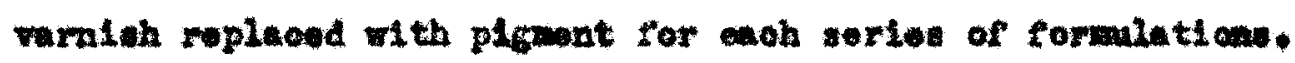
These ourves are bom in figuree 12 to 21.

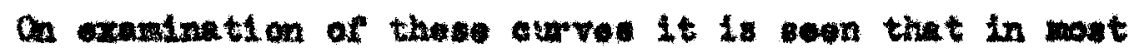

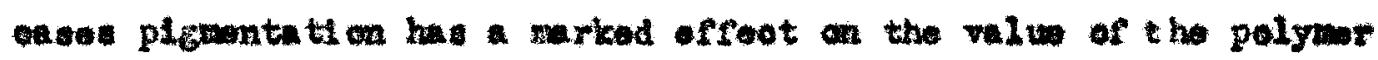
content of the varnith at rallure, eapecially at lom plgront conoentrats ana.

Constder the Linsead-eter gum in both the 16 and $58 \mathrm{gallem}$ ofl longths, flgure 12 and 13 . The effect of besto

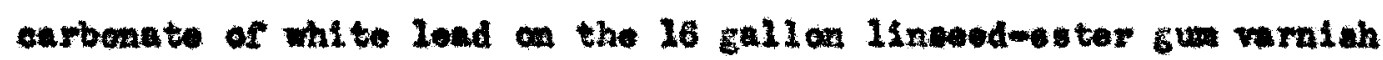
Is to eaute the polymor content at fallure to Inereace as the

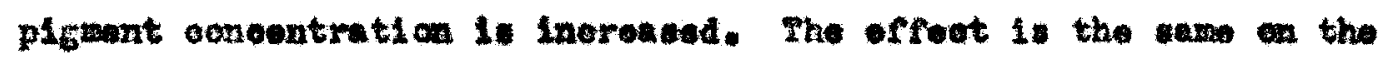

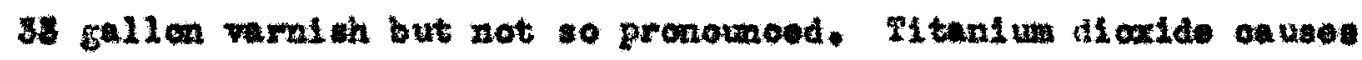

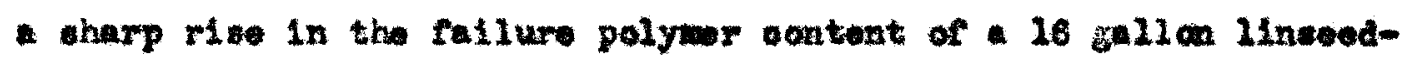

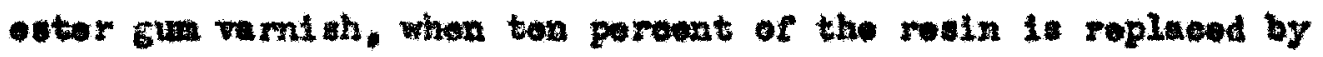

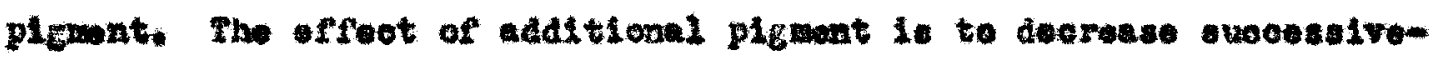
Iy the ultimate polymer unt11 it is oteventilly oqual to thet of

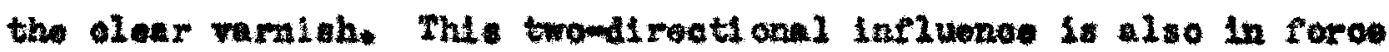
cu stilen varnishos, but to lesser dogreo. Who rosen tho 


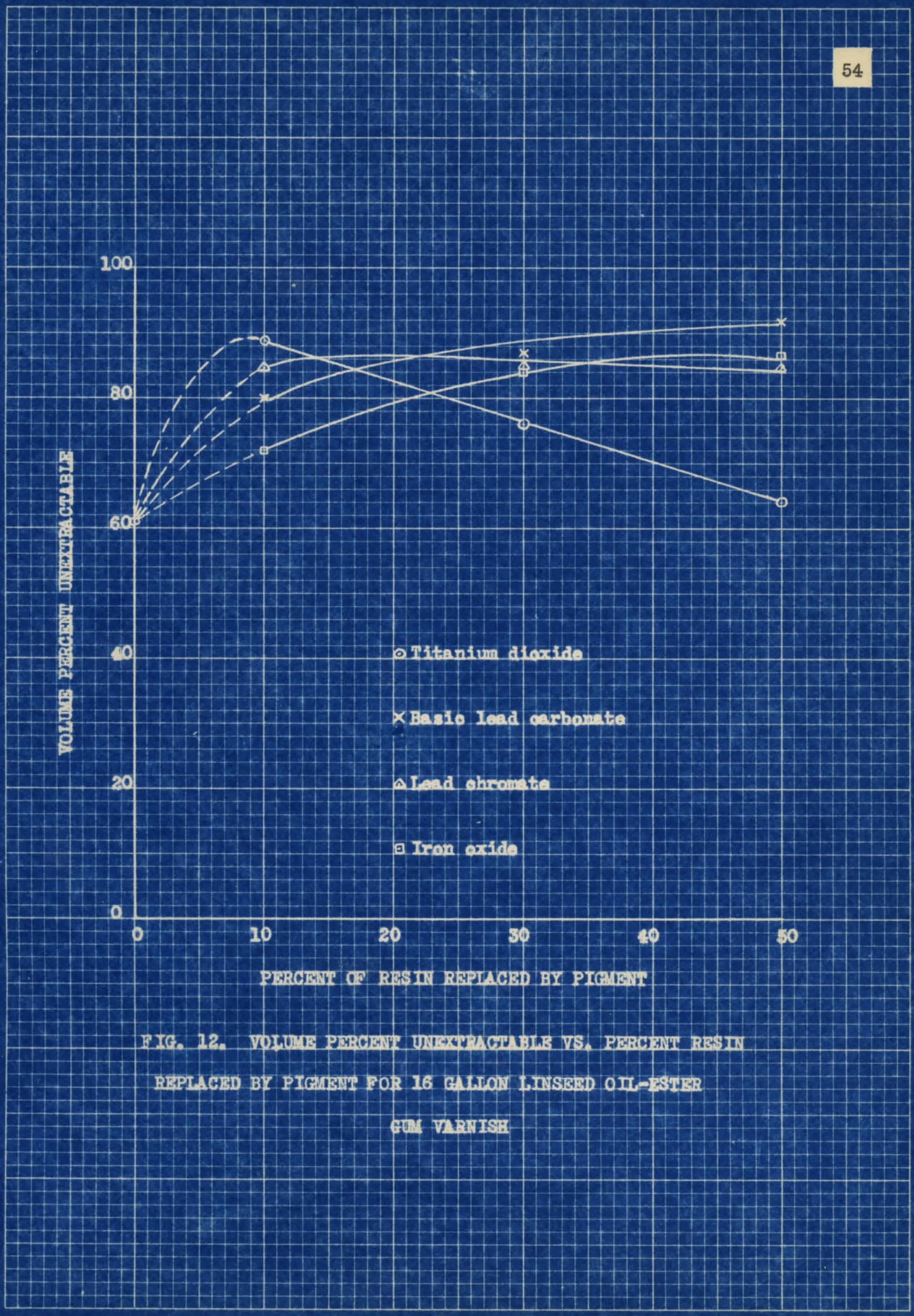




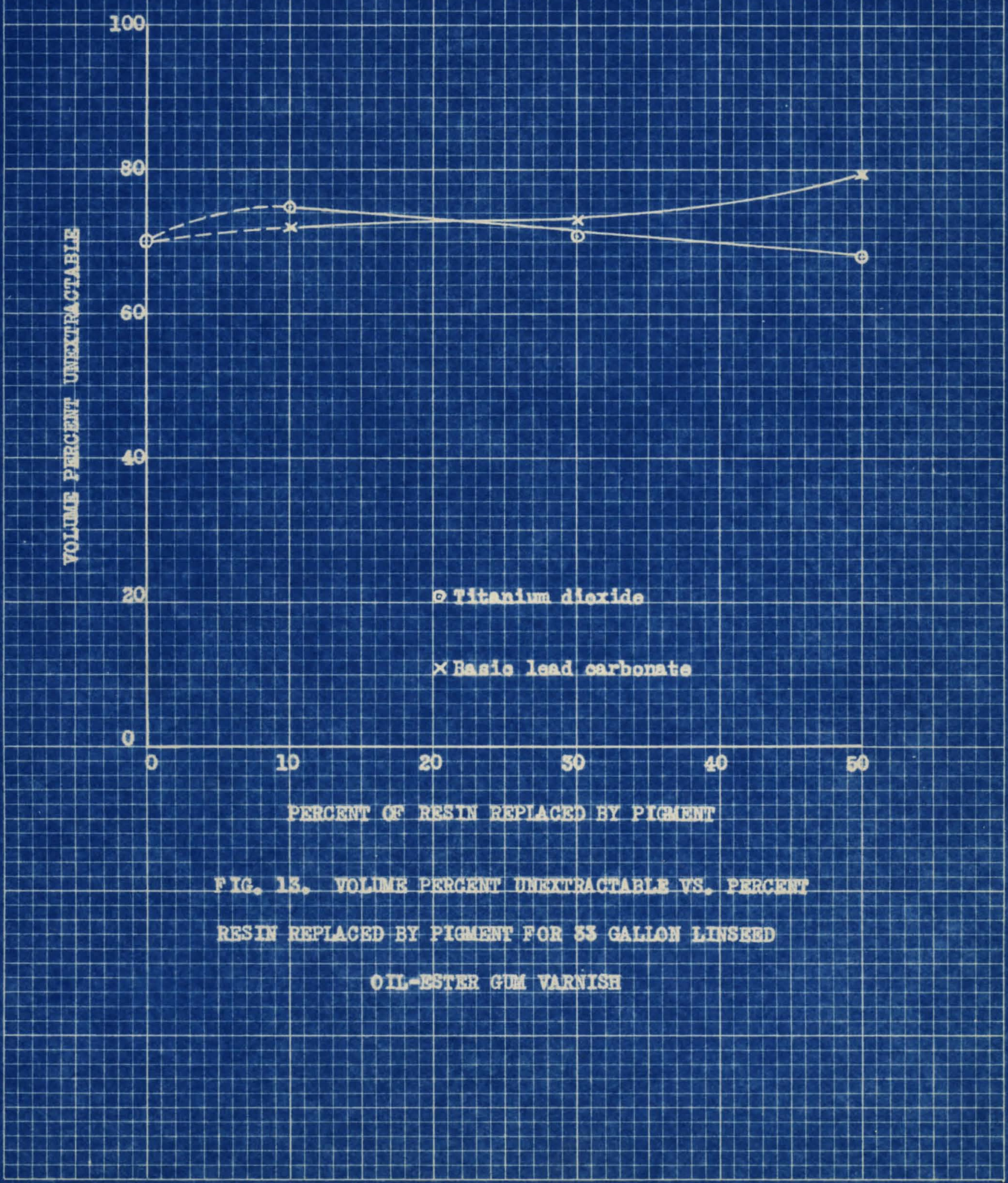




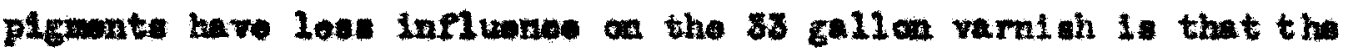
rouln-plgmot portion of the filw formed from 88 gnll on onami

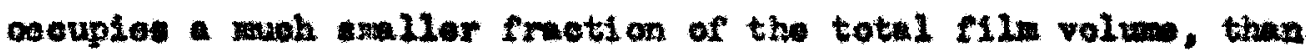

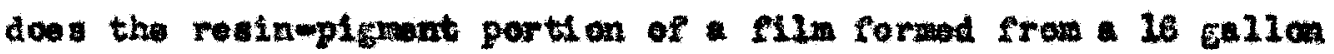
emanel.

The reault of Agurea 12 and 18 show that the oubstitution of ballo lead onrbetate in a varnish formation bring: about suopeseive ineronaes in the polymar content at fellure. This sould bo due to a catlytio offect of balis load carbonate to promote polymorisuta on to the formation of Insolublo lead eap with the fres cota in the ofl or a oalition between the lead ourbonte and the triglyeoride radiond. inad ohrome and Iren oxide have the angio offect but to a sightly leser dogroe. The all three of these plgmente are all-routive undoubtedly is

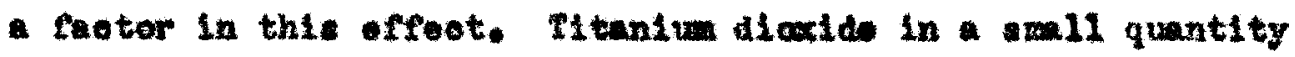
oused the poreent mextractable et fallure of linseod-anter sua varuishes to be inoreased. Then combulf the resin wa replesed

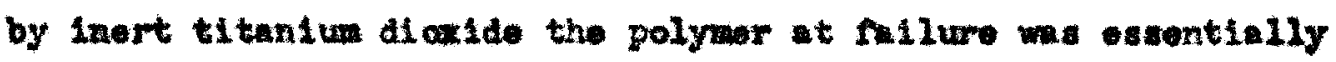
oqual to thet of the eloar varaich. Thi lndionto that titunium

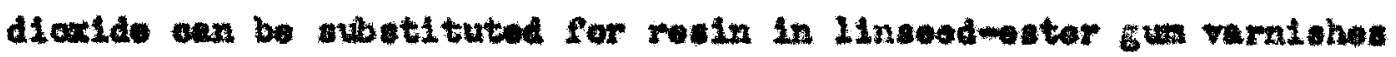

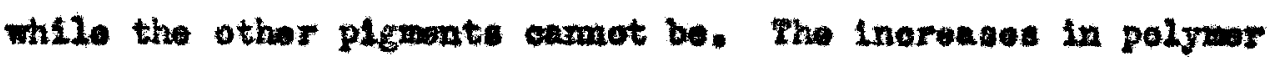
contunt at the lower plgnant conoentrutione were due to the thot that the glgront was not present in amounts large enough to bring bout representative effoet. 


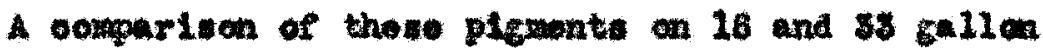

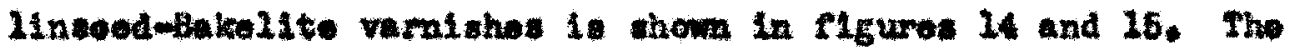
effectil appour to be ruther rarled, but moh wore pronounoed on the 16 gallon vernith than on the 83 gallen varaith. The

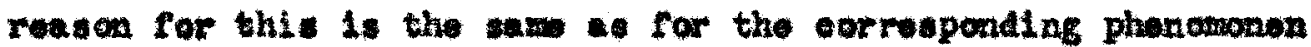

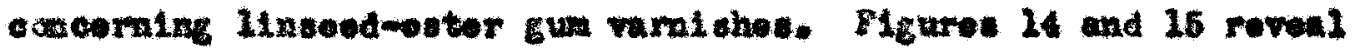

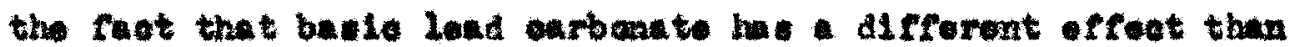
the other pigmonte both the 16 and 35 galla 11 meed-Bula 21 to

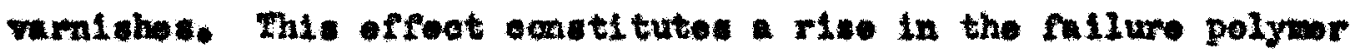
content for camples in which ten peroent of the resin wes replaced

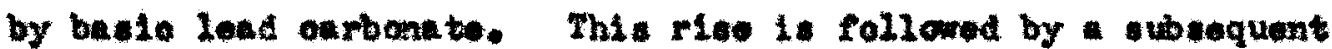

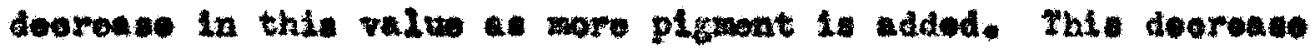
w11 ochelnu wall the fullure-polymer has boow equal to thet of the origlnal olear varnilsh.

The feet of titanlan diaxide in both the 16 and 88

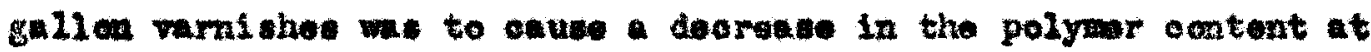
fallure of axple in which ten peroent of the reoth wa replaced

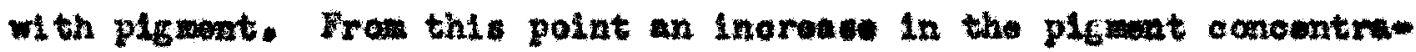
then brought about an inerease in thi. vino to approumbely tho

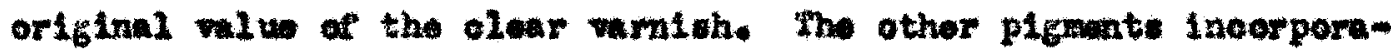

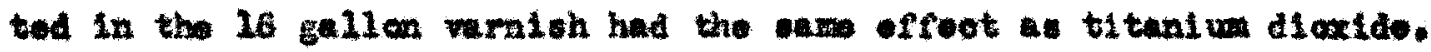
Cadmin sulflde did this to a leser gegreo and Iron oxtde and laad hrowte to sreater degres. The otion of the lond on the 


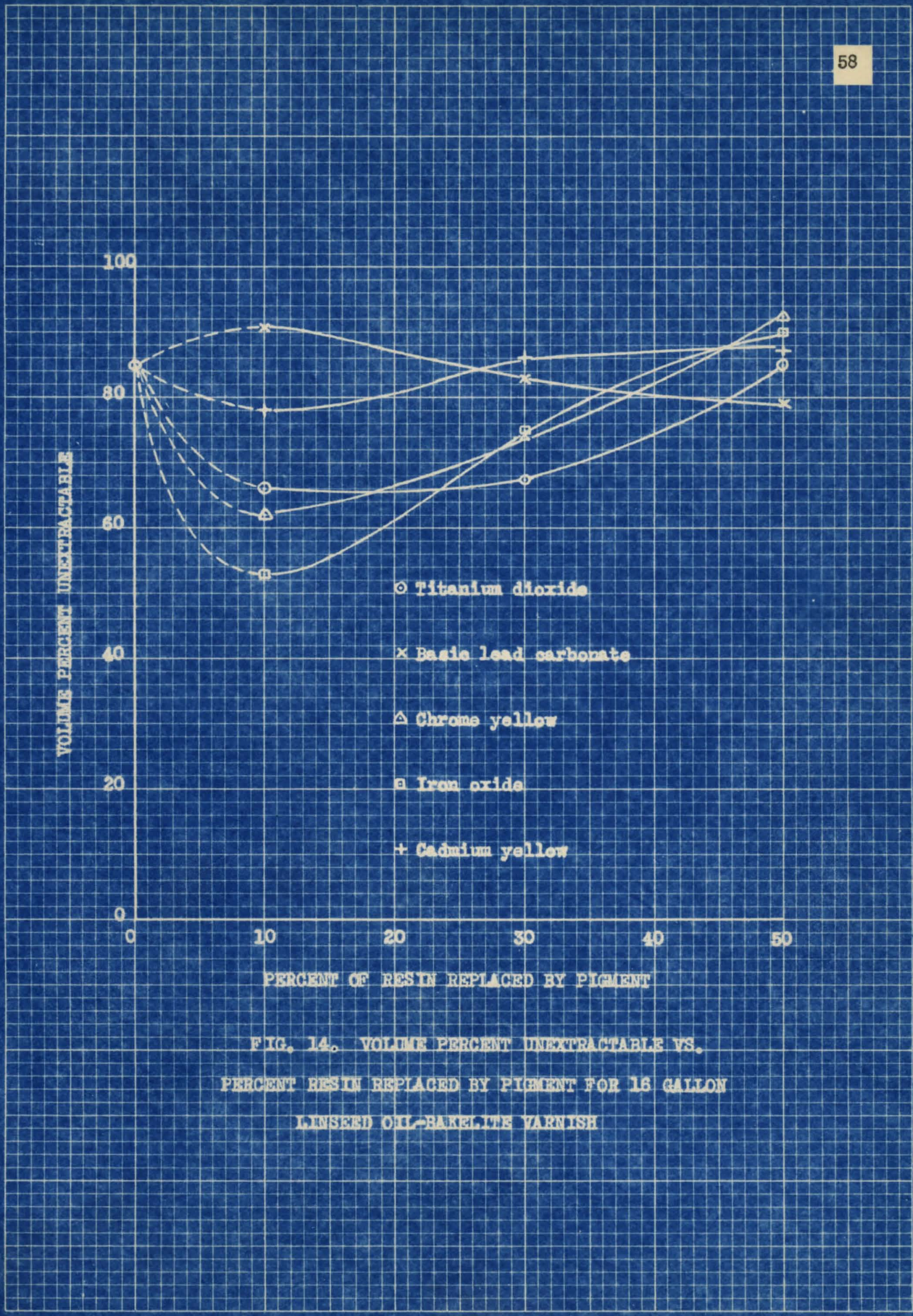




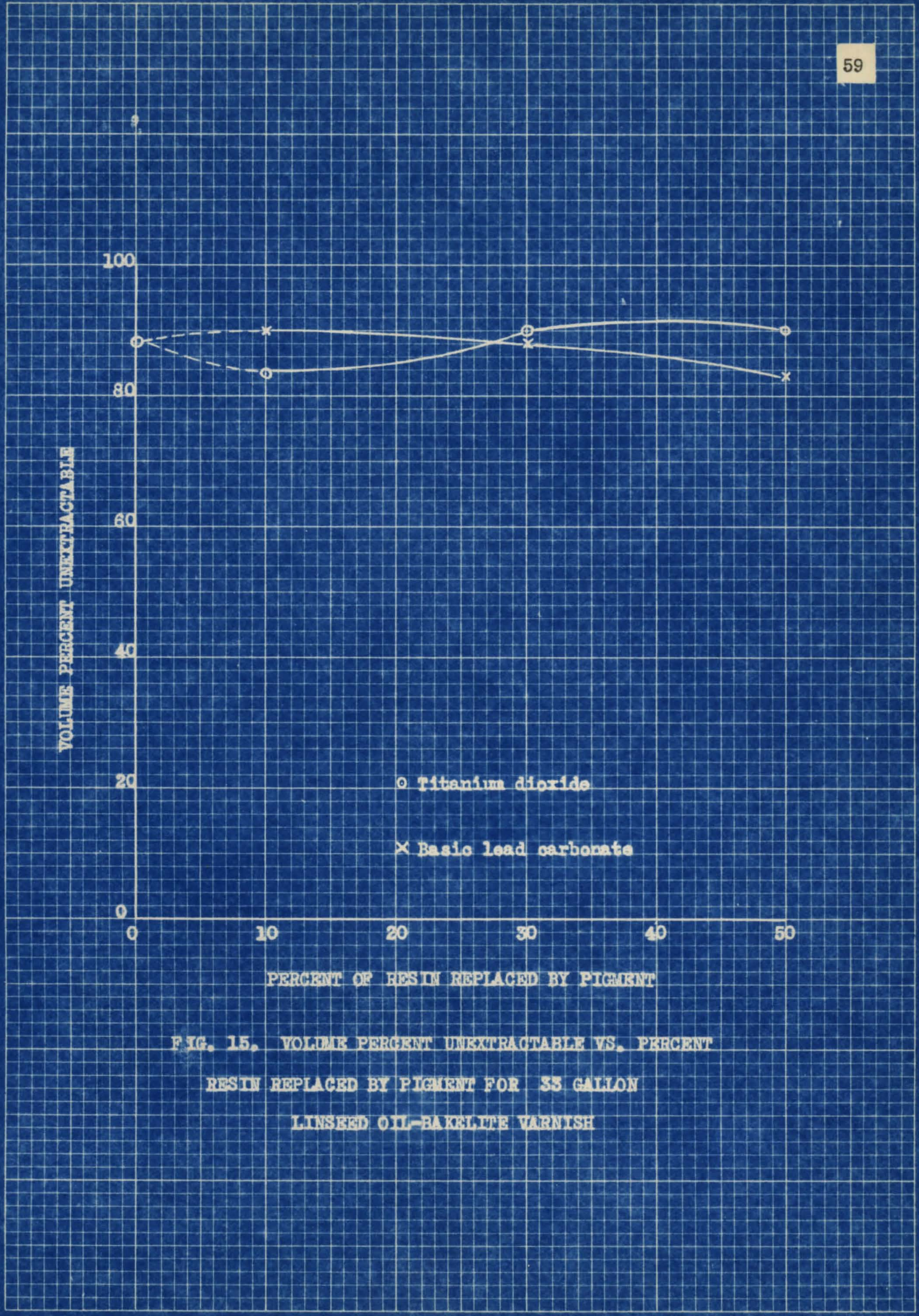




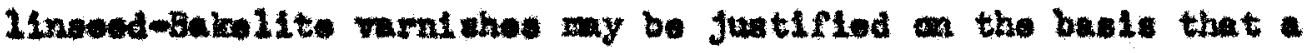

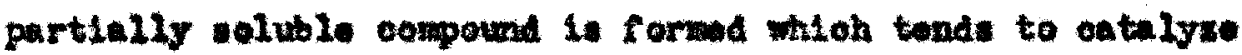
the palymorleation of the rarnieh. Whon the concentration of lond is incrosed boyend oortain point tho colub111ty arfeot of this companad orerahudows 1to ontulyt1o offeot. The not rocult Io a deorenge in the curnt of inooluble material at

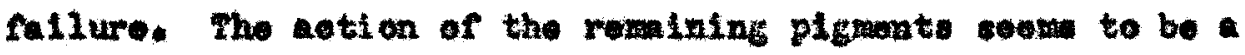

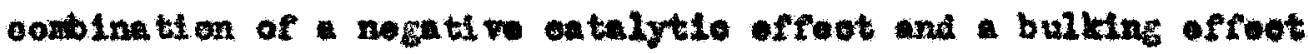
as the pidmont conoontrati inoroween. Thet is, the pigmont

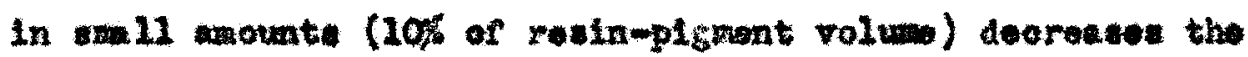
anoust of unextratable mterial at fallure boouse the plgmats hinder the polymeriation of the oll with the resin. he sore plomant is added, whioh is positively an insoluble phase, this

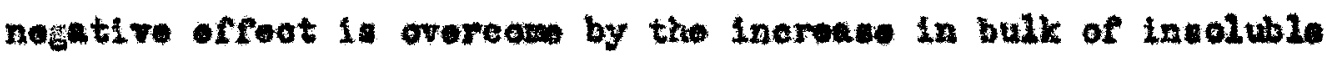
p1gmat. Finelly, it is evident the no mator wat the intermodinte effeots are, the ptgnonts investigetod may bo cubetituted

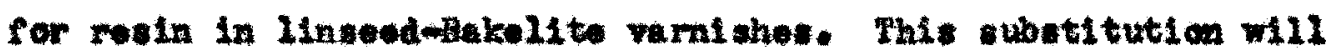
bring about virtully no change in the polymer wontont at fallur. as long as fifty perownt of the reatn is ropleced by plemont. Tho aotion of load carbenate and titaniun dioxide a

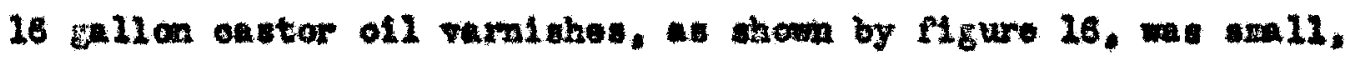
wron at low plement coneantration. In mot, the ourves for those

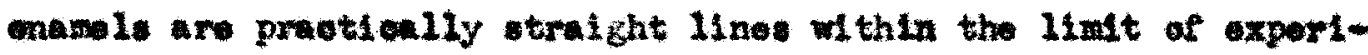
montal orror. It is poetulated thet the plgant Influonos on 


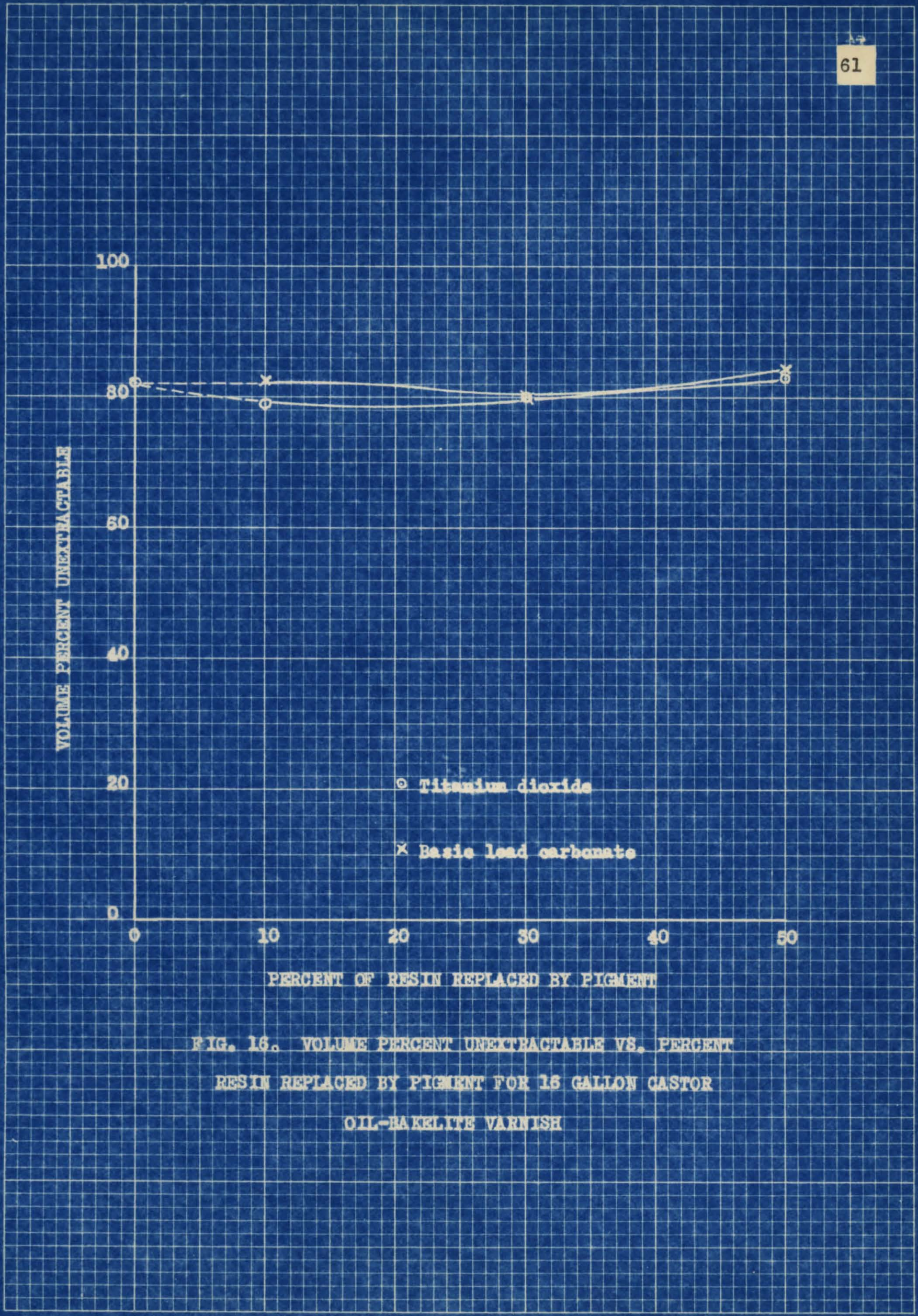


Is gallon cactos oll varnishes would be oven leak. It follow that reain way be replaced by pigmat up to amoute of sifty porcent at leat, In castor oll-Bakellte varal thes, Aooording to figure 17 the antion of titanlum diaclde

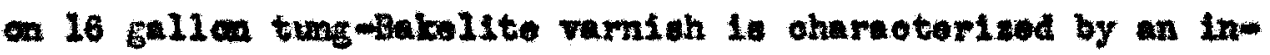
oreace in the polywer oontent at follure for inoroulde additions of the pigment. The rective iren oxlde. ahrow yellow, and load ourbonate 1 we an InItial dearoase to this 11gure. follomed by eubsequent inereaned as more plgate is added. This offeet be due to the ontelytio or autoontalytio formation of soluble compounde, the affeot of which is overoos by the addition of inoolubio bulk afforded by increwed anoumts of plenont. The titanium dlaxide, belng nce-reastive, serves moly to inoreane the bulk of incoluble material. Although the instial effeots are variad, the ultimte vive of the polymor entent, wen onomalf the rosin is roplaced by any of the abow plemente, is equal to that obtalnod for the elear vernioh.

Figure 18 111uvtrates the offect of titaniun alaxide plement on the deforent vehioles that were uad. Figures 19. 20, and 21 show the ano thing for baste load oabonate. loud chromate, and Iran oxide, respetively. The curves for tho land ohrom to and Iron exide pizmonte of the ame genoril shape, regardleas of

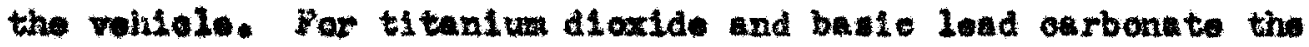




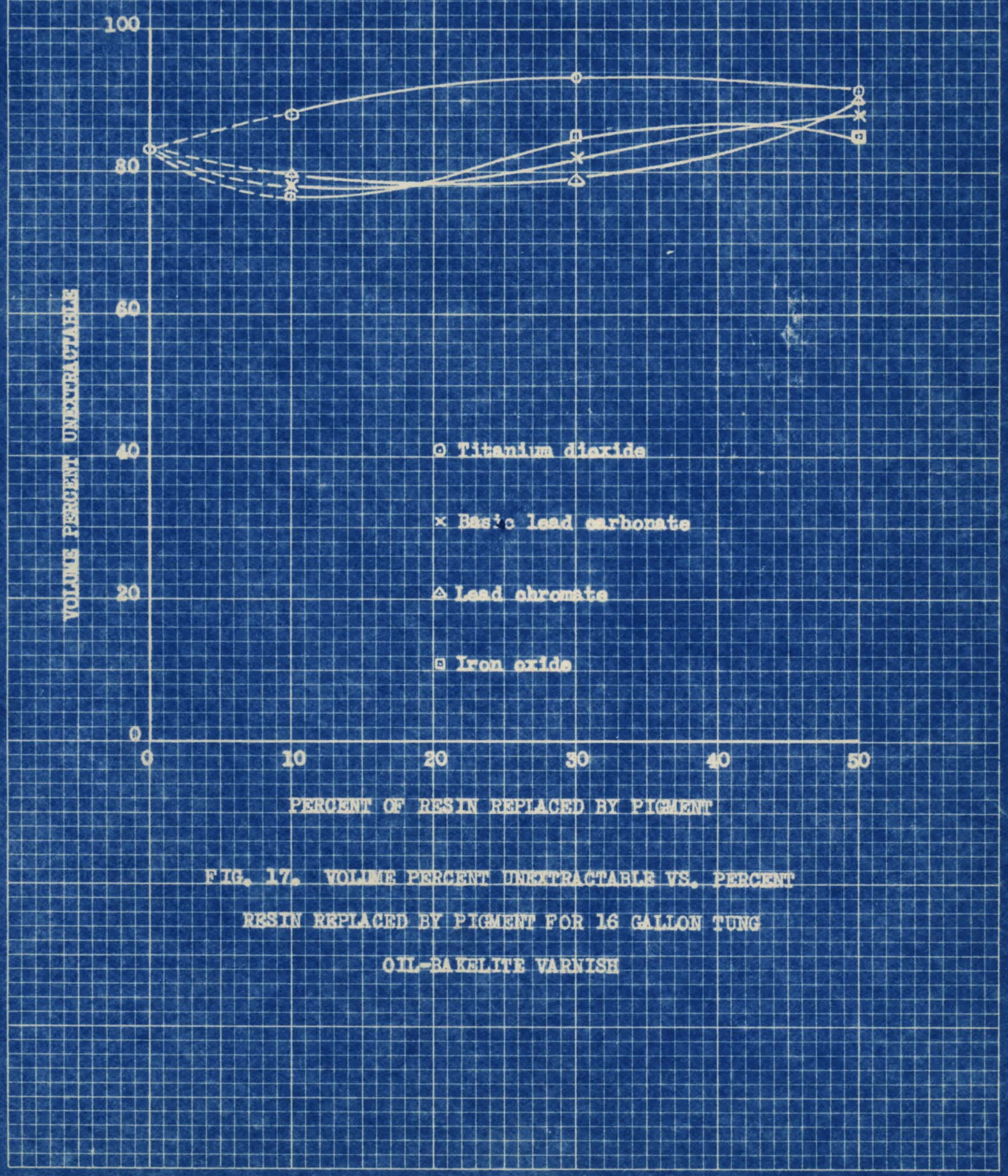




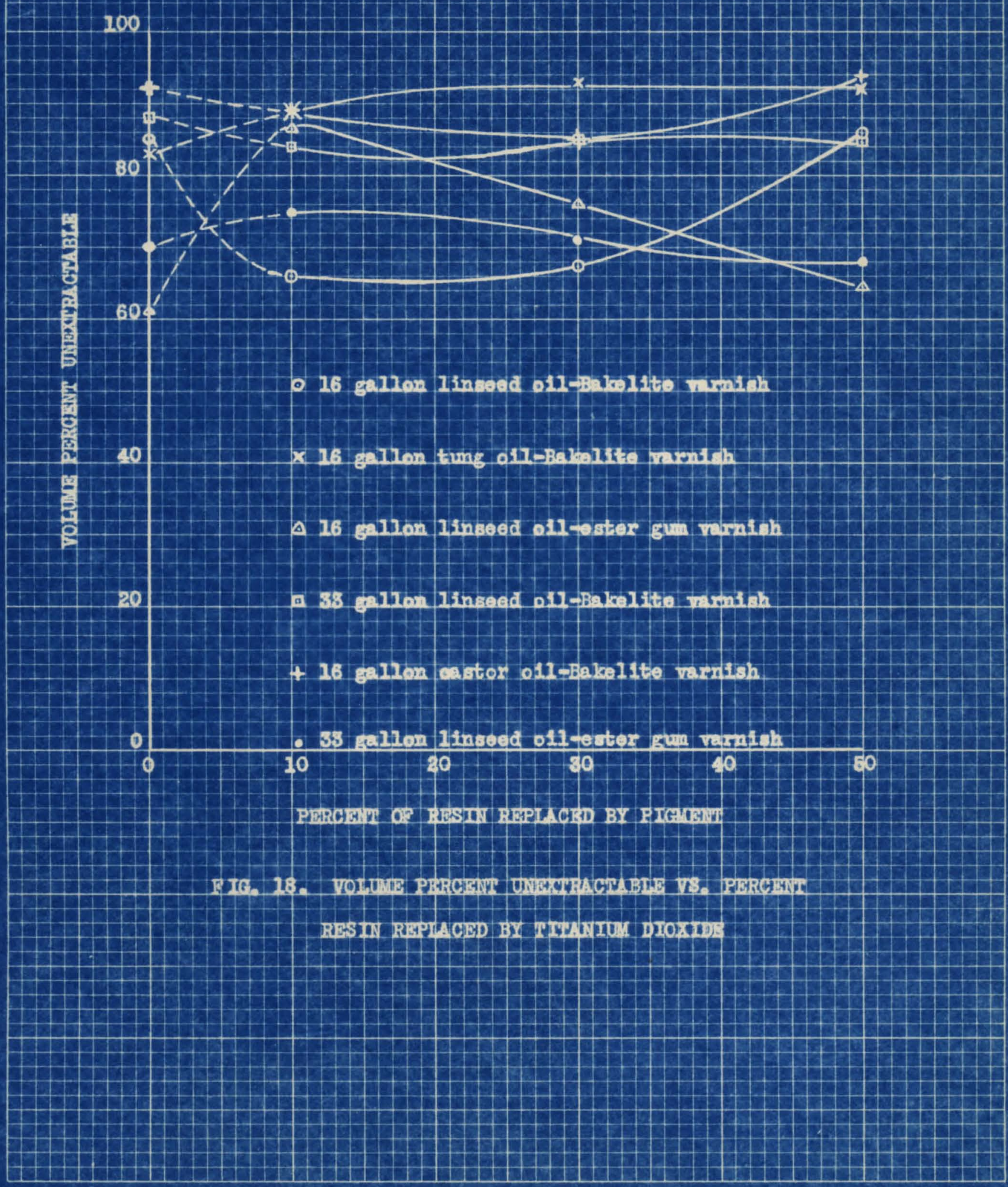




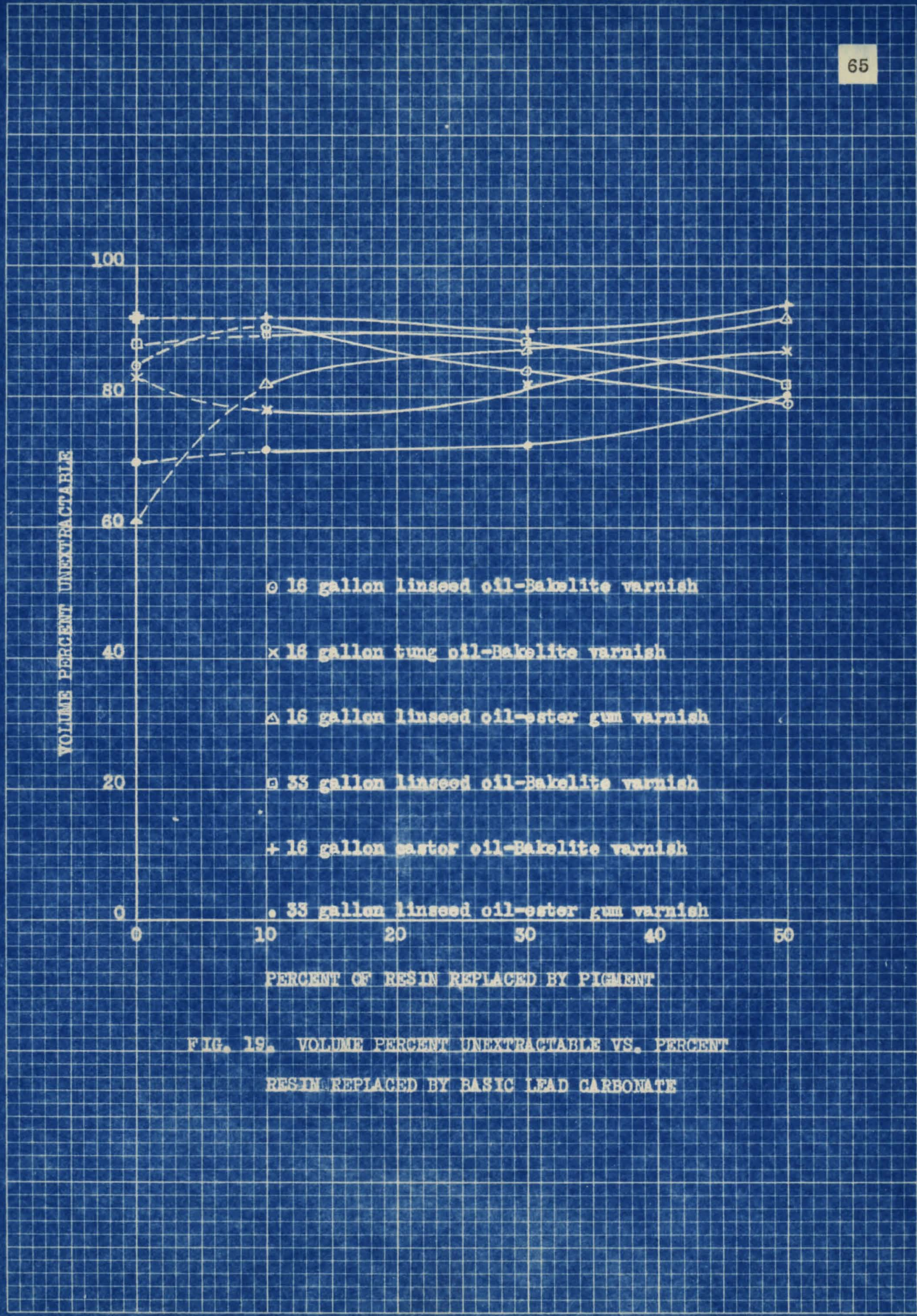




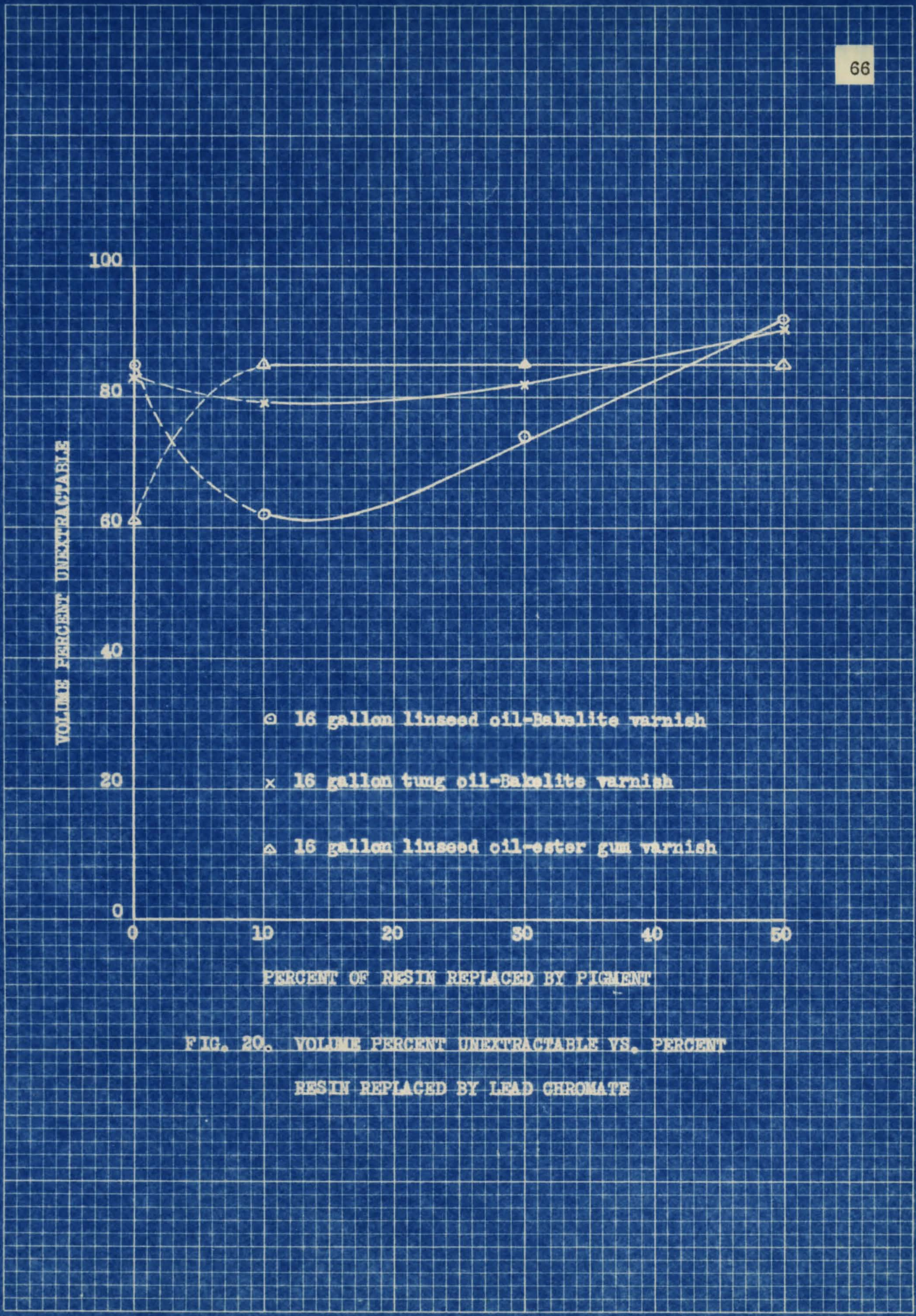







erreote are gute variod.

In oompurting the poroent longation and tenclle

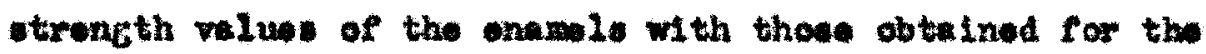
clear veralshe, the following gonerel efrecte are noted.

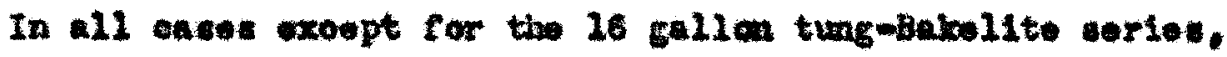
the tens1le otrangth of the enamel Alum are lese then that of the don varalahov. In every ofes the peroent elongetion

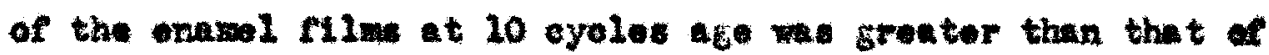
the olear varnithes.

Prow these bearvation it seens thet the polymer networke of the onamol f1.me are Intarlinked with lous cosploxity and thorefore are leas rigld than the correspending varniah 11 ma.

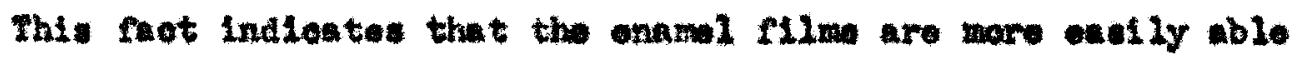
to adjuet themelves to the internal and oxtemal atreses that

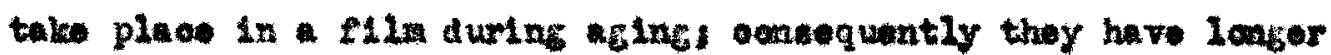
11fe. Oa the other hand, tho vamieh flime are mare rosiotent to any moleouler rearrangowent then the correspondsng onamel flin, as indientod from tho tonsilo otrongth dath. 


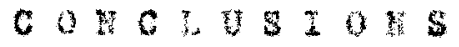

A

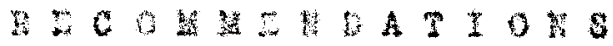


The result of the reanroh were opordinated wh those of the proceding anveatigatlan to form the folloring conolusi met

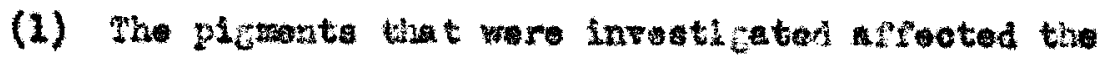
polymariestion rate of the vamishe only to stril extant.

(2) Thon the plcments ware subetstuted for reain in assounte leas than fifty pareant the polymot contant at fallure wa

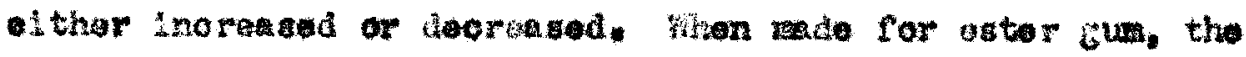
oubetltution brought about incraes in the falluremolymar in

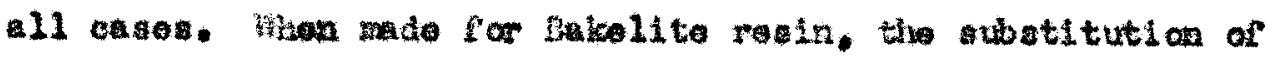
pignont brough about a decrease in the polymar content at fallure with two oxotions. Those exooptions aro tltaniun

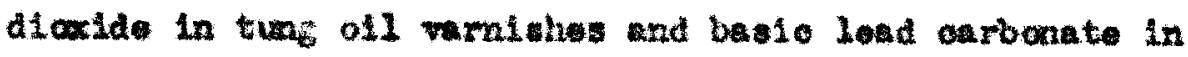
15nesed oll vamishes.

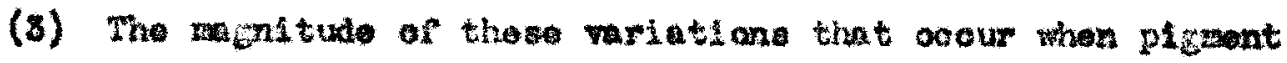

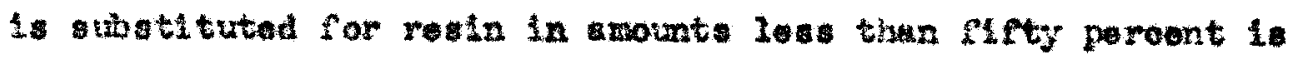

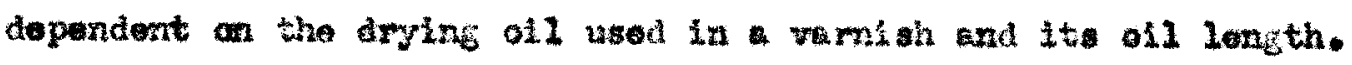

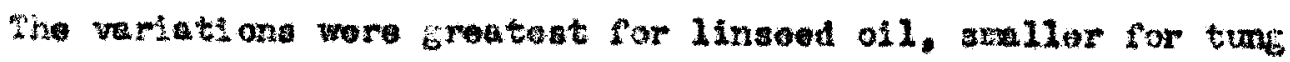

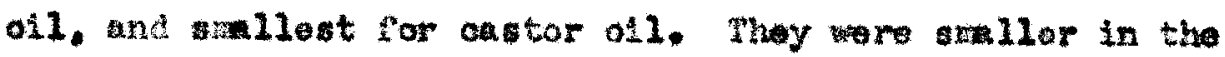
Laner ofl vaminas.

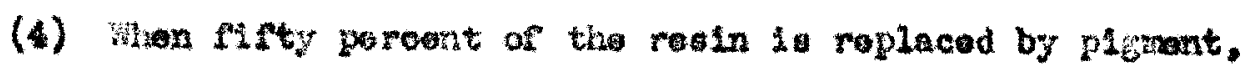

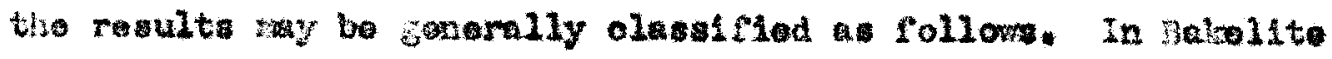
vamithes (typion of Inaclule typo rean) the austitution can

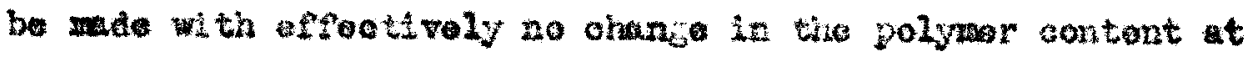




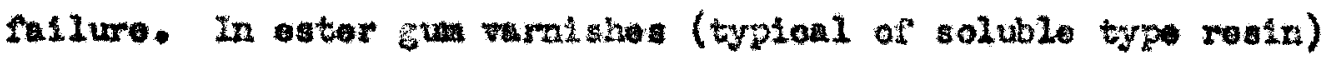

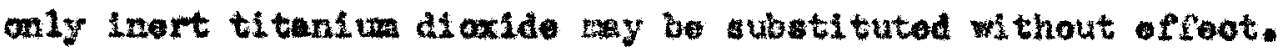

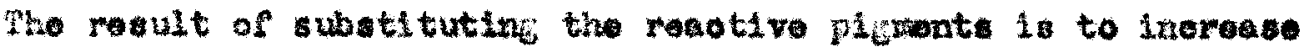
the polymar catent at filure into the range of the ineoliblo rosin type vamishes and onawiso.

(5) The floooulating tendenoy of cadnum yollow pligront

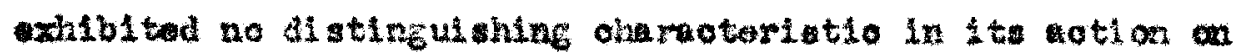

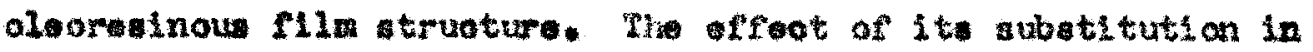
the cormations we sidatar wo that of tho other plements.

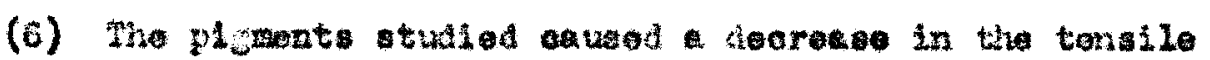

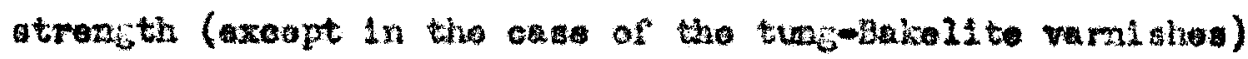
aocompanded by an inorata In the porcent longetion of the

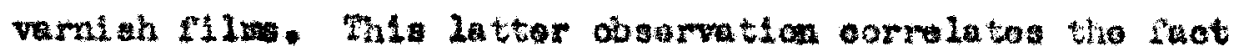

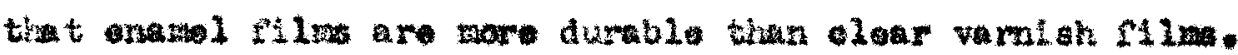

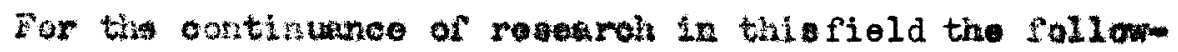

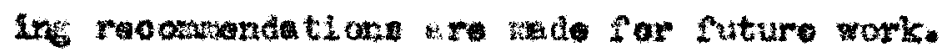

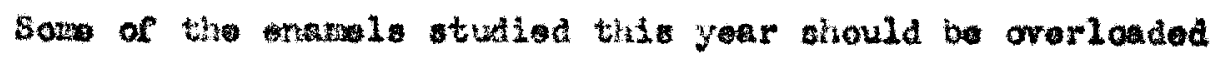
with plownt, ovon to the point of repleclns anemindred poroont of the resin with pligent. De the other hand, samples oontainine

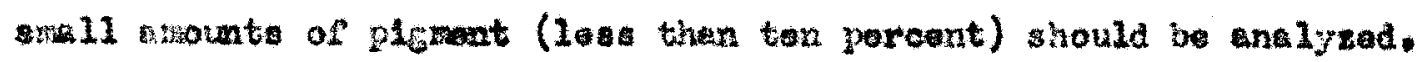

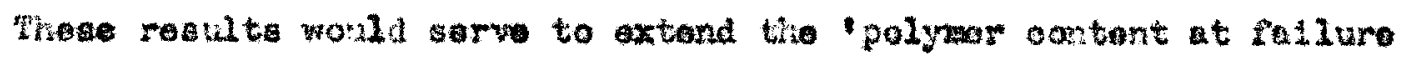

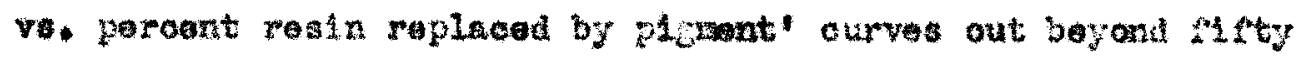

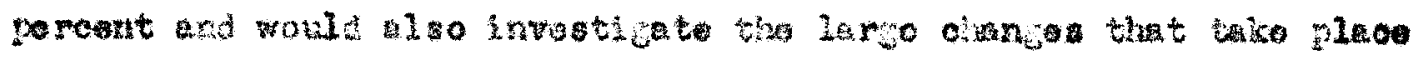




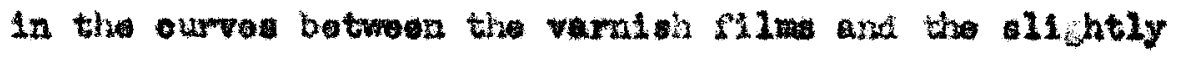

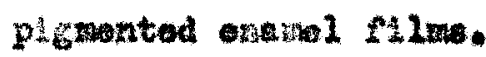

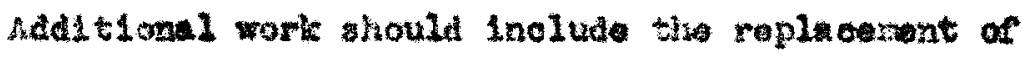

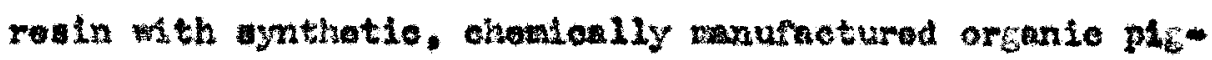
wonte. Av atarting point one plutent thould bo chosen stom

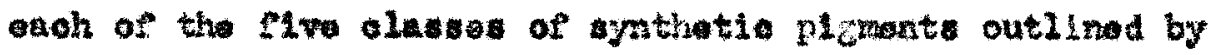

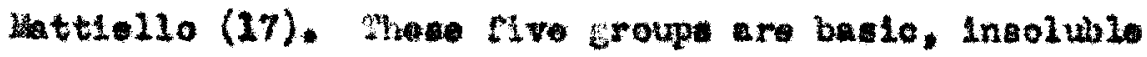
axo, solublo azo, coudengation acld, anthraguanom and rat.

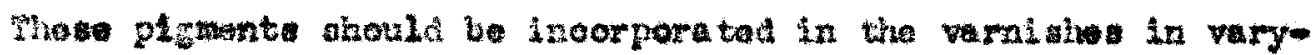

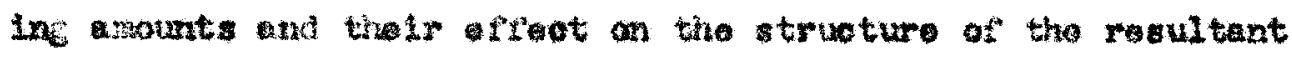
P11ms trudiod.

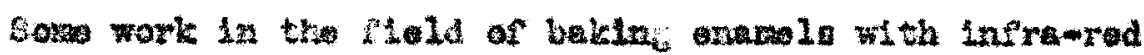

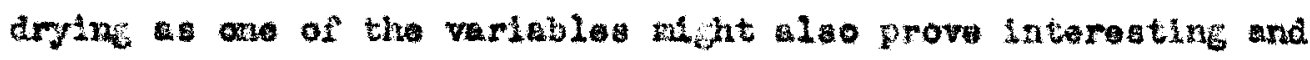
Intorative. 
A P I I I I 
LA

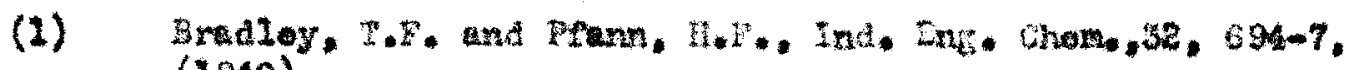
$(1940)$.

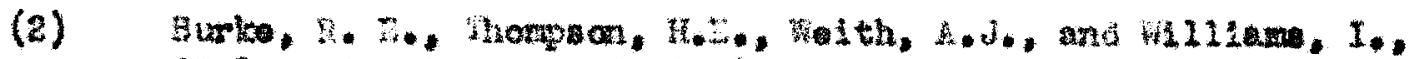

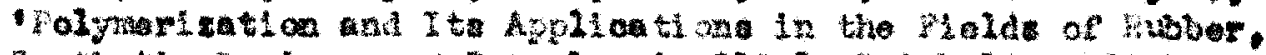

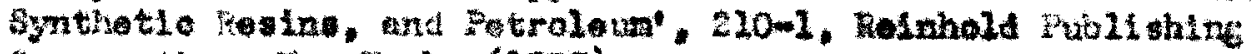
Corport on, tow York, (1937).

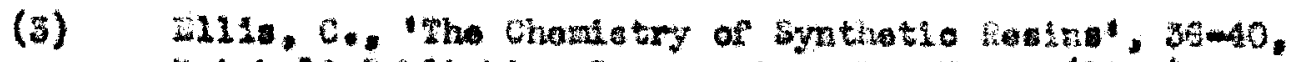

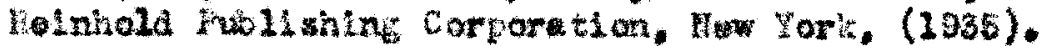

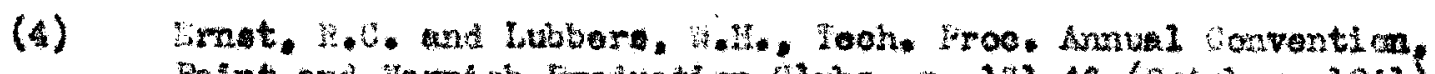

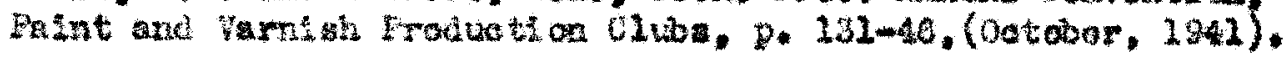

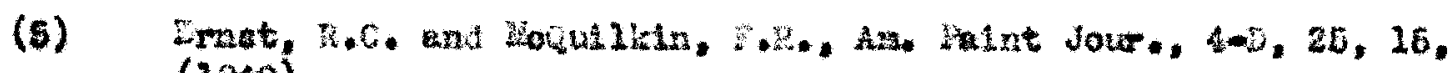
$(1900)$.

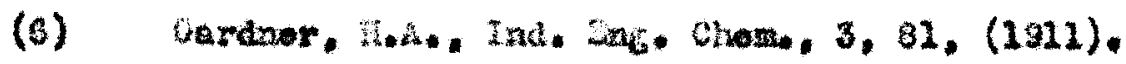

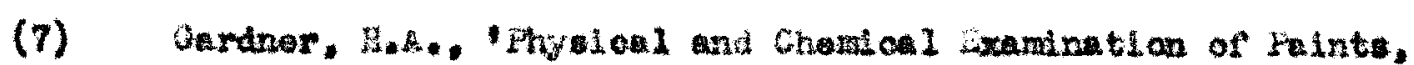

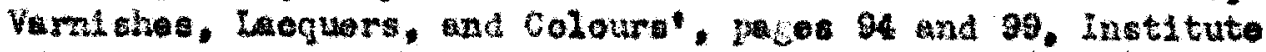

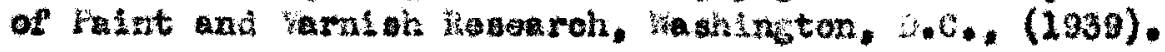

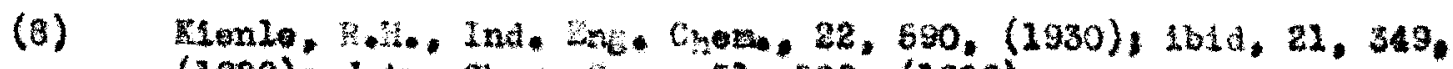
(1929): J.ka. Crata soc, 51,509, (1029).

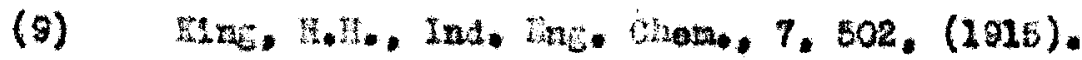

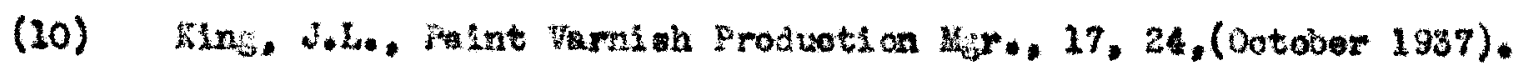

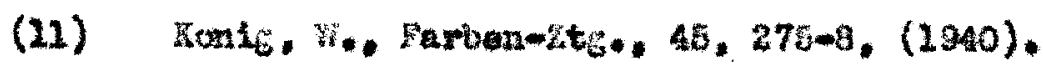

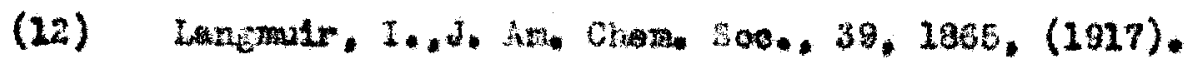

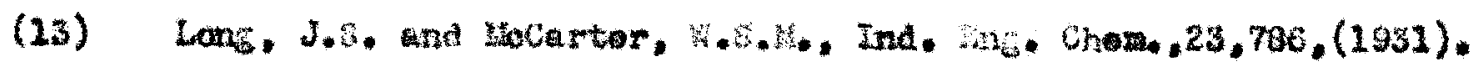

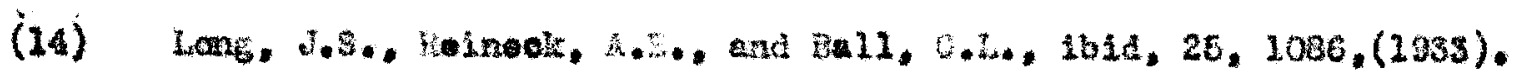

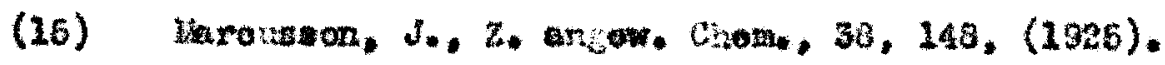

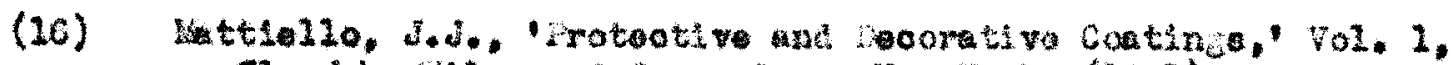

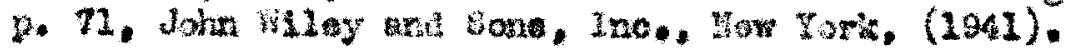

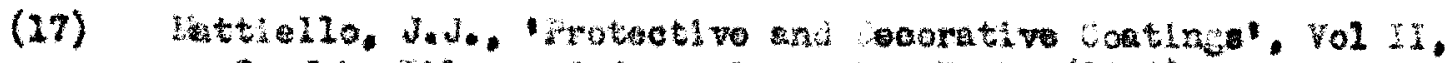

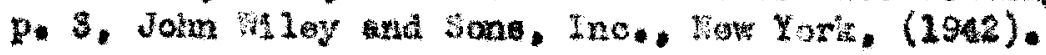




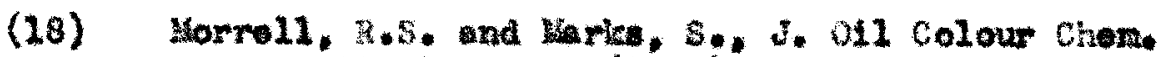
A6800, 12, 184-202, (1920).

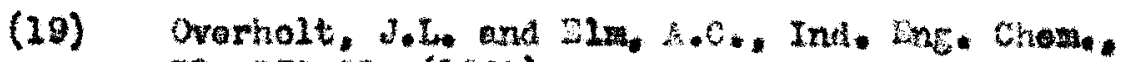
32. 379-33, (1940).

(20) $154,32,1340-51,(1940) *$

(21) ibtd, 33, 668-60, (1941).

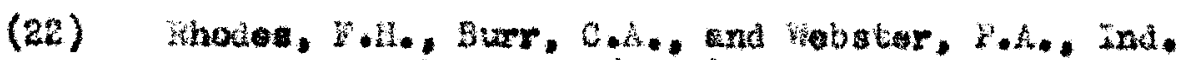
sae. Orant, $10,960,(1924)$.

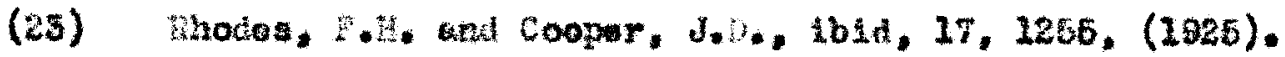

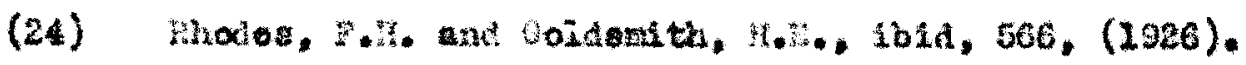

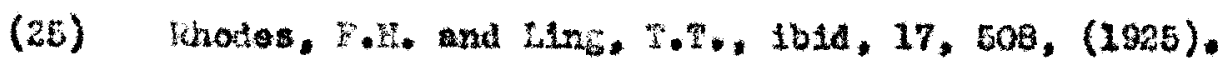

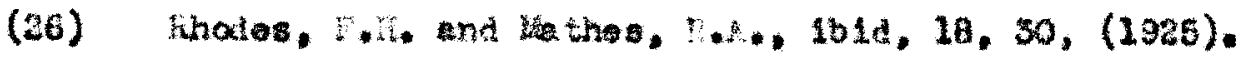

(27) Bhodas, P.t. and Van Virt, $A, 3,161 d, 15,1135,(1923)$.

(28) Fose, C, and Solloy, $5,5,1311,28,115,(1956)$.

(29) Sabin, . . 1b1d, 3, 31, (2911).

(30) shuey, $, ., \ldots, 161 d, 32,021-30,(1240)$.

(31) Temon, c., sat rime, 


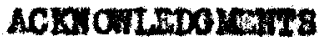

Th wuther whes to thask the Federat 1 on of Palnt and Varnich Produstion Clubs for the grant that made this invostigation posible. He eapoolally whes to axprese hil indobtodnoss to the Federation Soholorahtp comattes, Woure, K.J.How, Charman, J. S, Long, P.O.Blackere, E. J. Cole, H. A. Oardner, and $0 . \mathrm{H}$. Priest Jr.

Ho also wante to expreas his approoletion to Dr. J.S.Lang. H. Otto J. LLIet1, and H. H. L. Beaket, mambers of the Loulav111. Production Clb, who serred as lool oomaltes on researoh for the foderutt on and supervised this problem, and to Hr. Jame I. Stevens wo asalisted in the experimontal work. and to the following ocmpenies for thelr dontion of marlales

Charles R. Lang Jr. Company, Lous oville Zentuoly Color and Chemiond Company. Loular1210

Devo and Faynolde Company, Ino., Loulaville 
$\forall I t$

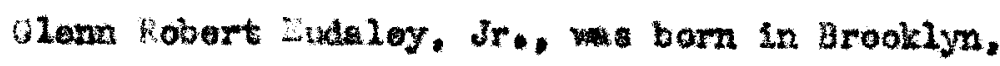
Wh Tork, on July 11, 1920, the con of Glann Ludaloy ant Bentrice Jomson. Ho recelved ha primary oducation in the public schools of Loutaville, his fandily havine moved to Lowiaville before he was of wohol aco. Hits acondary eduention rocolved at Loufstille the wh Sohool.

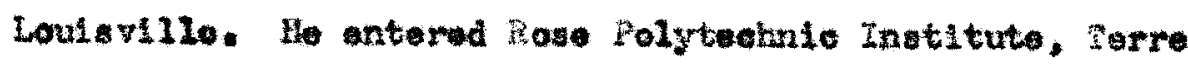

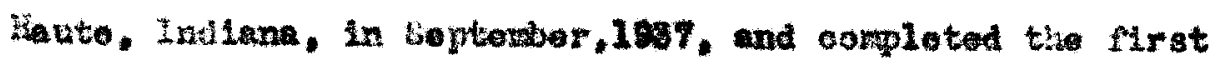
your of his enginesring course before enterine the speed Retantlete sohool of the Detwersty of Loulsv1110. Here he comploted the romindnis thre years of hat under-graduto

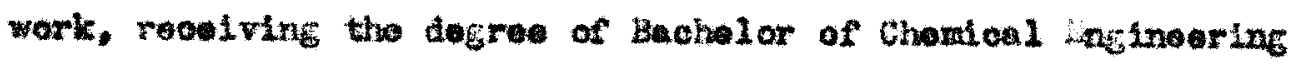
In sutut, 1961. Ho reodred the degree of hater of Chentoal tonerangers in 1042 .

S. Wudteley was amarded the Federation of peint and

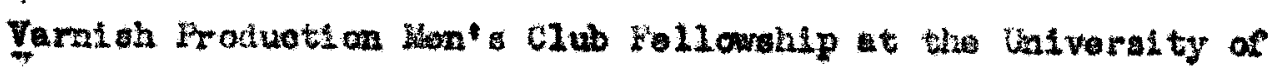
Louldvillo for tha joar 1942-1942, and upon completion of this work was onployed by the Taxae Gryeny at Port Arthur, Taxea.

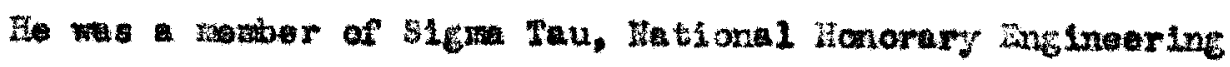
Fratemity. servine se seoretary of oncoron chapter for the year

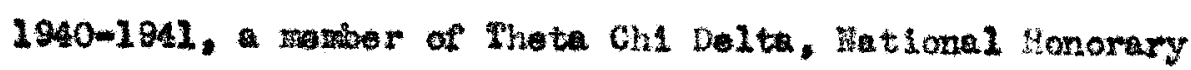


Chowatry eratemity, a waber of hlpha Tau Omege,

Tational social Fratornity, a momor of Fyramid

Praternity, a loal sooial fratarity for ancigooring

studente, and a momer of the Iniversity of Lousivile

student Chaptre of the Amorican Institute of ohondeal

inglneers. 